University of Tennessee College of Law

Legal Scholarship Repository: A Service of the Joel A. Katz Law Library

UTK Law Faculty Publications

Winter 2018

\title{
The Organization of Islamic Cooperation's (OIC) Response to Sexual Orientation and Gender Identity Rights: A Challenge to Equality and Nondiscrimination Under International Law
}

Robert Blitt

Follow this and additional works at: https://ir.law.utk.edu/utklaw_facpubs

Part of the Law Commons

Recommended Citation

Blitt, Robert, "The Organization of Islamic Cooperation's (OIC) Response to Sexual Orientation and Gender Identity Rights: A Challenge to Equality and Nondiscrimination Under International Law" (2018). UTK Law Faculty Publications. 173.

https://ir.law.utk.edu/utklaw_facpubs/173

This Article is brought to you for free and open access by Legal Scholarship Repository: A Service of the Joel A. Katz Law Library. It has been accepted for inclusion in UTK Law Faculty Publications by an authorized administrator of Legal Scholarship Repository: A Service of the Joel A. Katz Law Library. For more information, please contact eliza.boles@utk.edu. 


\title{
The Organization of Islamic Cooperation's (OIC) Response to Sexual Orientation and Gender Identity Rights: A Challenge to Equality and Nondiscrimination Under International Law
}

\begin{abstract}
Robert C. Blitt*
This article further explores the Organization of Islamic Cooperation's ("OIC") peculiar understanding of international nondiscrimination and equality norms by considering how it engages with sexual orientation and gender identity ("SOGI") rights. After reviewing the OIC's historical approach to human rights and its ambivalent acceptance of universality, the article focuses on the organization's contemporary effort to promote the "protection of the family" within the international human rights arena. This campaign-driven by the OIC's belief that "Islamic family values" are under legal and intellectual assaultchampions only those families premised on marriage between a man and a woman. Consequently, families built around lesbian, gay, bisexual, transgender and intersex ("LGBTI") and other relationships risk exposure to inequality, discrimination and denial of existing rights under international human rights law.

OIC advocacy of protection of the family, however, is by no means the only area where the organization has sought to exclude the LGBTI community. Nor does the OIC's position in the narrow context of family reflect a complete accounting of its motives for opposing recognition of SOGI rights. Accordingly, the article proceeds to consider how other core components of the OIC's human rights platform and accompanying rationales manifest hostility even to the slightest hint of SOGI rights recognition. As will be demonstrated, this hostility cuts across a wide swath of human rights issues, ranging from extrajudicial killings to the right to health. And while by no means reflective of the sole possible interpretation of Islamic norms, the OIC continues to press its view as authoritative, generating significant controversy and fallout, particularly at the United Nations.
\end{abstract}

\footnotetext{
* Professor of Law, University of Tennessee College of Law. The author is grateful to Jorge Contesse, Ronke Odumosu-Ayanu, Noah Bialos, Sarah Dadush, Christiane Ahlborn, Bart Smit Duijzentkunst, and the other participants who braved an epic snowstorm to provide helpful feedback on an earlier draft of this article at the 2017 ASIL International Organizations Interest Group Works-in-Progress Workshop. Thanks also to Nathan Golden, Amra Bašić, and the impressive team at the University of Iowa's Journal of Transnational Law \& Contemporary Problems, for their professionalism and attention to detail in readying this manuscript for publication.
} 
After highlighting the shortcomings and inconsistencies associated with the OIC's position on SOGI recognition, the article concludes by offering several recommendations. These recommendations, directed at states and civil society, outline responses to the OIC's attempt to undercut international equality and nondiscrimination norms and are intended to ensure that the principle of universality is not undermined in the formulation and enforcement of international human rights law.

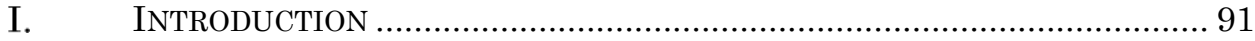

II. The Evolution OF THE OIC's APPROACH TO HUMAN RIGHTS ............. 92

A. $\quad$ The OIC's Early Engagement with Human Rights ............................ 92

B. The Cairo Declaration on Human Rights in Islam: A Fatally Flawed But Persistent First Contribution.

C. A Legacy That Persists: CDHRI as Anchor Point for OIC Human Rights Engagement .......................................................................... 97

D. Grappling with Universalism: The OIC's Shifting Take on Universal

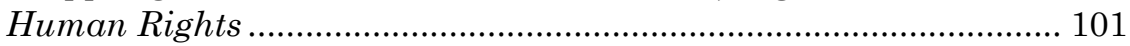

1. OIC Resolutions Betray Uneasy Relationship with Universality ... 102

2. An OIC-Sponsored Seminar on Enriching the Universality of Human Rights Falls Flat .............................................................................. 114

3. The OIC and Universality in the 21st Century .............................. 122

III. THE OIC'S CONTEMPORARY ENGAGEMENT WITH EQUALITY AND Non-Discrimination: Denial of Protection On BASIS OF SOGI .. 126

A. Protection of the Family: Nexus for Perpetuating Discrimination Against Women and on the Basis of Sexual Orientation and Gender Identity

1. The OIC's Active Emphasis on Family Values is a Recent Phenomenon

2. $\quad$ Protecting an "Ideal Family" Demands Conformity with OIC Religious Views Rather than International Reality .... 129

B. OIC Denial of SOGI Equality and Nondiscrimination Transcends Protection of the Family...

1. Multiple OIC Justifications for Rejecting SOGI Recognition Combine to Deplete Right to Highest Attainable Standard of Health

2. Rejection of SOGI Recognition: Extrajudicial Killings ..................... 148

3. Rejection of SOGI Recognition: Torture and Inhuman or Degrading

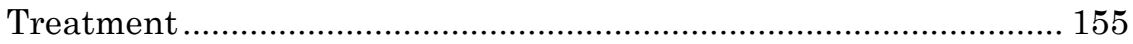

4. Rejection of SOGI Recognition: Freedom of Assembly …................. 157

C. Epicenter of the Clash: Formal UN Human Rights Council

Recognition of Sexual Orientation and Gender Identity .................. 160

1. UNHRC Resolution 17/19 on SOGI (2011) ..................................... 160

2. UNHRC Resolution 27/32 on SOGI (2014) .................................... 166

3. UNHRC Resolution 32/2 on SOGI (2016) ....................................... 169

D. $\quad$ OIC Efforts to Rollback the 2016 UNHRC SOGI Resolution ............ 176 
1. Reaction of the 43d OIC Conference of Foreign Ministers

2. An Eleventh-Hour Effort to Derail the SOGI Resolution at the UN

General Assembly

3. OIC Ministerial Conference on Strengthening Marriage and Family

Institution and Preserving its Values in Member States................. 181

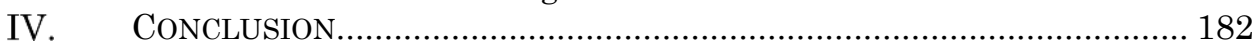

\section{INTRODUCTION}

This article is the second in a two-part series exploring the Organization of Islamic Cooperation's ("OIC") understanding of the international human rights norms that govern the principles of nondiscrimination and equality. The first article, ${ }^{1}$ focusing on women's rights, established a baseline for the OIC's relationship with the principles of equality and nondiscrimination by examining how the organization's founding Charter and subsequent policy statements have come to frame these principles. It then proceeded to assess how the OIC's contemporary understanding of these principles manifests itself in international debates surrounding women's rights, as well as in the organization's effort to advocate on behalf of its amorphous concept of "Islamic family values." From the OIC's perspective, its undefined religious values necessitate state protection because the family unit's identity and existence are under legal and intellectual threat. Accordingly, any governmental measures adopted to protect the family should take precedence over the right of women to equality.

The OIC's emphasis on "protection of the family" has even more farreaching consequences; it operates as a nexus for discrimination, and the inequality that flows from the OIC prioritizing this value is by no means limited to harming the rights of women. Therefore, the present article picks up where the first left off, by examining the discriminatory effects of the OIC's peculiar understanding of nondiscrimination and equality norms in the context of sexual orientation and gender identity ("SOGI"). After reviewing the OIC's historical approach to human rights and its ambivalent acceptance of universality, the article uses the organization's promotion of protection of the family as a pivot point to shift focus from women's rights to the OIC's engagement with SOGI rights. As this paper will demonstrate, because the OIC's framing of "Islamic family values" extends protection of the state only to those families that satisfy a narrow definition of "family"-namely one premised on marriage between a man and a woman-its invocation necessarily obviates equal protection for families built around lesbian, gay, bisexual, transgender and intersex ("LGBTI") and other relationships. Imposing this protection likewise operates to invalidate any recognition of SOGI-related individual rights founded on equality and nondiscrimination.

1 See generally Robert C. Blitt, Equality and Nondiscrimination Through the Eyes of an International Religious Organization: The Organization of Islamic Cooperation's (OIC) Response to Women's Rights, 34 WIS. INT'L L.J. 755 (2017). 
At the same time, advocacy of protection of the family is not the only area where the OIC has insisted on a narrow framing of equality and nondiscrimination principles that excludes the LGBTI community. Nor is the OIC's motivation in this context reflective of a complete accounting of its rationale for opposing recognition of SOGI rights. Accordingly, after discussing developments related to protection of the family, the article considers how other core components of the OIC's human rights platform and their related justifications manifest hostility to recognition of SOGI rights. As will be demonstrated, this antipathy cuts across a wide swath of human rights issues, ranging from extrajudicial killings to the right to health.

After highlighting the shortcomings and inconsistencies associated with the OIC's position on SOGI recognition, the article concludes by offering several recommendations aimed at developing appropriate responses to the OIC's attempt to undercut international equality and nondiscrimination norms. Prioritizing these recommendations-as well as those offered previously within the context of women's rights-is especially critical. The failure to decisively confront the OIC's ongoing efforts to promulgate a distorted and religiously-restrictive framing of equality and nondiscrimination serves to undermine the spirit of universality reflected in the Universal Declaration of Human Rights' ("UDHR") grundnorm that "[a]ll human beings are born free and equal in dignity and rights." ${ }^{2}$ But more urgently still, allowing the perpetuation and expansion of the OIC's vision risks legitimizing real and ongoing rights violations against LGBTI persons, women, and others.

\section{The Evolution OF THE OIC'S APPROACH TO HUMAN Rights}

\section{A. The OIC's Early Engagement with Human Rights}

Consisting of 57 member states, the OIC describes itself as "the second largest inter-governmental organization after the United Nations." ${ }^{3}$ As the self-proclaimed "collective voice of the Muslim world," the OIC's raison d'être is "safeguard[ing] and protect[ing] the interests of the Muslim world." ${ }^{4}$ In asserting this mandate, the OIC also embodies the only contemporary intergovernmental organization that claims to unify its member states around the common banner of a single religion. ${ }^{5}$

${ }^{2}$ G.A. Res. 217 (III) A, art. 1 (Dec. 10, 1948) [hereinafter UDHR].

${ }^{3}$ History, ORG. ISLAMIC COOPERATION, https://www.oic-oci.org/page/?p_id=52\&p_ref=26\&lan=en (last visited Nov. 21, 2018).

${ }^{4} \mathrm{Id}$. While the OIC may be one of the most vocal and prominent voices of the Muslim world, as this article demonstrates, its claim to represent the "collective voice" of the Muslim world is contested.

${ }^{5}$ Abdel Monem Al-Mashat, The Organization of the Islamic Conference and the Post Cold War Era, in The Organization of THE Islamic CONFEREnCE IN A CHANGing World 147, 150 (El Sayed Selim ed., 1994); see also IOANA CISMAS, RELIGIOUs ACTORS AND INTERNATIONAL LAW 239, 241 (2014) (describing the OIC as "the sole inter-governmental actor to display religious contours and to claim the role of interpreter of human rights in the context of Islam" and as an organization where "the role of religion is intertwined with political goals"). 
The OIC's founding 1972 Charter evidenced little specific regard for human rights. The Charter's preamble generally reaffirmed a "commitment to the U.N. Charter and fundamental Human Rights" 6 and asserted as one of the organization's stated objectives "to endeavor to eliminate racial segregation, discrimination and to eradicate colonialism in all its forms." 7 At the same time, the Charter's only reference to equality related to equality between member states of the organization in the context of national sovereignty, ${ }^{8}$ rather than to equality among individuals.

As the organization began holding regular meetings and developing a work program, a small number of resolutions emerging from its Council of Foreign Ministers ("CFM") sessions and Islamic Summit conferences (attended by heads of state) made explicit reference to human rights. Few, if any, of these sought to elaborate on the human rights obligations of OIC member states or on the organization's understanding of these norms. Rather, these early resolutions evidenced the OIC's willingness to invoke human rights as a basis for condemning non-OIC states for perceived human rights violations. For example, already in 1973, the CFM appealed

to peace-loving states, [and] religious and international authorities to use their good offices with the Philippines government in order to halt the campaigns of violence against the Muslim community in the Philippines and ensure their safety and the basic liberties guaranteed by the Universal Declaration on Human Rights and their country's Constitution $\ldots 9^{9}$

In 1979, the OIC's CFM established a consultative commission of Muslim experts "to draw up a document on Human Rights" based on the outcome of an OIC seminar that occurred the previous year. ${ }^{10}$ One year later, the CFM opted to revise this first effort and tasked the experts with "preparing an alternative document" based on Member States' observations. ${ }^{11}$ In 1983, the CFMexpressing its conviction "that the individual's enjoyment of freedom, justice \& equal opportunities is commensurated with the genuine authenticity of any sound community [and] ... [r] ecognizing the close relationship between human rights and world peace"12_unanimously adopted the Dhaka Declaration on Human Rights in Islam. This brief seven-paragraph declaration set out a

\footnotetext{
${ }^{6}$ OIC, Charter of the Islamic Conference, pmbl. (Mar. 4, 1972) [hereinafter 1972 OIC Charter].

${ }^{7}$ Id. art. II(A)(3).

${ }^{8} I d$. art. II(B)(1).

9 OIC Res. 4/4, If 4 (Mar. 24, 1973). Similarly, the second Islamic Summit in 1974 "[c]ondemn[ed] Israel's violation of human rights in the occupied Arab territories." OIC Res. 1/2-IS, I 1(8) (Feb. 22-24, 1974).

10 OIC Res. 9/10-C, ๆ 1 (May 8-12, 1979).

${ }^{11}$ OIC Res. 19/11-C (May 17, 1980).

12 OIC Res. 3/14-ORG (Dec. 6-11, 1983).
} 
religiously-infused and nebulous vision of human rights that affirmed, among other things:

"the cultural and historical role of the Islamic Ummah ... [is] to contribute to the effort of mankind to assert human right [sic] to protect man from exploitation and persecution, and to affirm his freedom and right to a dignified life in accordance with the Islamic Shariah";

"Fundamental rights and freedom according to Islam are an integral part of the Islamic faith and that no one shall have the right to abolish ... violate or ignore them"; and

"all human beings from [sic] one family whose members are united by their subordination to Allah and, being the descendants of Adam, all men are equal in dignity end [sic] basic duties and responsibilities without any discrimination on account of race, colour, language, religion, sex, political opinion, social status or other considerations . . .."13

OIC heads of state subsequently identified the Dhaka Declaration on Human Rights in Islam as "embod[ying] the preamble" of a more detailed final document on "Human Rights in Islam," and called for further study. ${ }^{14}$ Member states would go on to grapple with the substance of this final document over the following six years, ${ }^{15}$ before ultimately approving the Cairo Declaration on Human Rights in Islam (“CDHRI") in 1990. ${ }^{16}$

During this protracted negotiation period, however, the OIC continued to expand its reliance on human rights as a tool for framing the organization's resolutions targeting non-member states. In 1986, for example, the OIC urged its members to "exert utmost efforts" on non-member states to demand that "oppressed Islamic minorities" be treated "on the basis of equality and non-discrimination and ... [be] grant[ed] ... all their legitimate rights,

${ }^{13}$ OIC, Fourteenth Islamic Conference of Foreign Ministers, The Dhaka Declaration on Human Rights in Islam (Dec. 6-11, 1983), http://ww1.oic-oci.org/english/conf/fm/14/14\%20icfm-orgen.htm\#THE\%20DHAKA\%20DECLARATION\%20ON\%20HUMAN\%20RIGHTS\%20IN\%20ISLA M.

${ }^{14} \mathrm{OIC}$, Final Communiqué of the Fourth Islamic Summit Conference, II 28 (Jan. 16-19, 1984), http://ww1.oic-oci.org/english/conf/is/4/4th-is-sum.htm.

${ }_{15}$ See generally OIC Res. 2/16-ORG, ๆ 28 (Jan. 6-10, 1986) (calling for "[m]ember States to send their final observations on the Draft Document on Human Rights in Islam to the General Secretariat.”); OIC Res. 44/17, ๆ 1 (Mar. 21-25, 1988) (“[r]ecognizing the importance of issuing a Document on Human Rights in Islam" and referring "the draft Document on Human Rights in Islam to the Ministers of Justice in the Member States for study and finalization."); OIC Res. 41/18, I 1 (Mar. 13-16, 1989) (urging "Member States to send their observations on the draft Document on Human Rights in Islam to the OIC General Secretariat as soon as possible.").

${ }_{16}$ OIC Annex to Res. 49/19, art. 5 (Jul. 31-Aug. 5, 1990) [hereinafter CDHRI]; see also World Conference on Human Rights, Contribution of the Organization of the Islamic Conference, U.N. Doc. A/CONF.157/PC/62/Add.18 (June 9, 1993). 
including their religious and cultural rights." 17 Subsequent renewal of the OIC's resolution on Muslim communities in non-Muslim states elaborated on its human rights-based approach. By 1990, the resolution text invoked "international conventions and agreements particularly those agreements which call for the observance of Human Rights and political, social, cultural, economic and religious freedoms." 18 These resolutions further urged OIC members "to make ... [non-OIC states with Muslim minority communities] grant these Islamic communities all their civil and religious rights and treat them with equity in accordance with the international law and criteria relating to human rights and basic freedoms." 19

\section{B. The Cairo Declaration on Human Rights in Islam: A Fatally Flawed But Persistent First Contribution}

The OIC's recognition of the need to engage more substantively in shaping the contours of international human rights emerged at least in part because the field had become an increasingly significant and strategic arena for international engagement. Already in 1982, the OIC resolved to "cooperate more closely [with the UN in the] common quest for solutions to world problems, such as issues related to international peace and security ... fundamental human rights and the establishment of a New International Economic Order." 20 As noted above, in adopting the Dhaka Declaration, the organization similarly acknowledged "the close relationship between human rights and world peace." 21 Ultimately, the OIC's framing of the CDHRI-its long-negotiated final human rights declaration-attested to the newfound strategic importance the organization ascribed to human rights as a currency of international relations. ${ }^{22}$ The Declaration's preamble confirmed the OIC's "[w]ish] to contribute to the efforts of mankind to assert human rights." 23 Further, it signaled the organization's recognition of "the utmost importance [of] human rights at the international level [and at] the level of relations

${ }^{17}$ OIC Res. 29/16, ๆ 2 (Jan. 6-10, 1986).

18 OIC Res. 42/19, pmbl. (Jul. 31-Aug. 5, 1990).

${ }^{19} I d$. 11.

${ }^{20}$ OIC Res. 20/13, ๆ 4 (Aug. 22-26, 1982).

${ }^{21}$ OIC Res. 3/14-ORG, supra note 12.

${ }^{22}$ Others have observed this phenomenon elsewhere. In the case of the Gulf Cooperation Council's (GCC) member states,

[t]he trend for increased ratifications of UN human rights treaties . . . show that the GCC states consider UN human rights treaty ratification an important aspect of integrating into the international system and view remaining outside of the human rights system as costly for their standing in the international community.

Bas,ak Cali et al., Big Promises, Small Gains: Domestic Effects of Human Rights Treaty Ratification in the Member States of the Gulf Cooperation Council, 38 HUM. RTS. Q. 21, 56 (2016).

${ }^{23}$ CDHRI, supra note 16 , pmbl. 
among the OIC ... resulting from the current interactions in the international arena." ${ }^{24}$ To be certain, the CDHRI embodied a significant organizational milestone. In addition to culminating a lengthy negotiation process, ${ }^{25}$ the Declaration remedied the OIC Charter's dearth of human rights content by setting out "general guidance for Member States in the field of human rights." 26 Still, as "general guidance," the CDHRI-despite fourteen years of OIC drafting and the coincident growth of international recognition surrounding the import of human rights law-signaled no more than an organizational declaration rather than a binding treaty. In other words, the CDHRI did not formally generate legal obligations for member states or provide means for its enforcement. ${ }^{27}$

Although the CDHRI in principle is non-enforceable, two significant realities persist. First, a review of the Declaration's substantive provisions raises genuine concern for compliance with universal human rights norms. And second, despite the CDHRI's status as "general guidance," it remains central to the OIC's approach to human rights and indicative of the types of binding norms to which the organization aspires. With respect to the first point, the Cairo Declaration variously lessens, qualifies, or altogether omits recognition of fundamental rights protections already enshrined under the Universal Declaration of Human Rights ("UDHR") and other related international human rights instruments. ${ }^{28}$ Specifically regarding equality and nondiscrimination, article 1 of the CDHRI provides that "men are equal in terms of basic human dignity and basic obligations and responsibilities, without any discrimination on the grounds of race, colour, language, sex, religious belief, political affiliation, social or other considerations." 29 To be fair, this provision encouragingly leaves open the possibility of acknowledging that discrimination impacting human dignity might flow from "other considerations" besides those specifically enumerated. ${ }^{30}$ However, it more glaringly signals a decisive retreat from the sweeping promise enshrined forty years earlier under the UDHR - a promise not merely of equal dignity but of equal rights for all. Articles 1 and 2 of the UDHR provide that "[a]ll human beings are born free and equal in dignity and rights," and that "[e]veryone is

${ }^{24}$ OIC Res. 37/20, ๆ 4 (Aug. 4-8, 1991).

${ }^{25}$ The CFM's Political Committee stated "that, after 14 years of deliberations and studies relative to the document on Human Rights in Islam, it had arrived at a consensus on the final draft of the document to be entitled "The Cairo Declaration of Human Rights in Islam." OIC, Nineteenth Islamic Conference of Foreign Ministers, Report of the Political, Legal and Information Affairs Committee (Jul. 31-Aug. 5, 1990), http://ww1.oic-oci.org/english/conf/fm/19/19\%20icfm-politicalen.htm\#REPORT\%20OF\%20THE\%20POLITICAL,\%20LEGAL\%20AND\%20INFORMATION\%20 AFFAIRS

${ }^{26}$ OIC Res. 49/19, ๆ 1 (Jul. 31-Aug. 5, 1990).

${ }^{27}$ Still, the OIC appeared to want it both ways. See infra Part II(C).

${ }^{28}$ See UDHR, supra note 2, art. 1; G.A. Res. 2200A (XXI) (Mar. 23, 1976) [hereinafter ICCPR].

${ }^{29}$ CDHRI, supra note 16 , art. 1(a).

${ }^{30} I d$. 
entitled to all the rights and freedoms set forth in [the UDHR], without distinction of any kind, such as race, colour, sex, language, religion, political or other opinion, national or social origin, property, birth or other status." 31

One might make the case that article 1 of the CDHRI represents a salvageable departure point for human rights engagement. But the provisions that follow make such a claim highly implausible. Among other things, the Cairo Declaration permits religion to serve as a valid basis for discrimination; ${ }^{32}$ assigns distinct rights and responsibilities on the basis of gender; 33 and restricts the rights to freedom of movement, freedom of expression, and participation in public affairs on the basis of undefined sharia law. ${ }^{34}$ The CDHRI's penultimate incompatibility with international human rights norms is confirmed by the document's final provisions. These provisions make all rights contingent upon ambiguous religious law and require that any interpretive guidance for the document itself occur within an Islamic vacuum, detached from the relevant international human rights instruments. ${ }^{35}$

\section{A Legacy That Persists: CDHRI as Anchor Point for OIC Human Rights Engagement}

Some observers have ventured that, with the passage of time, the OIC has backed away from the CDHRI and now tacitly downplays its relevance. ${ }^{36}$ This perceived shift in approach may be driven, at least in part, by the justifiable criticism leveled by human rights advocates against the CDHRI ${ }^{37}$ or the OIC's desire to present a more "mainstream" approach to rights. In either instance,

31 UDHR, supra note 2, arts. 1-2 (emphasis added).

${ }^{32}$ CDHRI, supra note 16 , art. 5 . Article 5 allows for the imposition of marriage restrictions based on religion: "Men and women have the right to marriage, and no restrictions stemming from race, colour or nationality shall prevent them from enjoying this right." Id.

${ }^{33}$ Under article 6, women's equality is limited to "human dignity" and "[t]he husband is responsible for the support and welfare of the family"; under article 12, freedom of movement and related rights appear to be limited to men. $I d$. arts. 6,12 .

${ }^{34} I d$. arts. 12, 22-23 (limiting free movement rights to undefined "framework of Shari'ah," and minimizing government obligations where asylum "motivated by an act which Shari'ah regards as a crime"; limiting rights to expression, advocacy and information on basis of undefined sharia "principles" and "norms"; and limiting right to assume public office on basis of undefined "provisions of Shari'ah").

35 Id. arts. 24-25. Articles 24 and 25 provide: "All the rights and freedoms stipulated in this Declaration are subject to the Islamic Shari'ah," and "[t]he Islamic Shari'ah is the only source of reference for the explanation or clarification of any of the articles of this Declaration." Id.

${ }^{36}$ See, e.g., Turan Kayaoglu, The Organization of Islamic Cooperation: Politics, Problems, AND POTENTIAL 99 (2015) (claiming that "most OIC staff largely ignore the declaration in their discussions of Islam and human rights").

37 See, e.g., Yakin Erurk (Special Rapporteur), Report of the Special Rapporteur on Violence against Women, Its Causes and Consequences on Intersections Between Culture and Violence Against Women, U.N. Doc. A/HRC/4/34 (Jan. 17, 2007), http://www.refworld.org/docid/461e2c602.html. 
the second critical reality that characterizes the CDHRI must not be obfuscated. Namely, the OIC continues to validate the document-including its rejection of universality in favor of religious relativism - as a legitimate basis for limiting existing international human rights commitments and for demarcating the substance of its own more recent human rights initiatives. To this point, suggesting that the CDHRI no longer informs the OIC's perspective on human rights or that its relevancy is otherwise diminished ignores numerous warnings to the contrary.

As early as 1991, the OIC heads of state urged member countries to consider becoming party to the UN Convention on the Rights of the Child, but only "in so far as the stipulations contained in it are compatible with the Declaration of Human Rights in Islam." 38 Since this time, the OIC has not taken any formal measures to repeal the Cairo Declaration or otherwise distance itself from the norms espoused therein. ${ }^{39}$ Instead, as recently as 2014, the OIC Secretary General asserted that "[t]he Cairo Declaration on Human Rights in Islam embodies the OIC's most complete statement on human rights in Islam as seen by the Member States." 40 More than this, a clearly discernable pattern in the OIC's recent activities confirms its

38 OIC, Final Communiqué of the Sixth Islamic Summit Conference, ๆ 55 (Dec. 9-11, 1991) (emphasis added).

39 A 2015 OIC resolution welcomed the Gulf Cooperation Council's (GCC) Human Rights Declaration and instructed its own human rights commission to "[take] the lead from this forward looking document ... to review [the CDHRI] against existing universal human rights instruments and make suggestions for its improvement, if and where necessary.” OIC Res. 1/42-Leg, I 12 (May 27-28, 2015). All six GCC members are OIC member states. No outcome from this review was available when this article went to press. For the text of the GCC Declaration, see The Cooperation Council for the Arab States of the Gulf, GCC Human Rights Declaration (Dec. 9, 2014), http://www.gcc-sg.org/en-

us/CognitiveSources/DigitalLibrary/Lists/DigitalLibrary/Human\%20Rights/1453192982.pdf. Pegging an organization's human rights aspirations to those of the GCC is inherently problematic. According to one scholarly assessment, the GCC brings:

together six of the least politically liberalized countries in the Arab world ...
The form and content of [its human rights] initiatives ... suggest a continued
demand for symbolic measures to alleviate domestic and international
pressure rather than measures that effectively support political reforms for the
liberalization and modernization, if not democratization, of incumbent regimes
in accordance with a global governance script.

Vera van Hüllen, Just Leave Us Alone: The Arab League and Human Rights, in Governance TRANSFER By REgional ORGanizations: PATChing Together a Global SCRIPT 125, 140 (Tanja A. Börzel \& Vera van Hüllen, eds. 2015). Two years after the GCC adopted its Human Rights Declaration, Amnesty International accused its member states of having "appalling human rights records" and sweeping the issue of human rights "under the carpet." GCC Summit: Systematic Clampdown on Freedom of Expression in Gulf, AMNESTY INT'L (Dec. 5, 2016), https://www.amnesty.org/en/latest/news/2016/12/gcc-summit-systematic-clampdown-on-freedomof-expression-in-gulf/.

${ }^{40}$ Press Statement, Statement of His Excellency Iyad Ameen Madani, Secretary General of the Organisation of Islamic Cooperation at the Fourth Session of the OIC Independent Permanent Human Rights Commission (IPHRC), (Feb. 2, 2014) [hereinafter Statement of Iyad Ameen Madani]. 
unabated advocacy of the flawed vision originally espoused by the CDHRI, whereby universal human rights norms are subverted in name of ill-defined religious imperatives.

Three recent milestones in the OIC's institutional development are useful for illustrating the extent of the entrenchment and durability of the CDHRI's vision. The first is evidenced in the OIC's 2005 Ten Year Program of Action, a document intended to set out the challenges facing the Muslim world and the "means to address them." 41 This action plan called on the organization to consider "establishing an independent permanent body to promote human rights in the Member States, in accordance with the provisions of the [CDHRI]." 42 Further, it affirmed the idea of establishing a parallel Islamic rights regime, also "in accordance with . . . the [CDHRI]." ${ }^{33}$ The Ten Year Program also sought to give life to the CDHRI's rights-limiting approach by conditioning "the advancement of women in Muslim societies," and member state adherence to the UN Convention on the Elimination of all Forms of Discrimination against Women, ${ }^{44}$ on the basis of undefined "Islamic values of justice and equality." 45

The OIC's overhauled organizational Charter provides the second milestone. This updated Charter, adopted in 2008, signaled a partial break from the past by more explicitly incorporating human rights language. Still, this shift was saddled by other competing provisions that attenuate the document's potential impact. For example, the 2008 Charter newly established the promotion and protection of "human rights and fundamental freedoms including the rights of women, children, youth, elderly and people with special needs," as an explicit OIC objective. ${ }^{46}$ However, the document also retained an overriding preoccupation with member state equality rather than expressly acknowledging equality as a human right ascribed to individuals. ${ }^{47}$ The

${ }^{41}$ Ten Year Programme of Action to Meet the Challenges Facing the Muslim Ummah in the 21st century, 3d Extraordinary Session of the Islamic Summit Conference, intro. (Dec. 7-8, 2005) [hereinafter OIC Ten Year Program].

42 Id. art. 1(VIII)(2) (emphasis added). The OIC established this body-the Independent Permanent Human Rights Commission-in 2011. See Statute of the OIC Independent Permanent Human Rights Commission, OIC Doc. OIC/IPCHR/2010/STATUTE (2010) (originally adopted by OIC Res. No. 2/38-LEG On the Establishment of the OIC Independent Permanent Human Rights Commission (IPHRC), 38th Session of the Council of Foreign Ministers, OIC (June 28-30, 2011)) [hereinafter IPHRC Statute].

${ }^{43}$ OIC Ten Year Program, supra note 41, art. 2(VI)(3).

${ }_{44}$ Id. art. 2(VI)(1); see G.A. Res. 34/180, Convention on the Elimination of All Forms of Discrimination Against Women (Dec. 18, 1979) [hereinafter CEDAW].

${ }^{45}$ OIC Ten Year Program, supra note 41, art. 2(VI)(1); see also Blitt, supra note 1 (discussing how sharia-based reservations to CEDAW compromise women's rights by distorting international equality and nondiscrimination norms).

${ }^{46}$ OIC, Charter of the Organisation of Islamic Cooperation, art. 1(14), (Mar. 14, 2008) [hereinafter 2008 OIC Charter].

${ }^{47} I d$. art. 2(2). 
Charter's continuing omission of explicit support for the principle of nondiscrimination, 48 and the introduction of new objectives-including the safeguarding of undefined "Islamic family values" 49 _ generate further human rights concerns, particularly in the context of this article.

Furthermore, like the CDHRI, the 2008 Charter's effort to endorse the promotion and protection of human rights is detached from recognized international norms. Rather than endorse an international baseline, member states only "undertake [that] they shall be guided and inspired by [undefined] noble Islamic teachings and values." 50 Beyond this undefined touchstone, member states need only promote human rights and fundamental freedoms to the extent it is "in accordance with their constitutional and legal systems." 51 In other words, the revised OIC Charter perpetuates-à la CDHRI-the use of undefined religious norms to measure human rights compliance. Moreover, it disconnects itself from international standards by explicitly asserting domestic law as supreme over existing international human rights norms. ${ }^{52}$

Finally, the 2008 Charter, acting on the Ten Year Program's call to establish an OIC human rights body, ${ }^{53}$ officially blessed the Independent Permanent Human Rights Commission ("IPHRC") as a new OIC organ. ${ }^{44}$ The Charter also elucidated the Commission's mandate to promote "rights enshrined in the organisation's covenants and declarations [presumably including the CDHRI] and in universally agreed human rights instruments, in conformity with Islamic values." 55 The IPHRC statute, enacted several years after the 2008 Charter, makes plain the Commission's raison d'être is grounded in the CDHRI. ${ }^{56}$ By requiring the IPHRC to promote the rights enshrined in the CDHRI, the OIC effectively blanketed the new Commission in the Cairo Declaration's relativistic shadow and signaled its desire to use the Commission to further shape the CDHRI's aspirations into legally binding norms.

Any lingering doubt over the continuing relevancy of the CDHRI in the IPHRC's mandate is put to rest by examining OIC Resolution No. 1/38-Leg on

\footnotetext{
48 See 1972 OIC Charter, supra note 6, pmbl., art. II(A)(3).

492008 OIC Charter, supra note 46, art. 1(14).

${ }^{50} I d$. art. 2.

${ }^{51} I d$. pmbl. ("We the Member States of the Organisation of the Islamic Conference, determined . . . to promote human rights and fundamental freedoms, good governance, rule of law, democracy and accountability in Member States in accordance with their constitutional and legal systems.”).

${ }^{52}$ Blitt, supra note 1, at 772 .

${ }^{53}$ OIC Ten Year Program, supra note 41, § 1(VIII)(2).

542008 OIC Charter, supra note 46, art. 5, 15.

${ }^{55} \mathrm{Id}$. art. 15.

${ }^{56} I d$. (recalling the CDHRI and provides that the IPHRC "shall promote the . . rights enshrined in the organisation's covenants and declarations and in universally agreed human rights instruments, in conformity with Islamic values."); IPHRC Statute, supra note 42, pmbl.
} 
Follow Up and Coordination of Work on Human Rights. ${ }^{57}$ Passed alongside the IPHRC statute in 2011, this resolution reaffirms the OIC's commitment to prioritizing the enactment of Islamic human rights covenants 58 and the continued centrality of the CDHRI to this end. ${ }^{59}$ The resolution's preamble posits that the promotion and protection of human rights can occur only "with due regard" to the Cairo Declaration. ${ }^{60}$ It also endorses the ongoing "formulation of a set of Islamic covenants on human rights" as a way "to promote and protect human rights." ${ }^{61}$ Finally, the resolution's operative section further promulgates "the right of States to adhere to their religious, social, and cultural specificities." 62

\section{Grappling with Universalism: The OIC's Shifting Take on Universal Human Rights}

As noted above, much of the impetus for the CDHRI flowed from the OIC's recognition that human rights had rapidly become a burgeoning field with significant implications for diplomacy and public relations. ${ }^{63}$ As such, the organization needed to develop a common policy position from which it could seek to impact the evolving international discourse. While the CDHRI may reflect a certain measure of achievement in this regard, its disconnect from universality has also left the OIC with an unwieldy and problematic foundation for international engagement that has yet to be repaired.

Overarching claims of compatibility between the OIC's undefined notions of sharia and "Islamic values" on one hand, and universal human rights norms on the other, might withstand superficial probing. But when examined in the context of human rights in practice-in areas ranging from freedom of

${ }^{57}$ OIC Res. 1/38-LEG (Jun. 28-30, 2011).

58 This priority is also noted above in the context of the OIC's 2005 Ten Year Program. See OIC Ten Year Program, supra note 41.

${ }^{59}$ OIC Res. 1/38-LEG, supra note 57, pmbl.

${ }^{60} I d$.

${ }^{61} I d$.

62 Id. art. 4. But see World Conference on Human Rights, Vienna Declaration and Programme of Action, $§ 1(5)$, (Jun. 25, 1993) [hereinafter VDPA] (requiring “[s]tates, regardless of their political, economic and cultural systems, to promote and protect all human rights and fundamental freedoms").

${ }^{63}$ See generally Robert C. Blitt, Who Will Watch the Watchdogs? Human Rights Nongovernmental Organizations and the Case for Regulation, 10 BuFF. HuM. RTS. L. REV. 261, 261-398 (2004); Thomas Buergenthal, The Normative and Institutional Evolution of International Human Rights, 19.4 HUM. RTS. Q., 703, 703-723 (1997). 
expression ${ }^{64}$ to women's rights ${ }^{65}$ to SOGI rights-such claims expose compatibility cracks with universality, whether on the grounds of vagueness or outright conflict with international norms. ${ }^{66}$

To date, the organization has failed to repeal or amend the religiouslyprioritized provisions of the CDHRI, and instead has characterized the Declaration as "embod[ying] the OIC's most complete statement on human rights . . . ." 67 This has complicated the organization's quest for greater influence in the human rights arena, where the universality of human rights is sacrosanct. Understanding this tension and the OIC's failure to resolve it, is critical to unpacking the organization's rejection of equality and nondiscrimination norms regarding SOGI rights.

\section{OIC Resolutions Betray Uneasy Relationship with Universality}

The OIC's own resolutions serve as one indicator of the organization's uneasy relationship with human rights universality. Starting in 1991, the OIC Conference of Foreign Ministers began issuing two annual resolutions relating to human rights. The first addressed general coordination and cooperation on human rights, and the second focused specifically on follow up to the CDHRI. The preamble to the human rights coordination resolution noted that the "increasing importance of human rights throughout the world calls for further intensification of the efforts of the Islamic Ummah and Islamic organizations...to take appropriate initiatives at the national, regional and international level." It further reasoned "that recent trends among the O.I.C. to protect the collective interest of the Member States in the process of ever-changing international developments requires closer coordination to strengthen the common cultural and social values in

${ }^{64}$ Robert C. Blitt, The Bottom Up Journey of "Defamation of Religion" from Muslim States to the United Nations: A Case Study of the Migration of Anti-Constitutional Ideas, 56 STUD. L. POL. \& SOC'Y 121, 155 (2011) (arguing that a "closer look at the OIC's advocacy favoring a ban on defamation of religion reveals an approach that embodies not one but several anti-constitutional ideas that operate to foreclose the principles of nondiscrimination and equality and undercut universal rights to freedom of expression and freedom of religion or belief . ...").

65 See Blitt, supra note 1.

${ }^{66}$ For example, Jordan has long maintained its reservations to CEDAW art. 16 "because it is incompatible with the provisions of Islamic law, the Shari'a ... [o]ver and above this legal reason ... we may add the fact that husband and wife have different responsibilities in the framework of a single family." Comm. on the Elimination of Discrimination Against Women, Consideration of Reports Submitted by States Parties Under Article 18 of the Convention on the Elimination of All Forms of Discrimination Against Women, $\mid$ 302, U.N. Doc. CEDAW/C/JOR/5 (Sept. 24, 2010). Most recently in 2016, Jordan rejected the CEDAW Committee's recommendation to withdraw its article 16 reservations, claiming "the issue of lifting the reservations has to be dealt with very sensitively and gradually, in a manner that balances the promotion of women's human rights with the obligation to reject whatever contradicts the provisions of Islamic Shariah." Comm. on the Elimination of Discrimination Against Women, Consideration of Reports Submitted by States Parties Under Article 18 of the Convention, I 108, U.N. Doc. CEDAW/C/JOR/6 (June 25, 2015).

${ }^{67}$ Statement of Iyad Ameen Madani, supra note 40. 
international arenas." 68 However, the resolution's preamble omitted any mention of the UDHR or universality, and instead invoked only the OIC Charter and the CDHRI as the basis for promoting human rights. Although the original 1991 human rights coordination resolution also exhibited a dearth of operative content, this changed dramatically in 1993, coincidentally the year of the UN's landmark World Conference on Human Rights. ${ }^{69}$

The OIC's intent to weigh in at 1993 UN World Conference was no secret. Already in 1991, the OIC's resolution on CDHRI follow up invited "Member States to coordinate their positions ..." at the world conference on the basis of the CDHRI's guidelines. ${ }^{70}$ As part of this advance effort, OIC member states participated in preparatory regional meetings for Africa and Asia, ${ }^{71}$ as well as meetings organized by the League of Arab States ("LAS"). ${ }^{72}$ OIC members represented more than half of the 42 states participating in the African regional meeting in November 1992. ${ }^{73}$ The Tunis Declaration, the African region's outcome document, reaffirmed the commitment to the principles contained in the UDHR and the International Covenant on Civil and Political Rights ("ICCPR"). It also acknowledged that the "universal nature of human rights is beyond question; their protection and promotion are the duty of all States, regardless of their political, economic or cultural systems." 74 The Tunis Declaration's embrace of universal human rights, however, came with a caveat: "no ready-made model can be prescribed at the universal level since the historical and cultural realities of each nation and the traditions, standards and values of each people cannot be disregarded." 75

68 OIC Res. 22/6 (Dec. 9-11, 1991).

69 See World Conference on Human Rights, U.N. Hum. RTS. OfFICE OF High Comm'R, http://www.ohchr.org/EN/AboutUs/Pages/ViennaWC.aspx (last visited Nov. 21, 2018). (noting that the World Conference closed with the consensus adoption of the Vienna Declaration and Programme of Action, "the culmination of a long process of review and debate over the current status of human rights machinery in the world."). There was no OIC Conference of Foreign Ministers meeting in 1992.

${ }^{70}$ OIC Res. 37/20, supra note 24 ฯ 3.

${ }^{71}$ See Ineke Boerefijn, Vienna World Conference on Human Rights, in MAX PLANCK ENCYCLOPEDIA OF PUBLIC INTERNATIONAL LAW (2007) (noting that in preparation for the World Conference, regional conferences took place in Africa, Asia, and Latin America. No official regional meeting was held in Europe, though the Council of Europe organized an unofficial interregional meeting).

72 Profile: Arab League, BBC NEws (Aug. 24, 2017), https://www.bbc.com/news/world-middle-east15747941.

${ }^{73}$ See World Conference on Human Rights, Report of the Regional Meeting for Africa of the World Conference on Human Rights, U.N. Doc. A/CONF.157/AFRM/14 (Nov. 2-6, 1993) [hereinafter The Tunis Declaration].

${ }^{74}$ Id. ๆ $1-2$.

${ }^{75} I d$. I 5. Although the Tunis Declaration itself omits a specific assertion to the effect that the principle of non-interference applies to human rights scrutiny, one of the resolutions adopted at the regional meeting "[s]tresses that respect for ... human rights and fundamental freedoms also require the commitment of all Governments to respect fully . . . the principles of national sovereignty, territorial integrity and non-interference in the internal affairs of States.” Id. ๆ 6. 
Several months later, the eleventh session of the LAS Standing Committee on Human Rights "warmly welcomed" the Tunis Declaration "since it [met] Arab demands." " At the same meeting, the LAS approved its own "plan of action for the agenda of the World Conference on Human Rights . . ."77 This plan omitted a clear endorsement of universality. Instead, it emphasized "respect for national sovereignty and ... the principle that human rights should not be used as an excuse for interference in the internal affairs of States." 78 Further, the LAS plan emphasized the need to respect "the cultural and religious identity of peoples and nations when formulating and implementing international conventions on human rights." 79 The same meeting also called on LAS member states (all of them OIC members) "to ensure that ... [its plan of action] is included in the final document to be issued at the Asian Regional Meeting" and "in the final document of the [World] Conference." 80

In March 1993, Asian states held their own regional meeting in Bangkok. OIC members accounted for over one-third of the participating states. ${ }^{81}$ The meeting's concluding document, the Bangkok Declaration, intended to reflect "the aspirations and commitments of the Asian region." 82 Among other things, the Bangkok Declaration's operative section prioritized "the principles of respect for national sovereignty and territorial integrity as well as noninterference in the internal affairs of States, and the non-use of human rights as an instrument of political pressure." ${ }^{3}$ After establishing these priorities, the Declaration acknowledged that "while human rights are universal in nature, they must be considered in the context of a dynamic and evolving process of international norm-setting, bearing in mind the significance of national and regional particularities and various historical, cultural and religious backgrounds." 84

The Bangkok Declaration's assertive “double qualification" of universality-invoking non-interference to foreclose external scrutiny and imposing "national and regional particularities and various historical, cultural

${ }^{76}$ Comm'n on Human Rights, Further Promotion and Encouragement of Human Rights and Fundamental Freedoms, Including the Question of Programme and Methods of Work of the Commission, U.N. Doc. E/CN.4/1993/90 (Feb. 12, 1993).

77 Id. Annex III ("Preparation of ideas and final plan of action for the agenda of the World Conference on Human Rights to be held in June 1993.”).

${ }^{78} \mathrm{Id}$. Annex III 93.

${ }^{79}$ Id. Annex III $\mid 6$.

${ }^{80} \mathrm{Id}$. at 7.

${ }^{81}$ See World Conference on Human Rights, Report of the Regional Meeting for Asia of the World Conference on Human Rights, U.N. Doc. A/CONF.157/PC/59 (April 7, 1993).

$82 I d$. at 3.

${ }^{83} \mathrm{Id}$. at 4.

${ }^{84} I d$. at 5 . 
and religious backgrounds" as a filter on human rights content-was not without controversy. Many observers, including Asian NGOs, were surprised by "the bold opposition to universal human rights contained in the Declaration, made on the grounds that human rights as such do not accord with "Asian values." 85 These NGOs proffered their own parallel declaration at the regional meeting that dramatically diverged from the governmental vision. The Bangkok NGO Declaration, submitted by the Coalition for Peace and Development "on behalf of all NGO participants in the Asia-Pacific NGO Forum," 86 asserted that the principle of universality effectively foreclosed the possibility that human rights advocacy could be deemed as an encroachment upon state sovereignty. Further, while embracing the notion of pluralism, the NGO Declaration forcefully rejected the possibility of justifying cultural practices that derogated from universally accepted human rights. ${ }^{87}$

One scholar has observed that the regional declarations from Tunis and Bangkok "made clear that the [World Conference scheduled for Vienna] would be filled with tensions and that the universality of human rights would be challenged." ${ }^{8}$ In raising this challenge, however, the declarations diverged appreciably in both posture and substance. In the end, despite the Bangkok Declaration's controversial content, the OIC enthusiastically adopted its approach to universality over the more mildly-worded Tunis Declaration. Meeting shortly after release of the Bangkok Declaration, the OIC's Conference of Foreign Ministers issued an unusually long human rights coordination resolution, boasting an extensive operative section. ${ }^{89}$

${ }^{85}$ Joanne Bauer, The Bangkok Declaration Three Years After: Reflections on the State of the AsiaWest Dialogue on Human Rights, Hum. RTS. Dialogue 1, 4 (1996), https://www.carnegiecouncil.org/publications/archive/dialogue/1_04/articles/518; see also Conor Gearty, Asian Values, China and Human Rights, RTs.' Future, 5, http://therightsfuture.com/wpcontent/uploads/2010/11/The_Rights_Future_CT5_Asian_Values.pdf (noting that this hostility included “dismiss[ing] even home-grown [Asian] NGOs as western meddling in disguise."); see also Pat Walsh, The Road to Vienna Went Through Bangkok (June 2013), http://home.patwalsh.net/wpcontent/uploads/The-road-to-Vienna.pdf. But see Michael W. Dowdle, How a Liberal Jurist Defends the Bangkok Declaration, in Negotiating Culture AND Human Rights 126, 144, 152 (Lynda S. Bell et al., eds., 2001) (arguing that the Bangkok Declaration's formulation is "wholly consistent with a conception of rights that enjoys much purchase in the West", but also conceding, "of course, the picture I paint of the Bangkok Declaration is not necessarily the one intended by most of its drafters or its signers.").

86 U.N. Secretary-General, Bangkok NGO Declaration on Human Rights, U.N. Doc. A/CONF.157/PC/83 (Apr. 19, 1993) [hereinafter Bangkok Declaration]. A list of the dozens of NGOs participating in the regional conference, including NGOs from OIC member states, is provided at pp. 9-10. The fact that such NGOs signed onto the NGO declaration hints at the cracks in the OIC's assertion that it serves as the "collective" voice of the Muslim world. See infra text accompanying notes 144-153, 227-231, and 440-454.

87 World Conference on Human Rights, Vienna Declaration and Programme of Action, U.N. Doc. A/CONF.157/PC/83 (Apr. 19, 1993).

88 Boerefijn, supra note 71.

${ }^{89}$ Bangkok Declaration, supra note 86. The OIC's 1993 human rights coordination resolution boasts 19 operative paragraphs as compared with only five found in similar resolutions from 1991 
This unusual burst of engagement demonstrated by the OIC resolution correlates directly to the Bangkok Declaration's influence. In certain sections, the OIC resolution duplicates contentious provisions of the Bangkok Declaration. For example, it imports nearly verbatim the Bangkok Declaration's two most controversial provisions directed at non-interference and the attenuation of universality. On this latter point, the OIC resolution only deletes "national and regional particularities" in endorsing the need to contextualize human rights on the basis of "historical, cultural and religious backgrounds" (See Table 1 below).

Elsewhere in the resolution, OIC modifications to or omissions of the Bangkok Declaration's language serve to further attenuate the legitimacy and scope of universal human rights. For example, while the OIC's 1993 human rights coordination resolution does acknowledge the UDHR, it does so only in the preamble, and then, only after contextualizing the responsibility to "promote and encourage respect for human rights and fundamental freedoms" based on the OIC Charter, CDHRI, and Islamic values and teachings. 90 Moreover, unlike the Bangkok Declaration, the resolution's operative section deletes endorsements of the UDHR, the full realization of human rights, women's full equality, the human rights of vulnerable groups such as minorities, and recognition that "no violation of human rights can be justified." 91

and in subsequent years up until 2001. From 1994-2000, the OIC's human rights coordination resolution reverts to five operative paragraphs.

90 OIC Res. 41/21, ๆ 1 (Apr. 25-29, 1993).

${ }^{91}$ Compare Bangkok Declaration, supra note 86, $\llbracket \rrbracket 5,8$ with OIC Res. 41/21, supra note 90 , ๆ 2 , 5 . 
Table 1: Comparison of Select Provisions of the Bangkok Declaration (1993) and OIC Resolution on Human Rights Cooperation (1993)

\begin{tabular}{|c|c|c|}
\hline Bangkok Declaration $^{92}$ & $\begin{array}{c}\text { OIC Resolution on HR } \\
\text { Coordination }^{93}\end{array}$ & Comment \\
\hline $\begin{array}{l}\text { Preamble: Emphasizing } \\
\text { the significance of the } \\
\text { World Conference on } \\
\text { Human Rights, which } \\
\text { provides an invaluable } \\
\text { opportunity to review all } \\
\text { aspects of human rights } \\
\text { and ensure a just and } \\
\text { balanced approach } \\
\text { thereto }\end{array}$ & $\begin{array}{l}\text { Preamble: } \\
\text { Emphasizing the } \\
\text { significance of the World } \\
\text { Conference on Human } \\
\text { rights, which provides an } \\
\text { invaluable opportunity to } \\
\text { review all aspects of } \\
\text { human rights and ensure } \\
\text { a just and balanced } \\
\text { approach thereto }\end{array}$ & Verbatim. \\
\hline $\begin{array}{l}\text { Preamble: Recognizing } \\
\text { the contribution that can } \\
\text { be made to the World } \\
\text { Conference by Asian } \\
\text { countries with their } \\
\text { diverse and rich cultures } \\
\text { and traditions }\end{array}$ & $\begin{array}{l}\text { Preamble: Recognizing the } \\
\text { contribution that can be } \\
\text { made to the World } \\
\text { Conference by Islamic } \\
\text { countries on the basis of } \\
\text { the valuable guidelines } \\
\text { contained in the "Cairo } \\
\text { Declaration on Human } \\
\text { Rights in Islam" }\end{array}$ & $\begin{array}{l}\text { OIC resolution } \\
\text { modifies reference } \\
\text { to "Asian } \\
\text { countries" to } \\
\text { account for OIC } \\
\text { specific } \\
\text { contribution based } \\
\text { on CDHRI norms. }\end{array}$ \\
\hline $\begin{array}{l}\text { Preamble: Reaffirming } \\
\text { their commitment to } \\
\text { principles contained in } \\
\text { the Charter of the United } \\
\text { Nations and the } \\
\text { Universal Declaration on } \\
\text { Human Rights }\end{array}$ & $\begin{array}{l}\text { Preamble: Bearing in } \\
\text { mind the objectives of the } \\
\text { Charter of OIC and the } \\
\text { "Cairo Declaration on } \\
\text { Human Rights in Islam" to } \\
\text { promote and encourage } \\
\text { respect for human rights } \\
\text { and fundamental freedoms } \\
\text { for all in accordance with } \\
\text { Islamic values and } \\
\text { teachings as well as the } \\
\text { Charter of the United } \\
\text { Nations and the Universal } \\
\text { Declaration on Human } \\
\text { Rights }\end{array}$ & $\begin{array}{l}\text { OIC resolution } \\
\text { does not "reaffirm" } \\
\text { commitment to } \\
\text { UDHR. Rather } \\
\text { only acknowledges } \\
\text { UDHR after } \\
\text { invocation of OIC- } \\
\text { specific documents } \\
\text { including CDHRI } \\
\text { and "Islamic } \\
\text { values and } \\
\text { teachings." }\end{array}$ \\
\hline
\end{tabular}

92 Bangkok Declaration, supra note 86.

${ }^{93}$ OIC Res. 41/21, supra note 90. 


\begin{tabular}{|c|c|c|}
\hline Bangkok Declaration & $\begin{array}{l}\text { OIC Resolution on } \\
\text { HR Coordination }\end{array}$ & Comment \\
\hline $\begin{array}{l}\text { Preamble: Reaffirming } \\
\text { the principles of respect } \\
\text { for national sovereignty, } \\
\text { territorial integrity and } \\
\text { non-interference in the } \\
\text { internal affairs of States }\end{array}$ & $\begin{array}{l}\text { Preamble: } \\
\text { Reaffirming the } \\
\text { principles of respect for } \\
\text { national sovereignty, } \\
\text { territorial integrity and } \\
\text { non-interference in the } \\
\text { internal affairs of states }\end{array}$ & Verbatim. \\
\hline $\begin{array}{l}\text { Preamble: Recognizing } \\
\text { that the promotion of } \\
\text { human rights should be } \\
\text { encouraged by } \\
\text { cooperation and } \\
\text { consensus, and not } \\
\text { through confrontation } \\
\text { and the imposition of } \\
\text { incompatible values }\end{array}$ & $\begin{array}{l}\text { Preamble: } \\
\text { Recognizing that the } \\
\text { promotion and } \\
\text { protection of human } \\
\text { rights should be } \\
\text { encouraged by } \\
\text { cooperation and } \\
\text { consensus, and not } \\
\text { through confrontation } \\
\text { and the imposition of } \\
\text { incompatible values }\end{array}$ & Virtually verbatim. \\
\hline $\begin{array}{l}\text { Preamble: Reiterating } \\
\text { the interdependence and } \\
\text { indivisibility of } \\
\text { economic, social, } \\
\text { cultural, civil and } \\
\text { political rights, and the } \\
\text { inherent } \\
\text { interrelationship } \\
\text { between development, } \\
\text { democracy, universal } \\
\text { enjoyment of all human } \\
\text { rights, and social } \\
\text { justice, which must be } \\
\text { addressed in an } \\
\text { integrated and balanced } \\
\text { manner }\end{array}$ & $\begin{array}{l}\text { Preamble: } \\
\text { Reiterating the } \\
\text { interdependence and } \\
\text { indivisibility of } \\
\text { economic, social, } \\
\text { cultural, civil and } \\
\text { political rights, and the } \\
\text { inherent } \\
\text { interrelationship } \\
\text { between development, } \\
\text { democracy, universal } \\
\text { enjoyment of all human } \\
\text { rights, and social justice } \\
\text { which must be } \\
\text { addressed in an } \\
\text { integrated and balanced } \\
\text { manner }\end{array}$ & Verbatim. \\
\hline
\end{tabular}




\begin{tabular}{|c|c|c|}
\hline Bangkok Declaration & $\begin{array}{l}\text { OIC Resolution on } \\
\text { HR Coordination }\end{array}$ & Comment \\
\hline $\begin{array}{l}\text { 1. Reaffirm their } \\
\text { commitment to the } \\
\text { principles contained in } \\
\text { the Charter of the } \\
\text { United Nations and the } \\
\text { Universal Declaration } \\
\text { on Human Rights as } \\
\text { well as the full } \\
\text { realization of all human } \\
\text { rights throughout the } \\
\text { world; }\end{array}$ & $\begin{array}{l}\text { 1. Reaffirms its } \\
\text { commitment to the } \\
\text { principles contained in } \\
\text { the Charter of the OIC } \\
\text { as well as the "Cairo } \\
\text { Declaration on Human } \\
\text { Rights in Islam" as } \\
\text { general guidelines and } \\
\text { the Charter of the } \\
\text { United Nations. }\end{array}$ & $\begin{array}{l}\text { OIC resolution omits } \\
\text { affirmation of } \\
\text { commitment to } \\
\text { UDHR and to full } \\
\text { realization of human } \\
\text { rights. }\end{array}$ \\
\hline $\begin{array}{l}\text { 5. Emphasize the } \\
\text { principles of respect for } \\
\text { national sovereignty and } \\
\text { territorial integrity as } \\
\text { well as non-interference } \\
\text { in the internal affairs of } \\
\text { States, and the non-use } \\
\text { of human rights as an } \\
\text { instrument of political } \\
\text { pressure; }\end{array}$ & $\begin{array}{l}2 . \text { Emphasizes the } \\
\text { principles of respect for } \\
\text { national sovereignty and } \\
\text { territorial integrity as } \\
\text { well as non-interference } \\
\text { in the internal affairs of } \\
\text { states, and the non-use } \\
\text { of human rights as an } \\
\text { instrument of political } \\
\text { or economic pressure. }\end{array}$ & $\begin{array}{l}\text { Virtually verbatim. } \\
\text { OIC resolution adds } \\
\text { reference to } \\
\text { economic pressure. }\end{array}$ \\
\hline $\begin{array}{l}\text { 6. Reiterate that all } \\
\text { countries, large and } \\
\text { small, have the right to } \\
\text { determine their political } \\
\text { systems, control and } \\
\text { freely utilize their } \\
\text { resources, and freely } \\
\text { pursue their economic, } \\
\text { social and cultural } \\
\text { development; }\end{array}$ & $\begin{array}{l}\text { 3. Reiterates that all } \\
\text { countries, large and } \\
\text { small, have the right to } \\
\text { determine their political } \\
\text { systems, control and } \\
\text { freely utilize their } \\
\text { resources, and freely } \\
\text { pursue their economic, } \\
\text { social and cultural } \\
\text { development. }\end{array}$ & Verbatim. \\
\hline $\begin{array}{l}\text { 7. Stress the } \\
\text { universality, objectivity } \\
\text { and non-selectivity of all } \\
\text { human rights and the } \\
\text { need to avoid the } \\
\text { application of double } \\
\text { standards in the } \\
\text { implementation of } \\
\text { human rights and its } \\
\text { politicization, and that } \\
\text { no violation of human } \\
\text { rights can be justified; }\end{array}$ & $\begin{array}{l}\text { 4. Stresses the necessity } \\
\text { of achieving } \\
\text { universality, objectivity, } \\
\text { and non-selectivity in } \\
\text { the application of } \\
\text { human rights standards } \\
\text { and instruments. }\end{array}$ & $\begin{array}{l}\text { Similar } \\
\text { construction. } \\
\text { However, OIC } \\
\text { resolution omits } \\
\text { recognition that "no } \\
\text { violation of human } \\
\text { rights can be } \\
\text { justified." }\end{array}$ \\
\hline
\end{tabular}




\begin{tabular}{|c|c|c|}
\hline Bangkok Declaration & $\begin{array}{l}\text { OIC Resolution on } \\
\text { HR Coordination }\end{array}$ & Comment \\
\hline $\begin{array}{l}\text { 8. Recognize that while } \\
\text { human rights are } \\
\text { universal in nature, } \\
\text { they must be considered } \\
\text { in the context of a } \\
\text { dynamic and evolving } \\
\text { process of international } \\
\text { norm-setting, bearing in } \\
\text { mind the significance of } \\
\text { national and regional } \\
\text { particularities and } \\
\text { various historical, } \\
\text { cultural and religious } \\
\text { backgrounds; }\end{array}$ & $\begin{array}{l}\text { 5. Recognizes that while } \\
\text { human rights are } \\
\text { universal in nature, } \\
\text { they must be considered } \\
\text { in the context of a } \\
\text { dynamic and evolving } \\
\text { process of international } \\
\text { norm-setting, taking } \\
\text { into account the various } \\
\text { historical, cultural and } \\
\text { religious backgrounds } \\
\text { and the principal legal } \\
\text { systems. }\end{array}$ & $\begin{array}{l}\text { Similar } \\
\text { construction. OIC } \\
\text { resolution front-ends } \\
\text { historical, cultural } \\
\text { and religious } \\
\text { backgrounds and } \\
\text { accounts for } \\
\text { different legal } \\
\text { systems. }\end{array}$ \\
\hline $\begin{array}{l}\text { 11. Emphasize the } \\
\text { importance of } \\
\text { guaranteeing the } \\
\text { human rights and } \\
\text { fundamental freedoms } \\
\text { of vulnerable groups } \\
\text { such as ethnic, national, } \\
\text { racial, religious and } \\
\text { linguistic minorities, } \\
\text { migrant workers, } \\
\text { disabled persons, } \\
\text { indigenous peoples, } \\
\text { refugees and displaced } \\
\text { persons; }\end{array}$ & N/A & $\begin{array}{l}\text { OIC resolution omits } \\
\text { reference } \\
\text { guaranteeing the } \\
\text { human rights and } \\
\text { fundamental } \\
\text { freedoms of } \\
\text { vulnerable groups. }\end{array}$ \\
\hline $\begin{array}{l}\text { 22. Reaffirm their } \\
\text { strong commitment to } \\
\text { the promotion and } \\
\text { protection of the rights } \\
\text { of women through the } \\
\text { guarantee of equal } \\
\text { participation in the } \\
\text { political, social, } \\
\text { economic and cultural } \\
\text { concerns of society; }\end{array}$ & $\begin{array}{l}\text { 15. Reaffirms its strong } \\
\text { commitment, in } \\
\text { accordance with article } 6 \\
\text { of the "Cairo Declaration } \\
\text { on Human Rights in } \\
\text { Islam", to the promotion } \\
\text { and protection of the } \\
\text { rights of women. }\end{array}$ & $\begin{array}{l}\text { OIC resolution } \\
\text { limits guarantee of } \\
\text { equality for women } \\
\text { to "human } \\
\text { dignity." } 94\end{array}$ \\
\hline
\end{tabular}

${ }_{94}$ Under the CDHRI, "(a) Woman is equal to man in human dignity, and has rights to enjoy as well as duties to perform; she has her own civil entity and financial independence, and the right to retain her name and lineage. (b) The husband is responsible for the support and welfare of the family." CDHRI, supra note 16. 


\begin{tabular}{|l|l|l|}
\hline Bangkok Declaration & \multicolumn{1}{|c|}{$\begin{array}{c}\text { OIC Resolution on } \\
\text { HR Coordination }\end{array}$} & \multicolumn{1}{c|}{ Comment } \\
\hline $\begin{array}{l}\text { 24. Welcome the } \\
\text { important role played by } \\
\text { national institutions in } \\
\text { the genuine and }\end{array}$ & N/A & $\begin{array}{l}\text { OIC resolution omits } \\
\text { reference to role for } \\
\text { national human } \\
\text { rights institutions. } \\
\text { of human rights, and } \\
\text { believe that the } \\
\text { conceptualization and } \\
\text { eventual establishment } \\
\text { of such institutions are } \\
\text { best left for the States to } \\
\text { decide; }\end{array}$ \\
\hline
\end{tabular}

The OIC's 1993 human rights coordination resolution additionally posits that the CDHRI's "valuable guidelines" can make a contribution to the World Conference. ${ }^{95}$ The resolution closes by directing the OIC Secretary General "to transmit this resolution along with the 'Cairo Declaration on Human Rights in Islam' to the Secretary General of the World Conference on Human Rights as [the OIC's] contribution ... to the Conference." 96 Considered in its entirety, the OIC's 1993 resolution purports to do more damage to the promise of universal human rights than the Bangkok Declaration. Unsatisfied with merely reiterating problematic sections of the Bangkok Declaration that diminish the principle of universality and advocate non-intervention, the OIC goes further, by omitting or limiting other rights, principles, and institutions recognized elsewhere in the Declaration.

The tensions manifested in the regional declarations discussed above-as well as in the OIC's 1993 resolution on human rights coordination-became fodder for negotiations during the World Conference on Human Rights. ${ }^{97}$ Some elements introduced in the Bangkok Declaration underwent linguistic transformation before making their way into the final outcome document of the World Conference on Human Rights, otherwise known as the Vienna Declaration and Programme of Action ("VDPA"). 98

These changes, however innocuous in appearance, are significant; they shift the priority away from national and regional particularities and back to protecting the universality of human rights. In other words, rather than enable the Bangkok Declaration's national and regional "particularities" to undercut

95 OIC Res. 41/21, supra note 90, pmbl.

${ }^{96}$ Id. $\mid 19$

${ }^{97}$ Boerefijn, supra note 71, 9 5. Boerefijn confirms that "[t]ensions were indeed clearly discernible in Vienna. States questioned the universality of human rights and the legitimacy of addressing the human rights situation against the will of the State concerned." Id.

98 VDPA, supra note 62. 
universal human rights, the VDPA flips the formulation to return primacy to universality, holding states to the unqualified recognition that human rights are universal. While particularities must be "borne in mind," statesirrespective of such peculiarities - share a duty to "promote and protect all human rights and fundamental freedoms." 99 As one commentator has observed, "the Vienna document emphasizes more the universality of human rights, while the Bangkok declaration stresses the necessity to take into account national and regional particularities as well ... [Motivation for the latter formulation flows from] attempts to justify human rights violations caused by political, economic or other interests." 100

Table 2: Comparison of Bangkok Declaration, OIC 1993 Resolution, and Vienna Declaration

\begin{tabular}{|c|c|c|}
\hline $\begin{array}{c}\text { Bangkok } \\
\text { Declaration } \\
(1993) \\
\end{array}$ & $\begin{array}{c}\text { OIC HR } \\
\text { Coordination } \\
\text { Resolution (1993) } \\
\end{array}$ & $\begin{array}{c}\text { Vienna Declaration } \\
\text { \& Program of Action } \\
(1993) \\
\end{array}$ \\
\hline $\begin{array}{l}\text { 8. Recognize that } \\
\text { while human rights } \\
\text { are universal in } \\
\text { nature, they must be } \\
\text { considered in the } \\
\text { context of a dynamic } \\
\text { and evolving process of } \\
\text { international norm- } \\
\text { setting, bearing in } \\
\text { mind the significance } \\
\text { of national and } \\
\text { regional particularities } \\
\text { and various historical, } \\
\text { cultural and religious } \\
\text { backgrounds; }\end{array}$ & $\begin{array}{l}5 . \text { Recognizes that } \\
\text { while human rights are } \\
\text { universal in nature, } \\
\text { they must be } \\
\text { considered in the } \\
\text { context of a dynamic } \\
\text { and evolving process of } \\
\text { international norm- } \\
\text { setting, taking into } \\
\text { account the various } \\
\text { historical, cultural and } \\
\text { religious backgrounds } \\
\text { and the principal legal } \\
\text { systems. }\end{array}$ & $\begin{array}{l}\text { 5. All human rights are } \\
\text { universal, indivisible } \\
\text { and interdependent } \\
\text { and interrelated. The } \\
\text { international } \\
\text { community must treat } \\
\text { human rights globally } \\
\text { in a fair and equal } \\
\text { manner, on the same } \\
\text { footing, and with the } \\
\text { same emphasis. While } \\
\text { the significance of } \\
\text { national and regional } \\
\text { particularities and } \\
\text { various historical, } \\
\text { cultural and religious } \\
\text { backgrounds must be } \\
\text { borne in mind, it is the } \\
\text { duty of States, } \\
\text { regardless of their } \\
\text { political, economic and } \\
\text { cultural systems, to } \\
\text { promote and protect all } \\
\text { human rights and } \\
\text { fundamental freedoms. }\end{array}$ \\
\hline
\end{tabular}

\footnotetext{
99 See Table 2.

100 Rein Müllerson, Human Rights Diplomacy 82 (1997).
} 
Despite the consensus adoption of the VDPA during the 1993 World Conference, the OIC has renewed its endorsement of the Bangkok Declaration's attenuated vision of universality in its annual human rights resolutions since 1993. ${ }^{101}$ This consistent position confirms not only the significant-if subtle-linguistic tweak accomplished under the VDPA, but also the OIC's ongoing malaise with clearly acknowledging the primacy of universality in the context of defining and protecting human rights.

The OIC's human rights-related resolutions in the years following the 1993 World Conference continue to evidence ambivalence vis-à-vis recognition of universality. For example, from 1991-96, the OIC's CDHRI follow up resolutions contained a preambular paragraph referencing "the objectives of the Charter of the OIC and the Universal Declaration of Human Rights . . . ." 102 But explicit acknowledgement of the UDHR is deleted from the resolution's text beginning in 1998 and until 2004, the last year the OIC issued a standalone resolution dedicated to CDHRI follow up. ${ }^{103}$

In addition to eliminating mention of the UDHR, a new preambular provision introduced in 1998 referred to "the universality and comprehensive nature of the Islamic rules on human rights." 104 While this language does invoke the notion of "universality," its application is limited to the Islamic law relating to human rights and does not function to endorse the universality of international human rights law ("IHRL") itself. ${ }^{105}$ Beyond these preambular

\footnotetext{
101 This operative paragraph is introduced in 1993 but removed from subsequent annual OIC human rights cooperation resolutions until 2005. The language restored in the 2005 resolution, although slightly modified, still clings to the Bangkok formulation and fails to mirror the VDPA: "Asserts that human rights are universal in nature and must be considered in the context of dynamic and evolving process of international norm-setting, bearing in mind the significance of national and regional particularities and various historical, cultural and religious backgrounds." OIC Res. 1/32-Leg, ๆ 1 (June 28-30, 2005). This language is maintained verbatim through 2014. OIC Res. 1/41-Leg, I 1 (June 18-19, 2014). In 2015 and 2016, the OIC introduced slightly revised language that continued to break from the VDPA consensus: "Affirms that human rights are of a universal character and must be perceived within the framework of a dynamic non-static process for the evolvement of international standards with due consideration to national and regional specificities and to the diverse historic, cultural, and religious backgrounds." OIC Res. 1/43-Leg, 9 1 (Oct. 18-19, 2016).
}

102 OIC Res. 37/20, supra note 24; OIC Res. 41/21, supra note 90; OIC Res. 39/22 (Dec. 10-12, 1994); OIC Res. 40/23 (Dec. 9-12, 1995); OIC Res. 41/24 (Dec. 9-13, 1996). The OIC does not appear to have convened a CFM in 1992 or 1997.

103 The preamble from 1998 to 2004 only bears in mind the OIC Charter objectives of promoting and encouraging respect for human rights and fundamental freedoms. See OIC Res. 50/25 (Mar. 15-17, 1998). The OIC stopped passing a resolution specific to the CDHRI after 2004. Subsequently, much of the substance contained in the CDHRI-specific resolutions is carried over to the OIC's annual resolution on human rights coordination. See, e.g., OIC Res. 1/32-Leg, supra note 101.

${ }^{104}$ OIC Res. 50/25, supra note 103, ๆ 2. With some slight variances year to year, the final 2004 resolution recalls "the universality and integral nature of Islamic laws on human rights." OIC Res. 2/31-LEG (June 14-16, 2004).

${ }^{105}$ A similar rationale is invoked elsewhere, including during the 1998 UN-OIC seminar on Islam and Universal Human Rights discussed infra Part II(D)(2). According to M. Javad Zarif, "Islam in 
changes, the 1998 CDHRI follow up resolution, for the first time, directed the OIC, "pursuant to the principles enshrined in the Cairo Declaration, to start the formulation and consideration of Islamic covenants on human rights." 106 This operative provision signaled the OIC's willingness to further detach itself from the promise of universality, inasmuch as it enshrined the CDHRI's relativistic vision as a basis for generating binding human rights treaties.

\section{An OIC-Sponsored Seminar on Enriching the Universality of Human Rights Falls Flat}

The OIC's ambivalence towards unqualified endorsement of universality and the UDHR is neatly encapsulated in an underreported 1998 UN seminar entitled "Enriching the Universality of Human Rights: Islamic Perspectives on the Universal Declaration of Human Rights." Iran initiated the seminar "to facilitate a process of preparing Islamic commentaries on the Universal declaration." 107 After some negotiation, it was convened under the auspices of the UN's High Commissioner for Human Rights, Mary Robinson, working closely with the OIC. ${ }^{108}$ The two-day event revolved around three primary themes:

1. Islam, the principle of non-discrimination and the UDHR;

2. Islam, civil and political rights and the UDHR; and

3. Islam, economic, social and cultural rights and the UDHR. ${ }^{109}$

The UN Office of the High Commissioner for Human Rights ("OHCHR") and the OIC selected 20 expert participants based on the "depth of their Islamic legal background and knowledge of human rights law," 110 and tasked them only with providing general "views and opinions on the issue." By design, this narrow remit did not call upon participants to "review current practice

itself was of a universal character, therefore, its prescriptions of human rights were universal, and by that token, human rights were universal." M. Javad Zarif, Islamic Contribution to Enriching the Universal Declaration of Human Rights, paper submitted to United Nations Seminar "Enriching the Universality of Human Rights: Islamic Perspectives on the Universal Declaration of Human Rights," at 155, U.N. Doc. HR/IP/SEM/1999/1 (Mar. 15, 1999).

106 OIC Res. 50/25, supra note 103, 9 . This provision is elaborated in subsequent years, explaining that each covenant "shall deal with one or several issues in detail based on the provisions of the [CDHRI], and . . . be considered in special meetings in preparation for recommending their submission to the Islamic Conference of Foreign Ministers.” See e.g., OIC Res. 55/26, ๆ 2 (June 28July 1, 1999); OIC Res. 2/31-Leg, supra note 104, ๆ 2.

${ }^{107}$ Remarks of Mary Robinson, United Nations Seminar "Enriching the Universality of Human Rights: Islamic Perspectives on the Universal Declaration of Human Rights," U.N. Doc. HR/IP/SEM/1999/1 (Part I) (Mar. 15, 1999).

${ }^{108} \mathrm{Id}$. $\mid$ 8. OIC countries reportedly financed the event at a cost of nearly $\$ 500,000$. David Littman, Islamism Grows Stronger at the United Nations, 6.3 MidDLE EAST Q. (June 1, 1999), http://www.meforum.org/477/islamism-grows-stronger-at-the-united-nations.

109 Robinson, supra note 107.

${ }^{110} I d$. Twenty experts "were selected by the High Commissioner, in consultation with OIC." Id. 
with regard to the protection of human rights" nor enable them "to reach conclusions or adopt positions." 111

Although the original plan for the seminar initially envisioned a small, closed meeting, this was later revised to enable "observers" from governments, NGOs and the public. Despite this opening, in High Commissioner Robinson's words, "to preserve the basic scholarly objective, the discussion itself [would] be limited to the invited experts." 112 Thus, the seminar's design also formally prohibited the audience from asking questions. This curious restriction prompted at least one observer to note that, "[f]or the first time at a U.N. public seminar, no questions were allowed from the more than 250 participants from about 80 states, intergovernmental, and U.N. bodies, as well as 41 NGOs." 113

In her opening remarks to the seminar, High Commissioner Robinson took pains to express her particular hope that the "discussions will deepen our understanding" of UDHR Art. 29(1), providing that "[e]veryone has duties to the community in which alone the free and full development of his personality is possible." 114 Robinson's peculiar emphasis on individual duties to the community during a seminar intended to examine Islamic perspectives on the UDHR represented a frontal betrayal of the Declaration's rights-driven purpose. It also appeared at odds with the seminar's stated themes. Every "operative" article in the UDHR promulgates an individual right or government prohibition, with article 29 being the lone exception. In fact, the term "duties" appears but once in the entire Declaration. Directing the seminar's attention away from rights and towards this isolated provision essentially created a justificatory framework for abandoning a focus on rights and universalism. Instead, the framing invited deliberations emphasizing the individual's obligations to the state. Not coincidentally, this emphasis fit squarely into the OIC's relativistic modus vivendi of placing the state's religious values ahead of individual rights. As Theo van Boven has aptly explained elsewhere in regard to the drafting of UDHR article 29:

The issue of duties was duly and thoroughly discussed. But the view that prevailed was that, while a balance between rights and duties must be attained, the need to guarantee rights as an international undertaking was more pressing than the need for a catalogue of duties. In the relationship between the individual and the state the balance of power usually tilts overwhelmingly to the side of the state and international

\footnotetext{
111 Robinson, supra note 107, ๆ 10.

${ }^{112} I d$. ๆ 12 .

${ }_{113}$ David G. Littman, Human Rights and Human Wrongs, NAT'L REv. (Jan. 19, 2003, 7:00 PM), http://www.nationalreview.com/article/205577/human-rights-and-human-wrongs-david-glittman. Littman, supra note 108 ("Observers agreed that this format was unprecedented within the United Nations system; certainly, it was much deplored, even by some diplomats from OIC member states.").

${ }^{114}$ Robinson, supra note 107, ๆ 13 (internal quotations omitted).
} 
human rights guarantees are designed precisely to protect the individual against the abuse of power and to help ensure a life of dignity for all. 115

OIC Secretary General Azeddine Laraki's opening remarks to the seminar added another proverbial finger on the scale. Laraki failed to expressly endorse the UDHR, and instead asserted that the seminar would afford an "elite of Muslim experts in the field of Sharia and Law"116 the opportunity to present research "expound[ing] the Islamic perspective as to human rights . . . on the basis of the ... sources of Islamic Sharia." 117 Further on, plainly alluding to limitations on rights, Laraki stressed the seminar's role in "highlighting the message of Islam in terms of human rights and in underscoring the importance of cultural and religious specificities."118

During the two-day seminar, participants posited laudable general statements to the effect that "sharia was not contrary to the provisions of the Universal Declaration," 119 and "[e]fforts should be made to put an end to the myth of the incompatibility of Islamic teachings with the [UDHR]." 120 Nevertheless, even the seminar's summary record managed to capture the clearly discernable fault lines. During the first session, Dr. Ahmad Kamal Aboulmagd, an Egyptian constitutional and Islamic law expert, took a cue from High Commissioner Robinson and declared the "need for a universal declaration of human responsibilities." 121 The pronouncement likely alluded to

115 Theo van Boven, A Universal Declaration of Human Responsibilities?, in REFLECTIONS ON THE UNIVERSAl DECLARATION OF HUMAN RightS: A FIFTIETH ANNIVERSARY ANTHOLOGY 75 (Barend van der Heijan \& Bahia Tahzib Lie eds., 1998).

116 The omission of human rights experts here is noteworthy.

117 Remarks of Azeddine Laraki, United Nations Seminar "Enriching the Universality of Human Rights: Islamic Perspectives on the Universal Declaration of Human Rights, 6, U.N. Doc. HR/IP/SEM/1999/1(Part I) (Mar. 15, 1999).

${ }_{118} I d$.

119 Summary Record of the $3 d$ Meeting, Seminar on Enriching the Universality of Human Rights: Islamic Perspectives on the Universal Declaration of Human Rights, 45, U.N. Doc. HR/IP/SEM/1998/TR.3 (Nov. 10, 1998) [hereinafter Summary Record of the 3d Meeting].

${ }_{120}$ Summary Record of the 2d Meeting, Seminar on Enriching the Universality of Human Rights: Islamic Perspectives on the Universal Declaration of Human Rights, 26, U.N. Doc. HR/IP/SEM/1998/TR.2, (Nov. 9, 1998) [hereinafter Summary Record of the 2d Meeting].

${ }^{121}$ Summary Record of the 1st Meeting, Seminar on Enriching the Universality of Human Rights: Islamic Perspectives on the Universal Declaration of Human Rights, 12, U.N. Doc. HR/IP/SEM/1998/TR.1, (Nov. 9, 1998) [hereinafter Summary Record of the 1st Meeting]. 
a problematic document ${ }^{122}$ previously proposed by the InterAction Council ${ }^{123}$ and "hailed as a victory" by supporters of the campaign to amend the UDHR's alleged western bias. ${ }^{124}$ Aboulmagd then proceeded to deride the writings of certain prominent human rights scholars, "even including Moslem writers such as Abdullah Al-Naeem [Na'im] or Hassam Taibi [Tibi]," because-though they advocated in favor of Islam's compatibility with universal human rights"they were futile and useless aberrations because they lacked the basic element of cultural legitimacy." ${ }^{125}$ Later on, Mr. Sahib Ben Cheikh, an Algerian mufti, went so far as to rewrite history by claiming "that Moslems were virtually absent from the international scene at the time when the Universal Declaration of Human Rights was elaborated."126

122 Despite its high-profile membership, the InterAction Council's proposal was not without criticism. Drawing on the analogy that human rights norms should be protected in a manner similar to appellation for wine, Fried van Hoof offered the devastating conclusion that the proposed Universal Declaration of Human Responsibilities "tastes like [nothing] other than vinegar." Fried van Hoof, A Universal Declaration of Human Responsibilities: Far-Sighted or Flawed?, in To

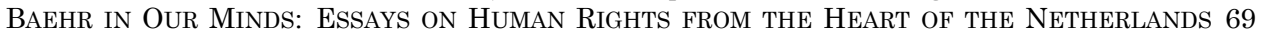
(Mielle Bulterman et al. eds., 1998). Among van Hoof's primary concerns, the Declaration purported to achieve balance between freedom and responsibility, despite an existing structure that already accounted for various competing interests, including rights and responsibilities. Id. More directly, by omitting mention of certain existing rights and diluting the substance of others, the Declaration's content neglected the original impetus for promoting and protecting human rights, namely protecting individuals from "anti-democratic ideologies and its accomplices." Id. at 65-67. In a letter to the UN secretary general Kofi Annan, nine global press freedom organizations labeled InterAction's declaration "a serious new threat to press freedom" that "undercut[s] existing human rights," and "the strength and universality" of the UDHR. Letter from the World Press Freedom Committee, in A GLOBAL ETHIC AND GLOBAL RESPONSIBILITIES: Two DECLARATIONS 13435 (Hans Kung \& Helmut Schmidt eds., 1998). The letter concluded by urging the Secretary General to reaffirm the UDHR's universality "and to seek its full implementation," rather than to endorse efforts to "amend or rewrite it so that authoritarians may negate the fundamental freedoms it provides." Id.

${ }^{123}$ A Universal Declaration of Human Responsibilities, INTERACTION COUNCIL (Sept. 1, 1997), https://www.interactioncouncil.org/index.php/publications/universal-declaration-human-

responsibilities. For a detailed account of the drafting of the declaration, see Johannes Frühbauer, From the Declaration of the Religions to the Declaration of the Statesmen: Stages in the Composition of the Declaration on Human Responsibilities, in A Global ETHIC AND GLOBAL Responsibilities: Two DeClaRATIONS 84-103, (Hans Kung \& Helmut Schmidt eds., 1998).

${ }^{124}$ Hoof, supra note 122, at 62-63 (noting support for the Universal Declaration of Human Responsibilities from Mahathir Mohamad, Malaysia's then-and now current-prime minister).

${ }_{125}$ Summary Record of the 1st Meeting, supra note 121, at 12.

${ }^{126}$ Summary Record of the 2d Meeting, supra note 120, at 26. Susan Waltz disproves Ben Cheikh's proposition: "It is often supposed that international human rights standards were negotiated without active participation by Middle Eastern and Muslim states. That was not the case." Susan Waltz, Universal Human Rights: The Contribution of Muslim States, 26 HuM. RTS. Q. 799, 799 (2004). Waltz acknowledges that "many Middle Eastern states were not yet members of the UN" during drafting of the UDHR. However, "Lebanon and Egypt were represented on the Commission [responsible for drafting the UDHR] during the first years of the UN, and they made direct contributions to early drafts" of the Declaration. Furthermore, after the UN Third Committee received the draft Declaration in 1948, various Muslim-majority states registered interventions, including Afghanistan, Egypt, Iraq, Lebanon, Pakistan, Saudi Arabia, and Syria. Id. at 807. The UNDP's 2004 Arab Human Development Report similarly repudiates Ben Cheikh's assertion, observing that such a view "underestimates the extent of the Arab contribution, whether on the 
Despite the general assurances of compatibility between sharia and the UDHR, other remarks on specific topics signaled the existence of sharia-based redlines that deviated from universality. For example, Dr. Hossein Mehrpour, an advisor to Iran's president, conceded that while the UDHR guarantees every individual freedoms of opinion, religion and belief, under Islam "defence or promotion of polytheism and of the right to deny God was not permissible." 127 Similarly, while Lebanese scholar Dr. Ridwan El-Sayyid observed "there was no conflict on equality in human value," he reminded participants that "debate continued on the equality between citizens including the followers of other religions or cultures." 128 Likewise, the issue of securing women's equality "was the most difficult because many of its elements ... were directly and fundamentally embedded in religious texts which Moslems considered beyond any questioning." 129

In contrast with these observations, other experts held out the possibility of achieving compatibility with universality by developing new consensusbased interpretations of sharia. For example, Ms. Mashuda Shefali, Director of the Bangladesh-based Center for Women's Initiatives, identified "the rise of religious fundamentalism and the politicization of Islam [as responsible for] restricting women's mobility and their access to basics such as food, employment, shelter and education." 130 According to her, those fighting for women's rights "on the grounds that they were basic, inalienable human rights" exposed themselves to "further marginalization by male-dominated organizations and authorities: they were accused of being 'westernized' or 'opponents' of Islam, two charges with great resonance in popular Islamic tradition and culture." 131

Similarly, Professor Norani Othman, a representative of Malaysia-based Sisters in Islam, ${ }^{132}$ noted the larger "problem faced by contemporary Moslems was . . 'the problem of interpretation' of the foundational texts of Islam." 133 Othman reasoned that without a clear consensus over interpretation, selective verses of the Koran might be misused to justify exclusivity or inequality: "The

part of the Arab states that actively and effectively participated in debates on the substantive elements of human rights standards, or in the persons of distinguished Arab experts who helped shape international human rights law.” ARAB HUMAN DEVELOPMENT REPORT 2004: TOWARDS FREEDOM IN THE ARAB WORLD 75 (2004).

${ }^{127}$ Summary Record of the 2d Meeting, supra note 120, at 29-31.

${ }^{128}$ Summary Record of the 3d Meeting, supra note 119, at 44.

${ }^{129} I d$.

${ }^{130} I d$. at 40 .

${ }^{131} I d$. at 41 .

132 Mission Statement and Objectives, SISTERS IN ISLAM, http://sistersinislam.org.my/page.php?36 (last visited Nov. 21, 2018).

${ }^{133}$ Summary Record of the 4th Meeting, Seminar on Enriching the Universality of Human Rights: Islamic Perspectives on the Universal Declaration of Human Rights, 49, U.N. Doc. HR/IP/SEM/1998/TR.4 (Nov. 9-10, 1998). 
problem of exclusivity gave rise to the question of the rights which the followers of one religion might obtain but from which the followers of another religion might be excluded." 134 Elsewhere, Othman asserted scholars should "not fudge around [the] realistic and actual problems in modern times" that impact diverse issues such as "the right to work or the right to education . . . . gender relations or reproductive rights . . . guardianship and custody of children." 135

These latter views-notably of two female experts in attendanceaccentuate the challenge identified previously. Namely, while claims of compatibility between sharia and universal human rights may suffice on a general level, any meaningful engagement on the "plane of actual implementation" necessitates more detailed exposition of sharia-based norms. Such an exposition, in the view of these experts, may require the "adjusting and adapting [of sharia sources] to the contemporary needs," so as to bridge "the gaps between classical juristic thinking and modern demands in respect of questions of human rights ...."136 But the effort to delve into the challenge of actual implementation at the UN seminar quickly hit a wall. At least two other experts cautioned that "the Seminar was not the right forum to raise controversial matters ... because the discussion of such matters required more time, more specific specializations and more representatives of various jurisprudential schools . . .."137

In closing the seminar, High Commissioner Robinson was laudatory: "no one expressed doubts about the [UDHR] nor denied the legitimacy or universality of international human rights standards. And we have heard of the relevance of international standards, including the Universal Declaration, to promoting and protecting human rights on the national level." 138 Robinson's readout of the event, however, was an overly sanguine one. More accurately, certain experts cautiously posited that sharia had the capacity for consistency with the UDHR. But still others accepted and endorsed redlines beyond which sharia could not move. These experts further urged avoiding any type of engagement to grapple with the implementation problems generated by certain interpretations of sharia. For example, some experts highlighted the need to separate religious requirements from practices that were "conditioned

\footnotetext{
${ }^{134} I d$.

135 Summary Record of the 1st Meeting, supra note 121, at 21.

${ }^{136} I d$.

${ }^{137}$ Summary Record of the 3d Meeting, supra note 119, at 36.

${ }^{138}$ Remarks of Mary Robinson, Personal Impressions of the Seminar on Enriching the Universality of Human Rights: Islamic Perspectives on the Universal Declaration of Human Rights, 162, U.N. Doc. HR/IP/SEM/1959 (Nov. 8-9, 1998). During her closing remarks, Robinson expressed her pleasure at the high number of OIC states that had ratified the UN Convention on the Rights of the Child (UNCRC). Id. The OIC would go on to release its own Covenant on the Rights of the Child in Islam (CRCI) six years later, a treaty that boasts provisions antithetical to the very UNCRC norms intended to protect the rights of children. Blitt, supra note 1, at 772-74.
} 
by cultural and social backgrounds." 139 Similarly, they reasoned that Muslims need to be able to identify "those ideas [that] came from interpretations by classical juristic thinkers who were conditioned by the historical socioeconomic and cultural conditions of their time." ${ }^{140}$ Dr. Mustafa Ceric, the Grand Mufti of Bosnia, offered an unvarnished conclusion on this view: "Islam was not guilty, but it was the attitudes of Moslems that were the cause for their suffering under illiteracy, poverty, difficult democratic processes and complaints by women." 141

OIC Secretary General Azeddine Laraki's concluding remarks further testify to the High Commissioner's simplistic assessment. Speaking on behalf of OIC member states, Laraki bluntly rejected a seminar participant's proposal for a follow up "meeting of a group of Moslem scholars, outside of any official umbrella to handle matters that related to Islam and human rights . . . . Perhaps ... [to] be followed by a meeting with scholars from the West." 142 In doing so, Laraki also dismissed the apparently loaded premise voiced by the proposal's sponsor: "of course there would be some differences but that was acceptable ... [because] there was [still] so much in common." 143

Judging from this tense wrap up, it would appear the OIC remained unready to embrace the implications that might flow from the universality of human rights. More than this, the seminar proceedings themselves betrayed an ongoing effort by the OIC to tightly control the nature of the dialogue surrounding Islam and human rights. Indeed, a willingness to quash discussion of "controversial" matters, ad hominem attacks blasting internationally recognized scholars of Islam and human rights as "useless aberrations," and the glaring shut down of the mere suggestion of engagement on Islam outside of official OIC control (or with western scholars!) all signal that the OIC operates as the "collective voice of the Muslim world" only to a point.

As one scholar has observed, "warts and all, from its glorious nobility to misogyny, there has always been a spectrum of interpretations in Islam." 144 Yet despite this history, the OIC has sought to impose artificial constraints on

\footnotetext{
139 Summary Record of the 1st Meeting, supra note 121, at 16.

${ }^{140} \mathrm{Id}$. at 21. A similar position is reiterated by Mr. Ben Cheikh, who claimed "it was the ArabBerberia-Turkish-Persian-Indian culture, and not Islam, that was the source of such inconsistency." Summary Record of the 2d Meeting, supra note 120, at 26-27.

${ }^{141}$ Laraki, supra note 117 at 52.

${ }^{142} I d$.

${ }^{143} I d$.

${ }^{144}$ Omid Safi, Introduction: The Times They are A-Changin'-A Muslim Quest for Justice, Gender Equality, and Pluralism, in Progressive Muslims: On Justice, Gender AND PluRalism, 1, 6 (Omid Safi ed., 2003). Others have made the same observation. See Kecia Ali, Progressive Muslims and Islamic Jurisprudence, in Progressive Muslims: On Justice, Gender AND Pluralism, 163, 167 (Omid Safi ed., 2003) ("there is not now, nor has there ever been, a single, unitary Islamic law.").
} 
this spectrum. To better delineate the OIC's redlines, consider Dr. An-Na'im's "useless" but somehow still menacing proposal:

$[\mathrm{H}]$ uman rights advocates in the Muslim world . . . . need not be confined, however, to the particular historical interpretations of Islam known as Shari'a .... Religious texts, like all other texts, are open to a variety of interpretations. Human rights advocates in the Muslim world should struggle to have their interpretations of the relevant texts adopted as the new Islamic scriptural imperatives for the contemporary world. ${ }^{145}$

An-Na'im's so-called "futile" voice further reasons that "Authority for this reinterpretive activity comes from the fact that contemporary majority perspectives on Shari'a are not necessarily the only valid interpretations of the scriptural imperatives of Islam, a fact which has been recognized by some modernist Muslim reformers." 146 Scholar Ebrahim Moosa has put this challenge more bluntly: "The success of a modem Islamic human rights theory depends on the extent to which modem Islamic thought would be open to a revisionist or reconstructionist approach in philosophy and ethical orientation." ${ }^{147}$ Producing "a credible version of human rights ... dialogue with both the tradition and the present" demands Muslim jurists and scholars "acknowledge that quantum shifts have occurred" in a range of categories, including human society and "inherited conceptions of 'self' and 'other." 148 In Moosa's words, facilitating this dialogue will require nothing less than "a fundamental rethinking." 149

The contemporary difficulty inherent in maintaining and disseminating a more fully representative spectrum of interpretation should not be understated. According to Khaled Abou El-Fadl, another leading authority on Islamic law and human rights:

When it comes to the issue of self-critical appraisals, Muslim discourses, for the most part .... are politicized and polarized to the extent that a Muslim intellectual who takes a critical approach to the Islamic tradition often feels that he is stepping into a minefield. It is difficult for a contemporary Muslim scholar to take a critical position on such matters as Islam and ... women without becoming the subject of

\footnotetext{
${ }^{145}$ Abdullahi Ahmed An-Na'im, Human Rights in the Muslim World: Socio-Political Conditions and Scriptural Imperatives-A Preliminary Inquiry, 3 HARV. HUM. RTS. J. 13, 15 (1990).

${ }^{146} I d$. at 51 (citation omitted).

147 Ebrahim Moosa, The Dilemma of Islamic Rights Schemes, 15 J.L. \& RELIGION 185, 187 (2000) (citation omitted).

148 Id. at 215

${ }^{149} I d$.
} 
suspicion, and even accusations as to his or her loyalties ... .150

Abdulaziz Sachedina is far more blunt. In his assessment, Muslim intellectuals espousing alternate or competing interpretations of Islamic sources put their own lives on the line:

The intolerance exhibited by the religious establishment in some Muslim countries and more recently in Muslim communities in Europe and North America, which feels threatened by the rational assessment of religious texts in their historical context in the universities, has forced these scholars to abandon their religious and moral responsibility to their own community .... For Muslims in general, and their communities in the West in particular, academic study of Islam is a new phenomenon that causes their deep felt insecurities in faith to react strongly against anything that appears to challenge their long-held belief system. ${ }^{151}$

As demonstrated below, the OIC continues to tamp down and deny these reformist voices by wielding a formidable influence over the definition of an Islamic approach to human rights norms. However, its efforts to ostracize AnNa'im, El-Fadl, and other like-minded scholars ${ }^{152}$ has not succeeded in silencing them. ${ }^{153}$

\section{The OIC and Universality in the 21st Century}

The OIC's official position on universality has remained ambivalent in the years following the UN-OIC seminar. The organization's milestone Ten Year Program of Action, discussed above, made no reference to the centrality of universality despite calling for the establishment of an OIC human rights commission. Instead, the document urged expediting development of "The Covenant on the Rights of Women in Islam" based on content in the CDHRI. ${ }^{154}$

The OIC's annual internal resolutions during this period also confirm an ongoing aversion to universalism. For example, in 2005, the OIC consolidated its human rights-related positions into a single resolution, dropping the

\footnotetext{
${ }^{150}$ Khaled Abou El-Fadl, The Ugly Modern and the Modern Ugly: Reclaiming the Beautiful in Islam, in Progressive Muslims: On Justice, Gender AND PluRAlisM, supra note 144, at 40.

${ }^{151}$ Abdulaziz Sachedina, Guidance or Governance? A Muslim Conception of "Two-Cities," 68 GEO. WASH. L. REV. 1079, 1082 n.4 (2000).

152 See id. at 1080 ("The fundamental problem, as reflected in the classical formulation of Muslim political identity, is religious authoritarianism founded upon an exclusive salvific claim, which runs contrary to the emerging global spirit of democratization through acknowledgment of religious pluralism.").

${ }^{153}$ It remains fair to ask whether these scholars have, in fact, succeeded in gaining traction over the OIC's narrative. Id.

${ }^{154}$ OIC Ten Year Program, supra note 41, art. 2(VI)(3).
} 
longstanding separate text focusing on CDHRI follow up. This unified resolution integrated much of the content found in prior CDHRI resolutions. At the same time, it further undercut recognition of universalism in several notable ways. First, it endorsed the freshly drafted Covenant on the Rights of the Child in Islam ("CRCI"), ${ }^{155}$ an OIC treaty that, among other problems, departs from universal human rights by situating sharia and domestic law above any international norms. ${ }^{156}$ Second, like the Ten Year Program of Action, the OIC's new unified resolution called for expediting additional "[c]ovenants on human rights in Islam, in accordance with . . . the principles enshrined in the Cairo Declaration . . .."157 Finally, the resolution also resuscitated an operative paragraph issued only once before, during the lead up to the 1993 World Conference. This paragraph, based on the Bangkok Declaration, formally renewed the OIC's rejection of the consensus language contained in the Vienna Declaration. It "[a]ssert[ed] that human rights are universal in nature and must be considered in the context of dynamic and evolving process of international norm-setting, bearing in mind the significance of national and regional particularities and various historical, cultural and religious backgrounds." 158 The OIC has maintained this formulation-alongside an additional operative paragraph "[r] eaffirm[ing] the right of [S] tates to adhere to their religious, social, and cultural specificities" ${ }^{159}$ - in its resolutions through 2016. ${ }^{160}$

New human rights content introduced in the OIC's 2008 Charter and the creation of the Independent Permanent Human Rights Commission ("IPHRC") may point to more substantial efforts intended to better position the organization to weigh in on international human rights. But adopting such measures also necessitated further clarification of the organization's position on universality. The OIC secretary general's advocacy in favor of setting up the IPHRC exemplifies this overriding tension. In his words, establishing the IPHRC would:

earn the OIC increased credibility and uplift its position in the eyes of the outside world .... [I]t would also give the Organization greater confidence and support in grappling with

\footnotetext{
155 OIC Res. 1/32-Leg, supra note 101, ๆ $14-15$.

156 Blitt, supra note 1, at 772-74.

${ }^{157}$ OIC Res. 1/32-Leg, supra note 101, ๆ 16.

${ }_{158} I d .91$.

${ }^{159} \mathrm{Id}$. ๆ 3. This provision is retained with slight variation through 2016. See OIC Res. 1/43-LEG, supra note 101, ๆ 4 ("Reaffirm[ing] the right for states to uphold their religious, social and cultural specificities which represent legacies and intellectual underpinnings that in turn contribute to enriching common world concepts of human rights.").

160 See OIC Res. 1/41-LEG, supra note 101, ๆ 1. Resolutions from 2015 and 2016 introduced a slight revision: "Affirms that human rights are of a universal character and must be perceived within the framework of a dynamic non-static process for the evolvement of international standards with due consideration to national and regional specificities and to the diverse historic, cultural, and religious backgrounds.” OIC Res. No. 1/43-LEG, supra note 101, \ 1.
} 
the considerable challenges confronting the Islamic world in this area, and provide it with a structure that would help strongly refute outside accusations, and defend the Member States' positions in this field. ${ }^{161}$

Keeping this political calculation in mind, the 2008 Charter attempts to manifest the OIC's commitment to "promote human rights and fundamental freedoms." But at the same time, it leaves this promise disconnected from international norms. ${ }^{162}$ Similarly, the new Charter anticipates the IPHRC shall promote rights enshrined in the OIC's own covenants and declarations, as well as "in universally agreed human rights instruments . . .." 163 But this commitment holds only to the extent such rights are "in conformity with Islamic values." 164 The IPHRC's 2011 statute reiterates this vague formulation, thus perpetuating the OIC's inability to endorse or adhere to an unqualified understanding of universal human rights norms. ${ }^{165}$

With the OIC's 2025 Program of Action, issued in 2015, the organization offered perhaps its clearest, if still qualified, endorsement of universality. According to the document, "there is a strong need for . . renewing the commitment to promoting and protecting all universally accepted human rights"; and "[i]t is important that the observance of all human universal rights and freedoms flow together with Islamic values . . . "166 To this end, the OIC's 2025 action plan establishes two related goals:

2.15.1: Enhance OIC's engagement on promotion and protection of universal human rights as well as effectively portraying the OIC's vision of moderation, tolerance, and protection of the rights guaranteed in the Islamic faith, harmony and modernization, in cooperation and dialogue with Member States.

2.15.4: Update and refine, in consultation with OIC Member States, the existing OIC human rights instruments vis-à-vis universal human rights instruments, as and where required. ${ }^{167}$

\footnotetext{
161 OIC, Report of the Intergovernmental Experts Group Meeting on the Establishment of the OIC Independent Permanent Human Right Commission, ๆ 5, OIC Doc. OIC/EGGHRC2/2010/REP.FINAL (Feb. 15-17, 2010) (emphasis added).

1622008 OIC Charter, supra note 46, pmbl.

${ }^{163} I d$. art. 15.

${ }^{164} I d$.

165 IPHRC Statute, supra note 42, pmbl. While the IPHRC envelops itself with the superficial trappings of an independent supervisory human rights body, among other obvious problems, its formal mandate demands "support[ing] the OIC's position on human rights at the international level . ..." Id. art. 13. For a more detailed critique of the IPHRC, see Blitt, supra note 1, 777-92.

166 OIC, 2025 Programme of Action, ๆ 49, OIC Doc. OIC/SUM-13/2016/POA-Final.

${ }^{167}$ Id. 2.15.1, 2.15.4.
} 
The 2025 Program of Action arguably hints at the alluring possibility of the OIC finally recognizing and seeking to remedy gaps between its approach to human rights and the promise of universality. However, other contemporaneous indicators conveyed by the organization suggest that such an effort is unlikely to be as far-reaching as necessary to ensure that existing equality and non-discrimination norms and other related rights are fully implemented. Former OIC Secretary General Madani has summarized the organization's dilemma candidly: "there are a number of issues that go beyond the normal scope of human rights and clash with Islamic teachings." 168 From this, Madani confirms fundamental discrepancies persist between universal human rights vested on the international level and what the OIC's framing of sharia is prepared to embrace.

The issues flagged by the Secretary General as clashing with shariafreedom of expression, gender equality, and domestic application and enforcement of human rights norms-are not peripheral or trivial in nature. Rather, they engage a cross-section of fundamental human rights that are interconnected and critical to the exercise of other key rights. ${ }^{169}$ In Madani's words, "[o]ne of the main issues relating to [the] gender equality debate is the very definition of [the] term gender. While OIC countries prefer to use the notion of equality between men and women, Western countries push for the term Gender, which goes beyond the normal definition of men and woman into the direction of how one perceives him/herself rather than his/her actual physical appearance." 170

Taking a cue from this perspective, any purported OIC allowance for universality-including equality and nondiscrimination principles-is necessarily constricted in the context of these contested areas. Stated differently, where the OIC's particular (indeterminate) understanding of Islamic norms fails to endorse or tolerate a claimed right, the only permissible explanation for the OIC is that the claimed right falls outside what Madani labels the "normal scope" of universal human rights. The possibility that the organization's understanding of Islamic law is outmoded, a misinterpretation, or otherwise at odds with universal norms is simply not an option. To say that such an approach unduly restricts the promise of universal human rights to the OIC's vision of sharia-permissible rights would be to state the obvious. Plainly, such an approach front-ends the protection of religious belief at the expense of individual rights. But, more than this, by purporting to situate "abnormal" rights beyond the pale, the OIC's approach effectively removes the

\footnotetext{
${ }^{168}$ Statement of Iyad Ameen Madani, supra note 40.

${ }^{169}$ Id. Puzzlingly, the Secretary General omits reference to the right to freedom of thought, conscience and religion or belief as an area where the OIC arguably diverges from the "normal scope" of IHRL. Id.; see Blitt, supra note 64 ("A closer look at the OIC's advocacy favoring a ban on defamation of religion reveals an approach that embodies not one but several anti-constitutional ideas that operate to foreclose the principles of nondiscrimination and equality and undercut universal rights to freedom of expression and freedom of religion or belief.").
}

${ }^{170}$ Statement of Iyad Ameen Madani, supra note 40. 
obligation on governments to justify policies and practices that violate or otherwise limit rights. In essence, these "abnormal" rights are not universal and therefore do not trigger any state obligation that would purport to limit what governments might do.

Ultimately, as the following section confirms, the OIC's contemporary effort to narrowly confine universality operates accordingly: if the right in question is authorized under the OIC's view of sharia, then it can be acknowledged as a universally recognized human right. On the other hand, in the event a given right contradicts the OIC's understanding of sharia, the organization proffers an elaborate multi-stage position to justify denying any obligation to respect that right. In the first instance, such a right is not truly universal and therefore need not be respected; in Madani's words, it is "beyond the normal scope." Second, where the balance of evidence nevertheless favors identifying the right as universally-recognized, the OIC falls back on its relativistic argument that "religious, social, and cultural idiosyncrasies" 171 take precedence over universal rights. ${ }^{172}$ To further bulwark this latter position, the OIC routinely asserts that states must refrain "from using the universality of human rights as a pretext to interfere in the states' internal affairs . . .."173

\section{THE OIC'S CONTEMPORARY ENGAGEMENT WITH EQUALITY AND NON- DISCRIMINATION: DENIAL OF PROTECTION ON BASIS OF SOGI}

To further understand the deleterious impact of the OIC's approach to universality, it is useful to consider how the organization engages the international human rights framework in actual practice, particularly in the context of foundational norms such as equality and nondiscrimination. The previous article in this series demonstrated that the OIC's longstanding defense of different roles and responsibilities for men and women in the context of "gender equality" undercuts women's rights across a range of issues from personal status to sexual and reproductive health. ${ }^{174}$ As that article concluded, the OIC's justification for this break with universal human rights norms

171 OIC Res. 1/41-LEG, supra note 101, ๆ 4.

172 See El-Fadl supra note 150, at 40.

[I] thas become a rather powerful rhetorical device to contend that the West is perpetuating false universalisms...because the user of such a device is positioning himself . . . as the guardian of integrity and authenticity, while positioning his ... opponents as gullible and even simple-minded. In addition, as an extension of the relativism argument, it is often argued that it is immaterial whether the West . . . is offended or shocked by the legal and social practices of Muslims. Islam, it is argued, has its own set of standards for justice and righteousness, and it is of no consequence if those standards happen to be inconsistent with the moral sensitivities of non-Muslims.

${ }^{173}$ See OIC Res. 1/41-LEG, supra note 101, ๆ 5; OIC Res. 1/40-LEG, ๆ 5 (Dec. 9-11, 2013).

${ }^{174}$ Blitt, supra note 1. 
ultimately rest on the organization's particular-though never fully elaborated—understanding of Islamic religious imperatives. ${ }^{175}$

This section expands and confirms the previous article's conclusion by examining the OIC's approach to sexual orientation and gender identity. Although express international recognition of SOGI rights is a relatively new phenomenon, the OIC has responded with strident opposition in the form of organizational resolutions, block voting at the UN, and other efforts elsewhere aimed at rejecting even the application of equality and nondiscrimination principles. Notably, the foundation for this rejection relies on the same relativistic rationale proffered in the context of women's equality. ${ }^{176}$

To demonstrate this, the following section will begin by exploring the OIC's recent advocacy efforts around "protection of the family." This OIC campaign is particularly instructive because it is premised on a religiously-justified insular vision of family that condones inequality and discrimination against women as well as on the basis of SOGI. In this way, OIC efforts to protect what it calls "Islamic family values" serve as a nexus for discrimination against various classes. But similar to the denial of women's equality, the OIC has not relied solely on protection of the family to justify its opposition to extending equality and nondiscrimination protections on the basis of SOGI. Therefore, the section will also examine the OIC's response to SOGI rights arising outside of the family context. Among other things, this additional analysis will demonstrate that OIC opposition to recognition of SOGI rights predates its active engagement on protection of the family. Further, it will show OIC opposition is sourced in alternate justifications that either advocate a narrow reading of universality to preclude protection for SOGI or distort the VDPA to create an exemption from international norms on the basis of religious specificities.

\section{A. Protection of the Family: Nexus for Perpetuating Discrimination Against Women and on the Basis of Sexual Orientation and Gender Identity}

The OIC's blossoming concern for preserving its vision of "Islamic family values" 177 is colored by the same religious imperatives that inform the organization's longstanding defense of different roles and responsibilities for

${ }^{175} I d$.

${ }^{176}$ For example, the OIC's 2008 Plan of Action for the Advancement of Women (“OPAAW"):

premises women's rights on a grant from Islam, qualifies any state party adherence to CEDAW provisions 'in line with Islamic values of justice and equality,' and reiterates support for drafting the [OIC Convention on the Rights of Women in Islam] 'in accordance with . . . the Cairo Declaration on Human Rights in Islam.

Id. at 796 (internal citations omitted) (omission in original).

1772008 OIC Charter, supra note 46, art. 1, If 14; see also 2025 Programme of Action, supra note 166, ๆ 48. 
men and women. ${ }^{178}$ But the push to protect Islamic family values implicates far more than women's equality and nondiscrimination alone. If left unchallenged, the OIC's efforts in this realm would justify a surge of discriminatory practices that would leave the rights of children, refugees, ${ }^{179}$ and LGBTI individuals at equal or greater risk. As it stands, because of its campaign to combat perceived "ethical and intellectual challenges threatening [the Islamic family's] identity and existence," 180 the OIC has emerged as one of the staunchest opponents of extending equality and nondiscrimination protections to SOGI. Notably, this effort to defend a specific vision of "family" against encroaching individual human rights norms stands in stark contradiction to international norms. The OHCHR has expressly recognized that "States' responsibility to protect individuals from discrimination extends to the family sphere, where rejection and discriminatory treatment of and violence against LGBT and intersex family members [including children] can have serious, negative consequences for the enjoyment of human rights." 181

\section{The OIC's Active Emphasis on Family Values is a Recent Phenomenon}

The OIC's 2005 Ten Year Program of Action identified the need to "[a]ccord necessary attention to the family as the principal nucleus of the Muslim society, [and to] exert all possible efforts . . . to face up to the contemporary social challenges confronting the Muslim family and affecting its cohesion, on the basis of Islamic values." 182 To this end, the Program called for establishing

\footnotetext{
178 The foundation for this vision, traced back to the CDHRI, already signals a departure from the UDHR. Among other things, the CDHRI makes the formation of family contingent on marriage and authorizes states to restrict the right to marriage based on religion: "The family is the foundation of society, and marriage is the basis of its formation. Men and women have the right to marriage, and no restrictions stemming from race, color or nationality shall prevent them from enjoying this right." CDHRI, supra note 16, art. 5(a). In contrast, the UDHR states: "Men and women of full age, without any limitation due to race, nationality or religion, have the right to marry and to found a family. They are entitled to equal rights as to marriage, during marriage and at its dissolution." UDHR, supra note 2, art. 16(1). Certain interpretations of Islam take a particularly rigid view of family. According to Farhat Haq, one of the obstacles preventing "fruitful dialogue on the issue of women's equality is the cultural centrality of the family in the Muslim world. For Islamic fundamentalists, the adoption of the Western model of the family is to commit cultural suicide." Farhat Haq, Jihad Over Human Rights, Human Rights as Jihad: Clash of Universals, in Negotiating CultuRE AND Human Rights 242, 253 (Lynda S. Bell et al., 2001). Given that Islam's conception of the family represents "a microcosm of the desired moral order," any challenge or critique of its structure and role "provokes deep anxieties." Id.

${ }^{179}$ A detailed treatment of the deleterious impact the OIC's version of Islamic family values may have on the rights of the child and refugee must be reserved for another occasion.

180 OIC Res. 4/42-C, pmbl. (May 27-28, 2015).

${ }^{181}$ Rep. of the U.N. High Comm'n for Human Rights, Discrimination and Violence Against Individuals Based on Their Sexual Orientation and Gender Identity, ๆ 66, U.N. Doc. A/HRC/29/23 (May 4, 2015).

182 OIC Ten Year Program, supra note 41, art. 2(VI)(9).
} 
a Family Affairs division within the OIC's General Secretariat. 183 The OIC formally approved this objective four years later. ${ }^{184}$ In 2011 , the organization reaffirmed its new family-rights oriented focus, modifying the title of its annual resolution on "Cultural and Social Affairs" to "Cultural, Social and Family Affairs." 185

The OIC's emphasis on family values gained concrete expression in 2015 . For the first time, its annual resolution on Social and Family Affairs introduced a provocative new section entitled "Safeguarding the values of the marriage and family institutions." ${ }^{186}$ The resolution rejected a 2014 UN Human Rights Council ("UNHRC") resolution on SOGI rights as being "in total contradiction with the teachings and values of Islam and other divine religions and with the human common sense." 187 It further invited the OIC Secretary General and IPHRC to "take necessary measures" to repeal the resolution. 188 The OIC's first "Ministerial Conference on Strengthening Marriage and Family Institution and Preserving its Values in Member States," held in 2017, reinforced the positions staked out in 2015. ${ }^{189}$ The significance of both these events is discussed in greater detail below, ${ }^{190}$ but their substance has set the stage for open-ended conflict at the UN over the issue of protection of the family, and more broadly, the recognition of SOGI-related rights.

\section{Protecting an "Ideal Family" Demands Conformity with OIC Religious Views Rather than International Reality}

The OIC's structural efforts to orient itself more robustly towards a defense of "Islamic family values" into the late 2010s are reinforced by the IPHRC's work, OIC Secretary General statements, and by OIC advocacy efforts at the UN. In 2015, the IPHRC held its 7th session, organized around the theme of "protection of family values." The session concluded that "the growing trend of confusing the definition of family with new and controversial notions of LGBT families ... that were neither universal nor recognized by international human

\footnotetext{
${ }^{183} I d$. art. 2(VI)(10).

${ }^{184}$ OIC Res. 8/36 (May 23-25, 2009) (recognizing "the need for the Muslim family to have a comprehensive mechanism to help it counter the challenges it faces amid the current international changes, and for strengthening the capacity of Member States to keep pace with issues related to the various segments of the family.").

185 Prior to 2011, the OIC generally passed an annual resolution "On Social Issues." Beginning in 2011, this resolution's title changed to "On Social and Family Issues." Compare OIC Res. 3/37-C (May 18-20, 2010) with OIC Res. 4/38-C (June 28-30, 2011).

186 OIC Res. 4/42-C, supra note 180, ๆ A.

${ }^{187} I d$. pmbl.

${ }^{188} I d$ ๆ $2-3$.

189 Ministerial Conference on Strengthening Marriage and Family Institution, OIC, https://www.oic-oci.org/confdetail/?cID=5\&lan=en (last visited Nov. 21, 2018).

190 See infra Parts III(C)(2) and III(D)(3).
} 
rights standards" 191 was diametrically opposed to the Koran's "good society." In the IPHRC's words, this "good society" could "only be achieved through the marriage between man and woman as husband and wife .... Any practice that potentially threathen [sic] the integrity of the family should not be seen as part of 'freedom of choice."' 192

While the IPHRC arguably may have demonstrated some willingness to recognize certain "non-traditional" family arrangements that break from its "[i]deal family consist[ing] of husband and wife," 193 it rejected outright the possibility that a family could be made up of two men or two women who love each other, or that such a familial unit could be entitled to the same protection afforded to "a long-term consensual relationship between a man and a woman who are bound by the reciprocal rights and responsibilities enshrined in Islamic teachings." 194

As part of his remarks to this IPHRC gathering, then Secretary General Madani asserted that protection of family values is of "utmost importance" to the OIC and that the organization's institutions must work to incorporate an "Islamic perspective on the interrelated subjects and project] unified views and positions." 195 To this end, the OIC continued to take measures at the UN to advance the organization's particular vision of family. Most notably as part of this effort, the OIC pushed two contentious resolutions on "Protection of the Family" through the UNHRC between 2014-15. ${ }^{196}$ The first resolution, passed

191 Press Release, OIC, OIC Independent Permanent Human Rights Commission (IPHRC) Concludes its 7th Session in Jeddah Held From 19-23 April 2015 (Apr. 23, 2015) (“[F]uture plans and projects that the Commission intends to deliberate upon, [include] ... strengthening research and writing reports / position papers on the ... issue of sexual orientation. ...”).

192 Press Release, OIC, IPHRC Reaffirmed the Importance of Family as the Natural and Fundamental Unit of Society that is Entitled to Protection by State and Society, During its Thematic Debate on "Protection of Family Values" (Apr. 21, 2015) [hereinafter IPHRC Thematic Debate on "Protection of Family Values"].

${ }^{193} I d$. For example, the IPHRC acknowledged that a "single-parent family, especially womanheaded family" might be accommodated-though not legitimated-"as the consequence of divorce and other factors." Id.

${ }^{194} I d$.

195 OIC Independent Permanent Human Rights Commission (IPHRC) concludes its 7th Regular Session in Jeddah held from April 19-23, 2015. The IPHRC's chairperson previously affirmed the Commission would work closely with the OIC's Figh Academy "to correct the misperceptions regarding the rights of women and children in Islam, as well as the protection of the family." Press Statement, M.K. Ibrahim, IPHHRC Chairperson, Concluding Statement at the Sixth Session of IPHRC (Nov. 6, 2014). The International Islamic Fiqh Academy (IIFA) is a subsidiary organ of the OIC created in 1981 and based in Jeddah, Saudi Arabia. It is tasked with studying "contemporary problems from the Sharia point of view and [trying] to find the solutions in conformity with the Sharia through an authentic interpretation of its content." Subsidiary Organs, OIC, https://www.oic-oci.org/page/?p_id=64\&p_ref=33\&lan=en\#FIQH (last visited Nov. 21, 2018).

196 See generally Human Rights Council Res. 26/11 (July 16, 2014); Human Rights Council Res. 29/22 (July 22, 2015). 
in 2014 with all fourteen OIC UNHRC members voting in favor, ${ }^{197}$ was mainly procedural in nature. It called for holding a panel discussion on protection of the family as well as preparing a report on that discussion. ${ }^{198}$ At the time, those states opposed to the resolution expressed concern over its substance because it "did not refer to family diversity and the individual rights of family members." 199

The following year, shortly after conclusion of the IPHRC's 7th session, Egypt introduced a second "Protection of the Family" draft resolution cosponsored by over $80 \mathrm{UN}$ member states including the African Group and 55 OIC states. ${ }^{200}$ In the Egyptian ambassador's words, UNHRC Resolution 29/22 represented a "comprehensive substantive omnibus draft resolution on protection of the family . . . building on . . . 2014's procedural resolution." ${ }^{201}$ It also represented a significant push to entrench a narrow view of what constitutes family. On this basis, it established which families merit protection of the state. For example, in urging States to provide the family "with effective protection and assistance" 202 in the face of "increasing vulnerabilities," 203 the resolution recognized only "single-headed households, child-headed households and intergenerational households" as being "particularly vulnerable to poverty and social exclusion." 204

To fully capture the OIC's effort to protect only selective forms of family that comport with its idealized "good society," consider the content of UNHRC Resolution 29/22. This resolution excluded from recognition (or particular vulnerability), among others, "families comprising (LGBTI) persons; extended families; self-created and self-defined families; families without children; families of divorced persons . . . and non-traditional families resulting from interreligious, intercommunity or inter-caste marriages." ${ }^{205}$ Other UNHRC

\footnotetext{
${ }^{197}$ Including the fourteen OIC states, twenty-six states in total voted in favor of the resolution, fourteen voted against, and six abstained.

198 H.R.C. Res. 26/11, supra note 196, ๆๆ 1-2.

199 U.N. High Commissioner for Human Rights, Summary of the Human Rights Council Panel Discussion on the Protection of the Family, ๆ 23, U.N. Doc. A/HRC/28/40 (Dec. 22, 2014).

200 Human Rights Council Res. 29/22, (July 1, 2015). Albania did not co-sponsor the resolution and was the only OIC state to vote against it. Palestine had no vote. All members of the Arab Group are OIC member states. Id.

${ }^{201}$ H.E. Ambassador Amr Ramadan, Introduction of Draft Resolution L.25 "Protection of the Family," 3 (July 2, 2015) (on file with the author).

${ }^{202}$ H.R.C. Res. 29/22, supra note 196, ๆ 20.

${ }^{203} I d$. ๆ 8.

204 Id. ๆ 16.

${ }^{205}$ U.N. High Commissioner for Human Rights, Report of the Working Group on the Issue of Discrimination Against Women in Law and in Practice, - 23, U.N. Doc. A/HRC/29/40 (Apr. 2, 2015). The Working Group observed that while "several international forums recognize family diversity, including 'in different cultural, political and social systems', many . . . non-traditional forms of family are not recognized by all States." Id. $\uparrow 24$.
} 
members took note of the challenge posed to the international human rights regime by the OIC's narrow approach. For example, while acknowledging that families can make a valuable contribution to strengthening society, the European Union (EU) members opposed the resolution because it "fail[ed] to recognize a basic and undeniable matter of fact-that in different cultural, political and social systems, various forms of the family exist. The recognition of the diversity of family forms is an essential element that this text lacks." 206

In addition to favoring only certain "traditional" families, UNHRC Resolution 29/22 also purported to connect "policies and measures to protect the family" to the existing regime designed to protect and promote the human rights of its individual members. ${ }^{207}$ Thus, not unlike the OIC's effort to place protection for religion ahead of individual rights, ${ }^{208}$ the resolution would install a narrow definition of family and prioritize it ahead of other families as well as at the expense of protecting existing individual rights. Endorsing such an approach is problematic for two reasons. First, it provides states with cover for pursuing general policies that downgrade or discount individual human rights and other family models in the name of protecting an idealized family unit. Second, it exposes those individuals subject to human rights abuses generated in the context of family to the risk of greater harm ${ }^{209}$ while signaling a grant of impunity to those who would perpetrate such violations. ${ }^{210}$

206 Protection of the Family: European Union Explanation of Vote (Jun. 22, 2017) (on file with the author).

${ }^{207}$ H.R.C. Res. 29/22, supra note 196, ๆ 17.

208 See Blitt, supra note 63.

${ }^{209}$ For example, "[w]omen and girls worldwide continue to experience violence most frequently in family contexts. Child abuse, including sexual abuse, is most commonly perpetrated by family members. Persons with disabilities also experience coercion and abuse in the family." Protection of the Family: A Human Rights Response, AWID (Mar. 24, 2015), https://www.awid.org/publications/protection-family-human-rights-response. This reality underscores the difficulty with attempting to ascribe rights to the family itself as against the individual rights-holders-namely children, women, etc.-who comprise it. Id.

${ }^{210}$ For example, LGBTI youth reported higher rates of abuse within family structures and associated familial rejection behavior had negative consequences on their health. Sabra L. KatzWise et al., Lesbian, Gay, Bisexual, and Transgender Youth and Family Acceptance, 63 PEDIATRIC CliNIC NORTH AM. 1011, 1014 (2016) (finding "relative to heterosexual peers, sexual minorities report . . increased rates of parental abuse, and homelessness. Transgender youth also report elevated rates of child abuse compared to cisgender peers.") (internal notes omitted); see Caitlin Ryan et al., Family Rejection as a Predictor of Negative Health Outcomes in White and Latino Lesbian, Gay, and Bisexual Young Adults, 123 PEDIATRICs 346 (2009) (finding a "clear link between specific parental and caregiver rejecting behaviors and negative health problems in young lesbian, gay, and bisexual adults", including higher rates of suicide, depression, illegal drug use, and unprotected sexual intercourse, when compared "with peers from families that reported no or low levels of family rejection."); see also Jennifer S. Hirsch, A Scientific Look at the Damage Parents Do When They Bully Their Gay Kids, WASH. Post. (Apr. 14, 2015), https://www.washingtonpost.com/posteverything/wp/2015/04/14/a-scientific-look-at-the-damageparents-do-when-they-bully-their-gay-kids/?utm_term=.db7f87488a39 ("Kids lacking parental support for their sexual orientation are at higher risk for mental health problems, drug use, and unprotected sex.”); Jessica Valenti, Homophobic, Transphobic Parents Make Abusive Homes. Let's
Help
$L G B T$
Kids
Get
Out,
GUARDIAN
(Jan.
5 ,
2015), 
Finally, Resolution 29/22 also tasked the OHCHR with preparing a report on state obligations to protect the family. Ironically, the substance of this report is likely to engender strong OIC opposition ${ }^{211}$ since its chief finding refutes the application of any narrow, "traditional" definition for family. According to the OHCHR, the international community must:

recognize the diverse and changing forms of the family institution, in accordance with the different social, cultural and economic characteristics of every society; the promotion of equality between men and women; and the effective protection and promotion of the rights of women, children, persons with disabilities, older persons and all family members, without distinction. Moreover, ensuring universal access to sexual and reproductive health services, including family planning, should be an integral part of development efforts. ${ }^{212}$

Ultimately, the OHCHR report observed that while states preserve "some leeway" to define the concept of family under national law that may consider various "religions, customs or traditions within their society," international law establishes "at least two minimum conditions for the recognition and protection of families at the national level." ${ }^{213}$ These two conditions are: "respect for the principle of equality and non-discrimination...[and] the effective guarantee of the best interest of the child." ${ }^{214}$ Alongside these

https://www.theguardian.com/commentisfree/2015/jan/05/homophobic-transphobic-parentsabusive-homes-lgbt-kids ("For a young LGBT person, living with a rampantly homophobic or transphobic guardian ... means enduring child abuse.").

${ }^{211}$ For a baseline, consider the reaction of C-Fam, a self-described "pro-family" NGO, to the OHCHR report. The organization criticized the report for its "progressive, and aggressive, attempt to expand the meaning of family in international law and policy to include same-sex relationships." Stefano Gennarini, UN Report: "There Is No Definition of the Family," CTR. FOR FAM. \& HUM. RTS. (Jan. 29, 2016), https://c-fam.org/friday_fax/un-report-no-definition-family/. C-Fam previously labeled Resolution 29/22 a "big win" and "monumental development for the pro-family movement." Rebecca Oas, Big Win for Traditional Family at UN Human Rights Council, CTR. FOR FAM. \& HUM. RTS. (July 9, 2015), https://c-fam.org/friday_fax/big-win-for-traditional-family-at-un-humanrights-council/. C-Fam is the type of NGO IPHRC refers to when it recommends "undertaking advocacy activities at relevant forums, including working with pro-family NGOs for holding conferences and seminars with the view to promoting and advancing family values." IPHRC Thematic Debate on "Protection of Family Values," supra note 192.

${ }^{212}$ U.N. High Commissioner for Human Rights, Protection of the Family: Contribution of the Family to the Realization of the Right to an Adequate Standard of Living for its Members, Particularly Through its Role in Poverty Eradication and Achieving Sustainable Development, 9 76, U.N. Doc. A/HRC/31/37 (Jan. 2016), https://www.ohchr.org/EN/HRBodies/HRC/RegularSessions/Session29/Pages/ResDecStat.aspx [hereinafter Protection of the Family].

${ }^{213} I d$. 26.

${ }^{214} I d$. (internal citations omitted). For example, the UN Committee on the Rights of the Child "has called upon States to protect children from discrimination based on their own or their parents' or legal guardian's sexual orientation or gender identity." Further, the UNCRC prohibits all forms of abuse of children, including "based on their gender, sexual orientation or disability." Id. ๆๆ 42, 44 . 
minimum requirements, international treaty bodies have elaborated supplemental state obligations, such as the need to protect specific forms of the family-including same-sex couples and de facto unions-because of "the vulnerability of their members" to potential human rights abuses. ${ }^{215}$ In light of these findings, the OHCHR report concluded that any implementation of protection measures for family at the national level "should be guided by basic human rights principles, including equality and non-discrimination, and by respect for the rights of individual family members, notably those who might find themselves in a situation of vulnerability." 216

The OHCHR report reflects precisely the kind of balanced, inclusive, and individual rights-respecting policy for family protection that the OIC-by prioritizing religious and traditional norms-is attempting to short-circuit. And while this OIC campaign may have secured the support of a UNHRC majority, it is so antithetical to existing international human rights norms that it engendered an unexpected opponent: a UNHRC-established expert working group. Confronted with Resolution 29/22, the UN Working Group on Discrimination Against Women unequivocally concluded that its content "threaten[s] to undermine international achievements in the field of human rights in the name of cultural and religious diversity." 217

215 Id. 9 27. While IHRL may not require states to permit same-sex couples to marry, "the obligation to protect individuals from discrimination on the basis of sexual orientation extends to ensuring that unmarried same-sex couples are treated in the same way and entitled to the same benefits as unmarried opposite-sex couples." U.N. High Commissioner for Human Rights, Discriminatory Laws and Practices and Acts of Violence Against Individuals Based on their Sexual Orientation and Gender Identity, $\mid$ 68, U.N. Doc. A/HRC/19/41 (Nov. 17, 2011). Likewise, the UN Working Group on Discrimination Against Women has concluded "that the understanding and legal definition of the family in national legislation should be extended to recognize different forms of family", including "recognition of same-sex couples, for both women and men." Report of the Working Group on the Issue of Discrimination Against Women in Law and in Practice, supra note 205 , ๆ 25.

216 Protection of the Family, supra note 212 , ๆ 50.

${ }^{217}$ Report of the Working Group on the Issue of Discrimination Against Women in Law and in Practice, supra note 205, I 19. For its part, the OIC regretted the Working Group's "attempts to redefine the universally established notion of family which is firmly rooted in International Human Rights Law. We believe that it is beyond the mandate of the Working Group to criticize [sic] resolution on family which was the outcome of inter-governmental negotiations and was adopted by [the] Human Rights Council." Press Statement, Statement by Pakistan on Behalf of OIC During the Interactive Dialogue with the Special Rapporteur on Extrajudicial, Summary or Arbitrary Executions and Working Group on the Issue of Discrimination Against Women in Law and in Practice (June 19, 2015) (on file with the author). The Working Group also was highly critical of UNHRC Resolution 16/3 on promoting human rights and fundamental freedoms through a better understanding of traditional values of humankind. This contentious resolution can be traced back to 2009. At the time, it faced stiff opposition by the EU and others who argued incorporating the "concept of traditional values...could render human rights more vulnerable...[and] could be used to weaken human rights, as enshrined in international instruments." Human Rights Council Adopts Six Resolutions and One Decision on Discrimination Against Women and Freedom of Expression, Among Others, ReLIEFWeB (Oct. 2, 2009), http://reliefweb.int/report/myanmar/human-rights-council-adopts-six-resolutions-and-one-

decision-discrimination-against. This risk is genuine. For example, the government of Iran "has actively sought to justify paternalism and gender-inequality under the guise of traditional values 
Despite the OHCHR report and vocal opposition from UN working groups, the OIC has pressed forward as the primary engine advocating "protection of the family" resolutions at the UNHRC. In 2016 and 2017, two additional contentious resolutions sought to perpetuate a narrow definition of the types of families worthy of protection. ${ }^{218}$ These resolutions retain problematic language validating support for the narrow list of families previously identified as being "particularly vulnerable to poverty and social exclusion." 219 Further, they urge states to provide these specific types of families "with effective protection, support and assistance." ${ }^{220}$ Like Resolution 29/22, the subsequent resolutions similarly reiterate recognition that the family "plays a crucial role in the preservation of cultural identity, traditions, morals, heritage and the values system of society," 221 and that the "family unit is facing increasing vulnerabilities and pressures." 222

States opposed to the OIC's most recent protection of the family resolutions have continued to argue they fail to "support all families, in all their diverse forms," and similarly fail to place "sufficient emphasis on the protection of the rights of individuals within families." 223 During negotiations over the proposed 2017 resolution text, the European Union sponsored an amendment that would have added a provision "[r]ecogniz[ing] that, in different cultural, political and social systems, various forms of the family exist." ${ }^{224}$ The proposal-seeking only to restate the OHCHR's conclusion-failed by a recorded vote 19 to 22 , with five abstentions. In explaining its vote against the final 2017 resolution, the EU called out the main sponsors as refusing "to accommodate key concerns, particularly around the importance of recognising that various forms of the

and cultural relativism." Letter by Women's Rights Activists to Members of the United Nation's Economic and Social Council, UNPO (Apr. 28, 2010), http://www.unpo.org/content/view/11047/89/. Over 200 Iranian human rights activists and seven women's rights organizations endorsed the letter. For more on Russia's role in advancing the original "traditional values" resolution and its impact at the UN, see generally Robert C. Blitt, Russia's 'Orthodox' Foreign Policy: The Growing Influence of the Russian Orthodox Church in Shaping Russia's Policies Abroad, 33 U. PA. J. INT'L L. 363 (2012).

${ }^{218}$ Human Rights Council Res. 35/13 (July 6, 2017); see also Human Rights Council Res. 32/23 (July 18, 2016).

${ }^{219}$ Compare H.R.C. Res. 35/13, supra note 218, ๆ 14 with H.R.C. Res. 32/23, supra note 218, ๆ 9. However, both resolutions do add "families with members with disabilities" to the enumerated list introduced under H.R.C. Res. 29/22. See id.; H.R.C. Res. 35/13, supra note 218; H.R.C. Res. 32/23, supra note 218.

${ }^{220}$ H.R.C. Res. 35/13, supra note 218, ๆ 26; H.R.C. Res. 32/23, supra note 218, ๆ 20.

${ }^{221}$ H.R.C. Res. 35/13, supra note 218, ๆ 12; H.R.C. Res. 32/23, supra note 218, ๆ 7.

${ }^{222}$ H.R.C. Res. 35/13, supra note 218, ๆ 14; H.R.C. Res. 32/23, supra note 218, ๆ 9.

${ }^{223}$ U.N. Human Rights Council, Slovenia: Explanation of Vote on L.35-Protection of the Family, and Amendments Thereto (L.82, L.83, L.84, L.89) (on file with the author).

224 Rep. of the U.N. Human Rights Council, Amendment to Human Rights Council Draft Resolution A/HRC/35/L.21, U.N. Doc. A/HRC/35/L.45 (Jun. 20, 2017) (voted at 35th meeting, Jun. $22,2017)$. 
family exist." 225 From the EU's perspective, the resolution's overall approach "place[d] emphasis on the protection of the family rather than on the international legal obligations of states to promote and protect the human rights of individual family members, who are the rights holders." Furthermore, the final text risked allowing "traditional values or customs [to] undermine the fundamental, universal nature of human rights or indeed hinder progress to address harmful practices such as child, early and forced marriage or female genital mutilation." 226

In addition to opposing the views of western states, the OHCHR, and the UN Working Group on Discrimination Against Women, the OIC's lobbying on protection of the family also clashes with the positions staked out by various Muslim activists and scholars. For example, Musawah, "a global movement for equality and justice in the Muslim family," 227 believes that "[s]pecific attributes and roles should not be assigned on the basis of gender, but on what is good for the family as a whole, and on dignity and respect for every member." The organization maintains that this position is "possible from within Muslim legal tradition." ${ }^{228}$ Kecia Ali has likewise challenged the basis for the OIC's "traditional" family, positing that such a framing is premised not on religious necessity but rather on "cultural assumptions shared by the [Muslim] jurists as a result of their social location in a particular and . . . particularly patriarchal environment." 229 She concludes:

[A] thorough exploration and analysis of traditional jurisprudence [reveals] the extent to which its rules are seriously flawed; they cannot be Divine ... This system is the result of an interpretation, indeed of numerous acts of interpretation, by particular men living and thinking at a specific time. Their jurisprudence is shaped ... by the assumptions and constraints of the time in which it was formulated. ${ }^{230}$

Writing on the issue of family nearly thirty years ago, An-Na'im observed that the:

${ }^{225}$ Protection of the Family: European Union Explanation of Vote (Jun. 22, 2017) (on file with the author).

${ }^{226} I d$.

${ }^{227}$ About Musawah, MUSAwAH, http://www.musawah.org/about-musawah (last visited Nov. 21, 2018).

228 Vision for Family, MUSAWAH, 12-13, http://www.musawah.org/sites/default/files/MusawahVisionFortheFamily.pdf (last visited Nov. 21,2018 ) (failing to reference or explicitly address equality for families with same-sex partners or protection for LGBTI individuals within the family context).

${ }^{229}$ Ali, supra note 144, at 169. Aligned with this, progressive Muslim scholars maintain "that there can be no long-lasting and sustainable gains in women's rights unless patriarchal notions of family and gender relations are debated, challenged, and redressed within an Islamic framework." Adis Duderija, Progressive Islam: Reawakening Authenticity, 33 TIKKUn 66, 70 (2018).

230 Ali, supra note 144, at 183. 
[C]ontrol which Shari'a exercises over the private realm of home and family is so entrenched, and its violation of human rights so clear, that it may explain in part why some Muslim countries refuse to ratify the relevant human rights instruments or at least entered reservations on their obligations under certain human rights treaties. ${ }^{231}$

As demonstrated below, the clash over sexual orientation is not reserved to the debate over family protection. Rather, it spills over into more sweeping and general areas that impact basic questions of individual equality and nondiscrimination.

\section{B. OIC Denial of SOGI Equality and Nondiscrimination Transcends Protection of the Family}

While the specter of same sex marriage may be a central motivating factor for the OIC's campaign to preserve traditional family values, the organization's opposition to SOGI-related rights predates its relatively recent foray into protection of the family. An examination of OIC positions on a wide range of human rights issues unrelated to family protection illustrates that its rejection of SOGI rights is not merely a byproduct of a desire to protect the family, but rather embodies a core component of the organization's wider advocacy efforts.

1. Multiple OIC Justifications for Rejecting SOGI Recognition Combine to Deplete Right to Highest Attainable Standard of Health

The OIC's rejectionist approach to the full basket of freedoms and entitlements associated with the right to the highest attainable standard of health, coupled with its rejection of SOGI-related vulnerabilities in the context of combatting HIV/AIDS, confirms that the organization's opposition to SOGI cannot be explained based on protection of the family alone. Universal recognition of the right to the highest attainable standard of health flows from a variety of international sources, including the UDHR ${ }^{232}$ and ICESCR, with the latter expressly "recogniz[ing] the right of everyone to the enjoyment of the highest attainable standard of physical and mental health." ${ }_{233}$ Sexual and reproductive health ("SRH") is recognized as an "essential" or "integral" component of this universal right. ${ }^{234}$ According to the Committee on Economic,

\footnotetext{
${ }^{231}$ An-Na'im, supra, note 145, at 41.

232 "Everyone has the right to a standard of living adequate for the health and well-being of himself and of his family." UDHR, supra note 2, art. 25(1).

${ }^{233}$ G.A. Res. 2200A (XXI), art. 12(1) (Dec. 12, 1966).

${ }^{234}$ U.N., Econ., Soc., \& Cultural Rts., General Comment No. 22 (2016) on the Right to Sexual and Reproductive Health, I 1, U.N. Doc. E/C.12/GC/22 (May 2, 2016) [hereinafter Comment No. 22]. For a good summary detailing how IHRL protects reproductive rights, see UNITED NATIONS Population Fund et al., Reproductive Rights aRe Human Rights: A Handbook For NATIONAL HUMAN RIGHTS INSTITUTIONS $21-22, \quad 72-74 \quad$ (2014), http://www.ohchr.org/Documents/Publications/NHRIHandbook.pdf (a joint publication of United
} 
Social and Cultural Rights ("CESCR"), the right to SRH includes the freedom "to make free and responsible decisions and choices, free of violence, coercion and discrimination, regarding matters concerning one's body and sexual and reproductive health," as well as the entitlement to "unhindered access to a whole range of health facilities, goods, services and information." 235

In the context of OIC efforts to protect a traditional vision of the family governed by patriarchal concepts and other narrow values, SRH rights are rendered particularly vulnerable. This vulnerability is exacerbated because the family itself is harnessed as a forum and instrument for such violations. ${ }^{236}$ As one commentator has observed:

Often sexism and homophobia combine to restrict sexual rights. For many conservative, "religious right," or "fundamentalist" actors, affording women the rights to bodily integrity, to autonomy, and to the ability to make their own decisions about reproduction all risk the downfall of "the family," the community, and even the state. ${ }^{237}$

As is the case with other rights, "[t]he right to [SRH] is also indivisible from and interdependent with other human rights" enshrined elsewhere under international law. ${ }^{238}$ Already as early as 2000, the CESCR explicitly recognized that the ICESCR:

$[\mathrm{P}]$ roscribe $[\mathrm{d}]$ any discrimination in access to health care and underlying determinants of health, as well as to means and

\footnotetext{
Nations Population Fund, Office of the United Nations High Commissioner for Human Rights, and Danish Institute for Human Rights).

${ }^{235}$ Comment No. 22, supra note 234 , ๆ 5.

${ }^{236}$ U.N. High Commissioner for Human Rights, Sexual and Reproductive Health and Rights, http://www.ohchr.org/EN/Issues/Women/WRGS/Pages/HealthRights.aspx (last visited Nov. 21, 2018). Prioritizing the family degrades the individual right to SRH in a variety of ways. See, e.g., World Health Org., SeXual Health, Human Rights AND the LaW 35 (2015) (noting that it may facilitate "[s]exual and sexuality-related violence . . . as a form of punishment and control" and facilitate so-called "honor crimes" or "honor killings"); Carmel Shalev, Expert Member, Convention on the Elimination of All Forms of Discrimination Against Women, Rights to Sexual and Reproductive Health-the ICPD and the Convention on the Elimination of All Forms of Discrimination Against Women, UNITED NATIONS (Mar. 18, 1998), http://www.un.org/womenwatch/daw/csw/shalev.htm (noting it may impose spousal authorization for certain reproductive health procedures); Protection of the Family: A Human Rights Response, supra note 209 (noting it may facilitate forced marriages or child marriages).

${ }^{237}$ Susana T. Fried, Sexuality and Human Rights, 7 HEALTH \& Hum. RTS. 273, 274 (2004).

${ }^{238}$ Comment No. 22, supra note 234, $\uparrow 10$ (elaborating a principle previously expressed regarding the encompassing right to the highest attainable standard of health); see also U.N., Econ., Soc., \& Cultural Rts., Substantive Issues Arising in the Implementation of the International Covenant on Economic, Social, and Cultural Rights: General Comment No. 14 on the Right to the Highest Attainable Standard of Health, If 3, U.N. Doc. E/C.12/2000/4, (Aug. 11, 2000) [hereinafter Comment No. 14] ("[t]he right to health is closely related to and dependent upon the realization of other human rights").
} 
entitlements for their procurement, on the grounds of race, colour, sex, language, religion, political or other opinion, national or social origin, property, birth, physical or mental disability, health status (including HIV/AIDS), sexual orientation and civil, political, social or other status, which has the intention or effect of nullifying or impairing the equal enjoyment or exercise of the right to health. 239

By extension, respect for non-discrimination in the context of the right to SRH similarly "encompasses the right of all persons, including lesbian, gay, bisexual, transgender and intersex persons, to be fully respected for their sexual orientation, gender identity and intersex status." 240 State parties to the ICESCR therefore "have an obligation to combat homophobia and transphobia, which lead to discrimination, including violation of the right to sexual and reproductive health." 241 This interdependence operates equally in the context of other rights. For example, combining SRH and nondiscrimination with the right to education generates a right to seek, receive and disseminate information and ideas on all aspects of SRH "that is comprehensive, nondiscriminatory, evidence-based, scientifically accurate and age appropriate."242 It further establishes a government obligation to provide such information "in a manner consistent with the needs of the individual and the community, taking into consideration, for example, age, gender . . . sexual orientation, gender identity and intersex status." 243

Beyond formal legal equality, fulfilling the right to non-discrimination and equality in the context of SRH also requires substantive equality. This entails addressing "the distinct sexual and reproductive health needs of particular groups, as well as any barriers that particular groups may face." ${ }^{244}$ In undertaking this obligation, states should provide "tailored attention" and care "in a respectful and dignified manner that does not exacerbate marginalization." 245 The CESCR cautions that LGBTI and other vulnerable groups risk "be[ing] disproportionately affected by intersectional discrimination in the context of sexual and reproductive health." 246 Consequently, states maintain an obligation to ensure that laws and policies effectively "prevent and eliminate discrimination, stigmatization and negative stereotyping that hinder[s] access to sexual and reproductive health." ${ }^{247}$ As

\footnotetext{
${ }^{239}$ Comment No. 14, supra note 238, ๆ 18.

${ }^{240}$ Comment No. 22, supra note 234, ๆ 23.

${ }^{241} I d$.

${ }^{242} I d$. 9.

${ }^{243} I d$. \ 19.

${ }^{244} I d$. $\mid 24$.

${ }^{245}$ Comment No. 22, supra note 234, $\mid 24$.

${ }^{246} I d$. \ 30.

${ }^{247} \operatorname{Id}$. ๆ 31.
} 
part of this obligation, states are expected to design measures intended "to overcome the often exacerbated impact that intersectional discrimination has on the realization of the right to sexual and reproductive health." 248

The UN's 2015 Sustainable Development Goals ("SDGs") 249 reiterate many of the SRH standards elaborated above. For example, under Goal 3, states undertake by 2030 to "ensure universal access to sexual and reproductive health-care services, including for family planning, information and education, and the integration of reproductive health into national strategies and programmes." 250 The SDGs also recognize that vulnerable groups, including people living with HIV/AIDS, "must be empowered." 251 To this end, states commit themselves to "accelerat[ing] the pace of progress made in fighting" communicable diseases such as HIV/AIDS and by 2030, ending the epidemic. ${ }^{252}$

The SDG's High Level Political Forums have also reinforced the urgent need for comprehensive education to combat HIV/AIDS based on the right to SRH:

1800 young people are newly infected with HIV every day. This underscores the importance of ensuring that young people can fully exercise their rights to access sexual and reproductive health and HIV information ... including . . . comprehensive sexuality education free from discrimination, coercion and violence. At the same time, key populations, including sex workers, people who inject drugs, transgender people and men who have sex with men remain at much higher risk of HIV infection and require access to comprehensive prevention services, including harm reduction. ${ }^{253}$

${ }^{248} I d$. ๆ 30.

${ }^{249}$ As part of this global effort, states adopted a set of 17 goals to end poverty, protect the planet, and ensure prosperity for all. G.A. Res. 70/1 (Sept. 25, 2015). A video by Japanese entertainer Pikotaro (AKA Daimaou Kosaka) highlights a few of the SDGs succinctly. Mofachannel, Pikotaro \& Ministry of Foreign Affairs [of Japan] (SDGs) PPAP, YoUTuBE (July, 12, 2017), https://www.youtube.com/watch?v=H519RHeATl0 (singing, among other things, "I have an apple. I have a pineapple ... no poverty!"); Japanese YouTube Star Piko Taro Makes First UN Appearance, Promotes Global Goals, UN NEWs CENTER (July 18, 2017), http://www.un.org/apps/news/story.asp?NewsID=57199\#.WXDh7MaZMUE.

${ }^{250}$ G.A. Res. 70/1, supra note 249, at 16 ("Goal 3. Ensure healthy lives and promotes well-being for all at all ages."). SRH is reinforced under Goal 5 ("Achieve gender equality and empower all women and girls."), which inter alia calls for "[e]nsur[ing] universal access to sexual and reproductive health and reproductive rights as agreed in accordance with the Programme of Action of the International Conference on Population and Development and the Beijing Platform for Action and the outcome documents of their review conferences." Id. at 18. The IPHRC appears to question the legitimacy of these outcome documents. See infra text accompanying note 259.

251 G.A. Res. 70/1, supra note 249, at 23.

${ }^{252}$ For the UN's position on the HIV/AIDS epidemic, see Goal 3.3. in G.A. Res. 70/1, supra note 249 , at 26 .

${ }^{253} 2017$ HLPF Thematic Review of SDG3: Ensure Healthy Lives and Promote Well-Being for All at All Ages, DEP'T ECON. \& Soc. AFFAIRS 4, (2017), 
Despite the abundance of recognized international norms elaborating on $\mathrm{SRH}$ rights, the OIC's IPHRC has seen fit to use its platform to elaborate on a contrary position that promotes the organization's parochial vision of an ideal family. Among other things, the IPHRC has promulgated the view "that a healthy and stable family [can] only be accomplished when husband and wife are considered equal in dignity and fundamental human rights both in the family and society" and that "Islamic values [are] the basis to carry out equal responsibilities and to enjoy basic rights within the families." 254 Elaborating on this vision, IPHRC member Mostafa Alaei characterized SRH rights as "a pure individualist, self-centered and egoistic vision" from which Muslim women must be emancipated. ${ }^{255}$ Rather than pursue the right to make free and responsible decisions concerning one's body and sexual and reproductive health, Alaei posits women should instead embrace the "different responsibilities" bestowed upon them under Islam and accept their obligation to "collaborate with men for the common and collective interest." 256

The IPRHC's reaction to the right to access comprehensive, nondiscriminatory, evidence-based, and scientifically accurate SRH information perfectly encapsulates the OIC's willingness to set aside individual rights in the name of protecting the traditional family. The IPHRC has attacked existing international norms relating to universal access to $\mathrm{SRH},{ }^{257}$ branding such efforts a threat to the Islamic conception of human rights. ${ }^{258}$ During a 2015 debate on the "Protection of Family Values," the IPHRC condemned what it labeled "the practice of promoting divisive and non-universal rights of comprehensive sexuality education to children, which include morally unacceptable concepts, behaviours and practices." 259 Further, it rejected UNdisseminated publications "that elaborate on the so-called notion of sexual orientation and comprehensive sexuality education for children," branding them "disturbing and morally unacceptable ... as well as potentially harmful to the very institution of family .... [and] undermining the spirit of the

\footnotetext{
https://sustainabledevelopment.un.org/content/documents/14367SDG3format-rev_MD_OD.pdf [hereinafter 2017 HLPF Thematic Review of SDG3].

${ }^{254}$ IPHRC Thematic Debate on "Protection of Family Values," supra note 192.

255 Mostafa Alaei, The Role of Muslim Modern Women, IPHRC, 4, http://www.oiciphrc.org/en/data/docs/articles/184501.pdf. Alaei's nine-page document appears to hold a place of pride for the IPHRC. It is the only article hosted on the IPHRC's website. Articles, IPHRC, http://www.oic-iphrc.org/en/articles (last visited Nov. 21, 2018).

${ }^{256}$ Compare ALAEI, supra note 255, at 5 (Alaei appears to question the validity of certain SRH rights outlined in paragraphs 94-96 of the Beijing Platform for Action), with UN WOMEN, BEIJING DeClaRATION AND PlatForm FOR ACTION, qा 94-96, (Sept. 4-15, 1995), http://beijing20.unwomen.org/ /media/headquarters/attachments/sections/csw/pfa_e_final_web.p df.

257 See discussion supra notes 235 and 250 and accompanying text.

258 See IPHRC Thematic Debate on "Protection of Family Values," supra note 192 and accompanying text.

${ }^{259}$ IPHRC Thematic Debate on "Protection of Family Values," supra note 192.
} 
universally accepted human rights values, norms and instruments." 260 In dismissing these materials-along with the state obligation to ensure comprehensive sexuality education-the "IPHRC called on all stakeholders, including UN mechanisms, NGOs and national human rights institutions to put the family at the core of their agendas as well as avoid the misconceptions and controversies, which contradict the universal family values."261

This problematic position corresponds with the OIC's approach to HIV/AIDS. For example, during a 2016 UN panel discussion on addressing human rights issues in the context of HIV/AIDS, Pakistan, on behalf of the OIC, failed to acknowledge any role for education in combatting this epidemic or fulfilling SRH-related human rights obligations. ${ }^{262}$ Instead, Pakistan invoked the UNGA's 2011 Political Declaration on HIV and AIDS to stress that "the sovereign rights of Member States" should dictate how HIV/AIDS policy plays out on the national level. ${ }^{263}$ Remarks made by Egypt are helpful in understanding Pakistan's prioritizing of the 2011 Political Declaration as a touchstone. ${ }^{264}$ In addition to reaffirming state sovereignty, the 2011 declaration also emphasized "the importance of cultural, ethical and religious values . . . in sustaining national HIV and AIDS responses" and "the central role of the family . . . in reducing vulnerability to HIV." 265 In the Egyptian representative's view, neglecting these values "to promote controversial social norms and issues such as sexual orientation ... [risked] weaken[ing] the global partnership to accomplish our common objective." 266

The IPHRC's rejection of universal, comprehensive SRH education as undermining its conception of the ideal family confirms that the OIC's advocacy in this arena goes beyond imposing restrictions on women's equality. More exactly, the quest to safeguard Islamic family values also entails a

${ }^{260} I d$.

${ }^{261} I d$.

262 Press Statement, Comments by Ambassador of Pakistan on Behalf of OIC, Panel Discussion on the Progress in and Challenges of Addressing Human Rights Issues in the Context of Efforts to End the HIV/AIDS Epidemic by 2030, (Mar. 21, 2016), https://extranet.ohchr.org/sites/hrc/HRCSessions/RegularSessions/31stSession/OralStatements/2 _Pakistan_OIC_HIV_mtg_30.pdf. The statement focused exclusively on reducing costs associated with antiviral medicines and treatment. $I d$.

${ }^{263} I d$.

${ }^{264}$ G.A. Res. 65/277 (July 8, 2011)

265 Id. ๆๆ $38,43$.

266 Press Statement, Comments by the Representative from Egypt, Panel Discussion on the Progress in and Challenges of Addressing Human Rights Issues in the Context of Efforts to End the HIV/AIDS Epidemic by 2030, (Mar. 11, 2016), https://extranet.ohchr.org/sites/hrc/HRCSessions/RegularSessions/31stSession/OralStatements/8 Egypt_HIV_mtg_30.pdf. Though it reaffirmed the 2001 Declaration, the 2016 Political Declaration on HIV and AIDS, endorsed three months after this UN panel discussion, eliminated references to the family and religion alluded to by the Egyptian representative. See G.A. Res. 70/266, at 2 (June 22, 2016). 
wholesale rejection of what the Commission derisively terms "so-called" sexual orientation, as well as undercutting the rights of children. ${ }^{267}$ In essence, the denial of equality and nondiscrimination protections for the LGBTI community is a sine qua non of OIC advocacy to protect the family.

At the same time, the OIC's posture on other issues still relating to $\mathrm{SRH}$ indicate that its contempt for SOGI rights comes with supplemental justifications beyond the narrow emphasis on protection of the family. For example, the OIC's 2016 letter to the UN General Assembly President expressed its displeasure at the possibility that eleven select NGOs, which "focus on gay, lesbian or transgender rights," 268 might participate in the UNsponsored 2016 High-Level Meeting on Ending AIDS. ${ }^{269}$ Without any reference to protection of the family-or for that matter providing any explicit justification for opposing their presence-the OIC requested that these groups, including organizations "from far-flung countries that are not part of the Islamic bloc," 270 be barred from attending the conference. ${ }^{271}$

Organizers of the High-Level Meeting billed the event as a gathering of "world leaders, government representatives, HIV programme implementers and civil society organizations from across the world," intended to advance the UN's SDGs and "to chart the way forward to ending AIDS as a public health threat by 2030." 272 At the very least, to imply LGBTI-affiliated NGOs lacked a legitimate interest in participating in this event is deeply worrisome. More disconcertedly, the OIC's action ran afoul of the Greater Involvement of People

${ }^{267}$ IPHRC Thematic Debate on "Protection of Family Values", supra note 192.

${ }^{268}$ Michael Astor \& Edith M. Lederer, Muslim Nations Block Gay Groups from UN AIDS Conference, Associated Press (May 18, 2016), https://apnews.com/865ff6ccc7f048de8244225948101557. The NGOs were based in "Egypt, Estonia, Guyana, Jamaica, Kenya, Peru, Thailand, Ukraine, Africa and the United States." Id.

${ }^{269}$ Among other goals, the meeting intended to "focus the world's attention on the importance of a Fast-Track approach to the AIDS response over the next five years" to eliminate HIV-related discrimination. U.N.G.A., 2016 High-LEVEL MEETING ON ENDING AIDS, 5 (June 8-10, 2016), http://www.unaids.org/sites/default/files/media_asset/2016HighLevelMeeting_en.pdf.

270 Somini Sengupta, U.N. AIDS Meeting Faces Dispute Over 22 Barred Groups, N.Y. TIMES (May 18, 2016), http://www.nytimes.com/2016/05/19/world/aids-un-gay-transgender.html?_r=1.

271 James Rothwell, Muslim Countries Ban Gay and Transgender Reps from United Nations Meeting on AIDS, TELEGRAPH (May 18, 2016), http://www.telegraph.co.uk/news/2016/05/18/muslim-countries-ban-gay-and-transgender-repsfrom-united-nation/. The OIC and other states had taken similar action in the past, including opposing UN stamps promoting LGBT equality and the extension of benefits to the same sex partners of UN employees. Muslim States Block 11 LGBT Groups from Attending UN AIDS Meeting, GUARDIAN (May 17, 2016), http://www.theguardian.com/world/2016/may/17/muslimstates-united-nations-lgbt-groups-aids-meeting [hereinafter Muslim States Block 11 LGBT Groups].

272 Press Statement, UNAIDS, UNAIDS Calls for Inclusion and Full Participation of Civil Society Organizations at the 2016 United Nations General Assembly High-Level Meeting on Ending AIDS (May 18, 2016), http://www.unaids.org/en/resources/presscentre/pressreleaseandstatementarchive/2016/may/201 60518_PS_inclusion_HLM. 
Living with HIV Principle ("GIPA") 273 and underscored the reality that "human rights defenders, including those living with HIV/AIDS, working to advance social justice and secure rights in the AIDS response across the world still face stigma, discrimination and violence." 274

Nevertheless, due to organizational rules surrounding the meeting, the General Assembly president complied with the OIC demand and barred the NGOs from participating directly in the meeting. ${ }^{275}$ A response letter filed by the United States objected to the decision: "Given that transgender people are 49 times more likely to be living with HIV than the general population, their exclusion from the high level meeting will only impede global progress in combatting the HIV/AIDS pandemic and achieving the goal of an AIDS-free generation." 276

The OIC's seemingly petty high-level intervention to exclude LGBTI groups from a conference aimed at defeating a deadly pandemic is emblematic of far graver discriminatory policies being perpetuated in OIC states. Notably, these policies - fueled by unchecked stigma - are detached from any rationale related to protection the family. They operate to deter LGBTI people from seeking health care with consequent "devastating effects." 277 They deny "recognition of the rights of the groups most affected [by HIV], including LGBT persons." 278 But perhaps more damning, they endorse actions that are antithetical to human rights, including "the use of pathologizing classifications for persons based on their sexual orientation and gender identity," that results

${ }^{273}$ See UNAIDS, Policy Brief: The Greater Involvement of People Living with HIV (GIPA) 1 (Mar. 2007), http://data.unaids.org/pub/briefingnote/2007/jc1299_policy_brief_gipa.pdf. Under GIPA, governments must "involve people living with HIV in developing funding priorities and in the choice, design, implementation, monitoring and evaluation of HIV programmes from their inception." Id. at 3.

${ }^{274}$ Press Statement, U.N. High Comm'r For Hum. Rts., Joint Statement by UN Human Rights Experts on the Occasion of the High-Level Meeting on Ending AIDS by 2030, 7 https://www.ohchr.org/EN/NewsEvents/Pages/DisplayNews.aspx?NewsID=20053\&LangID=E\%2 (last visited Nov. 21, 2018).

${ }^{275}$ Letter from the Office of the President of the General Assembly, to Permanent Mission of the Arab Republic of Egypt to the United Nations (Apr. 26, 2016) (on file with author).

${ }_{276}$ See Astor \& Lederer, supra note 268. UN officials also reported the EU and Canada wrote letters protesting the OIC request; see Muslim States Block 11 LGBT Groups, supra note 271.

277 Dainius Pūras (Special Rapporteur on the Right of Everyone to the Enjoyment of the Highest Attainable Standard of Physical and Mental Health), Report on his Visit to Malaysia (19 November-2 December 2014), Addendum, I 87, U.N. Doc. A/HRC/29/33/Add.1 (May 1, 2015) [hereinafter Report on his Visit to Malaysia]; see also Dainius Püras (Special Rapporteur on the Right of Everyone to the Enjoyment of the Highest Attainable Standard of Physical and Mental Health), Country Visit to Indonesia, 22 March to 3 April 2017, Preliminary Observations (Apr. 3, 2017),

http://www.ohchr.org/EN/NewsEvents/Pages/DisplayNews.aspx?NewsID=21472\&LangID=E ("discriminatory attitudes contribute to increased vulnerabilities to ill health, including HIV infection, and to increased stigma and harassment in healthcare settings while seeking treatment and services for sexual health, including refusal of admission or services").

278 Report on his Visit to Malaysia, supra note 277, 994. 
in "abusive forced treatment . . . and procedures to change the sexual orientation of people, so-called "corrective therapies." 279

Experience indicates that promulgating such policies breeds an environment of "discrimination, stigmatization and disrespect for human rights" that exacerbates the exposure of vulnerable groups to HIV/AIDS. ${ }^{280}$ Ultimately, such policies "only add to the continuation and further spread of HIV/AIDS." 281 The World Health Organization ("WHO"), the UN Development Program ("UNDP"), the Joint UN Program on HIV/AIDS ("UNAIDS"), and the UN treaty bodies have "widely acknowledged" the negative health fallout that flows from these types of discriminatory practices and associated laws criminalizing homosexuality. ${ }^{282}$ Beyond signaling a rejection of international norms, the troubling consequences that flow from the OIC's commitment to perpetuating such practices is confirmed by associated data. Only two of 57 OIC states achieved Millennium Development Goal 6 targets regarding efforts to combat HIV/AIDS, Malaria and other diseases. ${ }^{283}$ Coupled with this, OIC states also "lag behind other developing countries in the number of adult population who receive HIV/AIDS testing and counselling," providing such services at "less than half the average rate" of other reporting developing countries. ${ }^{284}$ Finally, OIC states continue to account for a disproportionately high percentage of global AIDS-related deaths. ${ }^{285}$

Though unsettling, one IPHRC Commissioner's blunt attitude may help shed some light on the rationale motivating OIC state practices and the organization's concerted push to exclude NGOs such as the Jamaica Forum of Lesbians from participating in the High Level Meeting. ${ }^{286}$ According to Commissioner Alaei, it has precious little to do with protection of the family: "Pervert practices such as LGBT"s can in no way be accepted under the rubric of freedom and the so called ownership of the [sic] one's body as a right. These

${ }^{279}$ See id. The IPHRC endorsed this discredited treatment in its 2017 report on SOGI. See infra Part III(C)(2).

280 See Report on his Visit to Malaysia, supra note 277, ๆ 95.

281 See id.

${ }^{282}$ Discrimination and Violence Against Individuals Based on Their Sexual Orientation and Gender Identity, supra note 181, ๆ 51.

${ }^{283}$ OIC Strategic Health Programme of Action 2014-2023, STAT., Econ. \& Soc. RES. \& TRAINING CTR. ISLAMIC COUNTRIES 11 (2014), http://www.sesric.org/files/article/480.pdf.

${ }^{284} \mathrm{Id}$. at 31.

${ }^{285}$ See id. at 30-31 (explaining that "people receiving antiretroviral therapy (ART) within the total estimated number of people living with HIV/AIDS in 41 reporting OIC countries was on average only $14 \%$ - as compared to $24 \%$ in other 68 developing countries and $59 \%$ in 13 developed countries with reported data.").

${ }^{286}$ The Jamaica Forum of Lesbians was one of the eleven NGOs targeted by the OIC for exclusion from the High Level Meeting on Ending AIDS. Permanent Mission of the Arab Republic of Egypt, Letter From a Group of 51 OIC States to UNGA President (Apr. 26, 2016) (on file with the author). 
devastative and abhorrent practices cannot be accepted as manifestation of a modern society." 287

Many OIC states reveal sentiments that in practice promise the same effect as Mr. Alaei's views, though they are couched in more diplomatic terms. For example, in setting out their reservations to the 2016 Political Declaration on HIV and AIDS-the consensus-based outcome document of the high-level meeting-OIC states opted to reject:

Recognition that "many national HIV prevention, testing and treatment programmes provide insufficient access to services for ... key populations that epidemiological evidence shows are globally at higher risk of HIV [including] men who have sex with men, who are 24 times more likely to acquire HIV [and] transgender people, who are 49 times more likely to be living with HIV";288

"The need to promote the development of and access to tailored comprehensive HIV prevention services for all . . . key populations"; 289 and

Recognition of vulnerable groups. ${ }^{290}$

The motivation for these sweeping reservations gravitated around a common relativistic rationale. For example, Djibouti emphasized the need of every country to implement the Declaration's commitments "in strict compliance with the different cultural, ethical and religious values that underpin each society"; ${ }^{291}$ Indonesia stressed that use of the term "key populations" would not limit its "authority to define key populations or populations at greater risk of HIV infection according to its national circumstances"; 292 and Egypt called attention to "controversial points that do not enjoy consensus among all States on account of social, cultural and religious diversity and different values across countries," 293 asserting further that use of the terms "populations at high-risk," "vulnerable populations," "key populations" and "populations that epidemiological evidence shows are at

\footnotetext{
${ }^{287}$ Alaei, supra note 255, at 5.

288 G.A. Res. 70/266, supra note 266, ๆ 42.

${ }^{289} \mathrm{Id}$. ๆ 62(e).

${ }^{290}$ See id. ๆๆ 62(g)-(h).

${ }^{291}$ U.N. GAOR, 70th Sess., 97th plen. mtg., at 14, U.N. Doc. A/70/PV.97 (June 8, 2016) (Among other OIC states, Sudan, Egypt, and Iran raised similar specific objections to 942 and 62(e)).

${ }^{292} I d$. at 16. (Indonesia further objected to omission of language in the declaration endorsing riskavoidance measures, "including abstinence and fidelity," which were, in its view, "the most effective measures for preventing the spread and bringing about the end of HIV... and also in line with our cultural, religious and moral values.”).

${ }^{293} I d$.
} 
higher risk of infection" was "not in line with [Egypt's] values and culture." 294 Libya expressed similar reservations "on all contentious formulations that embody the difficulties identified [by other OIC states] as these formulations run counter to Islamic culture and our national legislation." 295 Finally, Bangladesh regretted that the 2016 Political Declaration failed to carry over the recognition extended to "social, cultural, religious norms and values" in the 2011 declaration. 296

Along with these individual reservations, the Group of African States, which includes fifty percent of the OIC's members, reaffirmed state sovereignty and the need to implement commitments, "consistent with national law, national development priorities, full respect for the various religious and ethical values and cultural backgrounds of its people and in conformity with universally recognized human rights." 297 At the same time, the Group asserted that for the purposes of its member states, any undertakings owed to "key populations" would be interpreted to apply to "women and adolescent girls" only. ${ }^{298}$ Thus, it flatly rejected the SDG High Level Political Forum's findings acknowledging the need to extend access to comprehensive prevention services to specific key populations including sex workers, people who inject drugs, transgender people, and men who have sex with men. ${ }^{299}$

The OIC's emphasis on protecting religious and cultural beliefs over the promotion of SRH and equal and nondiscriminatory provision of services to vulnerable groups grounded in scientific evidence did not go without criticism. Perhaps most forcefully, the Netherlands, speaking on behalf of EU member states called on all governments:

to place women above cultural belief, recognize their rights, deal with their disadvantaged positions, recognize the rights of lesbian, gay, bisexual and transgender people, allow sex education, give the poorest of the poor access to care and therapy, and do not give in to religious objections to condoms. The God we share celebrates life, and AIDS is death. "Leave no one behind"- that is what we all promised to do when we

\footnotetext{
${ }^{294} I d$. at 17 (Saudi Arabia, representing the six members of the Gulf Cooperation Council (all OIC states), reiterated Egypt's views).

${ }^{295} I d$. at 18. (noting that Yemen similarly concluded "the Declaration includes formulations that give rise to the reservations expressed by the representatives of Libya, the Sudan, Egypt and Saudi Arabia, given that they run counter to our national legislation. As a result, we ask that these reservations be placed on record.”).

${ }^{296}$ U.N. GAOR, 70th Sess., 101st plen. mtg., at 9, U.N. Doc. A/70/PV.101 (June 10, 2016).

${ }^{297}$ U.N. GAOR, 70th Sess., 98th plen. mtg., at 6, U.N. Doc. A/70/PV.98 (June 8, 2016).

${ }^{298} I d$.

${ }^{299}$ See 2017 HLPF Thematic Review of SDG3, supra note 253.
} 
pledged our support for the global goals last year. Let us practice what we preach. 300

\section{Rejection of SOGI Recognition: Extrajudicial Killings}

Like its rejection of universal and comprehensive HIV/AIDS education and services in the context of SRH, the OIC's denial of SOGI rights elsewhere comes with similarly life-threatening consequences that transcend clinical questions of equality and nondiscrimination. Human rights bodies have longrecognized the potential fallout associated with government authorization or toleration of unequal or discriminatory treatment. For example, the UN Committee Against Torture has observed that laws criminalizing consensual same-sex conduct "violate the rights to privacy and non-discrimination ... [but also] exacerbate the risk of other violations and impede the elimination of impunity in relation to torture and ill-treatment." ${ }^{01}$ The UN's Special Rapporteur on extrajudicial executions reached a similar conclusion nearly two decades earlier, in 1999:

criminalizing matters of sexual orientation increases the social stigmatization of members of sexual minorities, which in turn makes them more vulnerable to violence and human rights abuses, including violations of the right to life. Because of this stigmatization, violent acts directed against persons belonging to sexual minorities are also more likely to be committed in a climate of impunity. ${ }^{302}$

This dramatic finding represented the Special Rapporteur's first attempt ${ }^{303}$ to raise the issue of SOGI discrimination in the context of the right to life and call attention to "numerous and continuing reports of persons having been killed or sentenced to death because of their sexual orientation." 304

${ }^{300}$ U.N. GAOR, 70th Sess., 99th plen. mtg., at 3-4 U.N. Doc. A/70/PV.99 (June 9, 2016). Not to be outdone, France expressed its "regret[ that the Political Declaration . . . was unable to fully take key populations into account. To believe that we could eradicate AIDS without specifically targeting men having sex with men, inmates, immigrants, drug-users is deceptive." Id. at 15.

${ }^{301}$ Comm. Against Torture, Ninth Annual Report of the Subcommittee on Prevention of Torture and Other Cruel, Inhuman or Degrading Treatment or Punishment, U.N. Doc. CAT/C/57/4 (Mar. 22, 2016). In a similar manner, the CESCR concluded that the initial action of denying the right to an abortion "often leads to maternal mortality and morbidity, which in turn constitutes a violation of the right to life or security, and in certain circumstances can amount to torture or cruel, inhuman or degrading treatment." Comment No. 22, supra note 234, \10.

302 Asma Jahangir (Special Rapporteur on Extrajudicial Executions), Civil and Political Rights, Including Questions of: Disappearances and Summary Executions, I| 77, U.N. Doc. E/CN.4/1999/39 (Jan. 6, 1999).

${ }^{303}$ Bacre Waly Ndiaye (Special Rapporteur), Question of the Violation of Human Rights and Fundamental Freedoms in Any Part of the World, With Particular Reference to Colonial and Other Defendant Countries and Territories, U.N. Doc. E/CN.4/1998/68 (Dec. 23, 1997). The Special Rapporteur's prior report from 1997 omitted consideration of SOGI. See id.

304 Ninth Annual Report of the Subcommittee on Prevention of Torture and Other Cruel, Inhuman or Degrading Treatment or Punishment, supra note 301, ๆ 76. 
Rather than take action on the finding, however, the ensuing UN Commission on Human Rights' (“UNCHR") resolution addressing extrajudicial executions opted to merely take note of the Special Rapporteur's report. ${ }^{305}$

This changed the following year. The Special Rapporteur's follow up report provided a similar if slightly expanded assessment of SOGI discrimination (doubling from two to four paragraphs) under the heading "Violations of the right to life of members of sexual minorities." 306 But in contrast to its 1999 response, the UNCHR's follow up resolution on extrajudicial, summary or arbitrary executions for the first time expressly "[n]ote[d] with concern the large number of cases in various parts of the world ... [where] persons [were] killed because of their sexual orientation." Faced with this finding, the UNCHR "call[ed] upon Governments concerned to investigate such killings promptly and thoroughly, to bring those responsible to justice and to ensure that such killings are neither condoned nor sanctioned by government officials or personnel." 307

Since the apparently uneventful milestone passage of Resolution 2000/31, however, the OIC has mounted an ongoing effort to strike any reference to sexual orientation from similar UN resolutions on extrajudicial, summary or arbitrary executions. In an effort to ensure renewal of the Special Rapporteur's mandate, negotiated changes ${ }^{308}$ to the final 2001 resolution on extrajudicial executions deleted the words "killings of persons because of sexual orientation." 309 The Commission restored the omitted wording in its 2002 resolution, but not without resorting to a contentious vote. ${ }^{310}$ Following the Swedish delegate's expression of regret that consensus language could not garner OIC approval of a resolution affirming the obligation of states to protect all citizens irrespective of sexual orientation, ${ }^{311}$ an OIC-initiated vote to again

\footnotetext{
${ }^{305}$ Comm’n on Human Rights Res. 1999/35, ๆ 8 (Mar. 22-Apr. 30, 1990).

${ }^{306}$ Asma Jahangir (Special Rapporteur on Extrajudicial Executions), Civil and Political Rights, Including Questions of: Disappearances and Summary Executions, ๆ 54 U.N. Doc. E/CN.4/2000/3 (Jan. 25, 2000).

[The report reiterated] "serious reports of persons having been subjected to death threats or extrajudicially killed because of their sexual orientation" and concluded that "continuing prejudice against members of sexual minorities and especially the criminalization of matters of sexual orientation...makes them more vulnerable to violence and human rights abuses, including death threats and violations of the right to life, which are often committed in a climate of impunity.

${ }^{307}$ Comm'n on Human Rights Res. 2000/31, ๆ 6 (Apr. 20, 2000).

308 See Comm'n on Human Rights Res. 2001/45 (Apr. 24, 2001).

${ }^{309}$ Summary Record of the 72d Meeting, Commission on Human Rights, 3d sess., 9 ๆ 69-74, U.N. Doc. E/CN.4/2001/SR.72 (Apr. 27, 2001).

310 See Comm'n on Human Rights, Res. 2002/36 (Apr. 20, 2002).

311 U.N. GAOR, 48th Sess., 50th mtg., ๆ 80, U.N. Doc. E/CN.4/2002/SR.50 (July 20, 2002).
} 
strike references to "sexual orientation" from the text failed to muster a majority. 312

OIC efforts to delete references to "sexual orientation" in the context of extrajudicial killings carried over from the UNCHR to the General Assembly. ${ }^{313}$ For example, in 2006, Azerbaijan on behalf of the OIC submitted a failed amendment to delete reference to sexual orientation from the General Assembly resolution on extrajudicial execution. ${ }^{314}$ In 2010 , however, the OIC witnessed a short-lived success. During a Social, Humanitarian and Cultural Affairs Committee (Third Committee) meeting over a draft resolution on extrajudicial execution, member states voted $79-70^{315}$ to pass an OICsponsored amendment to delete language alluding to sexual orientation. ${ }^{316} \mathrm{In}$ advance of the vote, the OIC argued that the "concept of sexual orientation had no basis in, and should not be linked to, existing international human rights." 317 The organization further warned that the "international community must avoid selectivity in the field of human rights, which would set a dangerous precedent and promote the interests of particular groups over others." 118

Deletion of the draft resolution's original wording triggered significant NGO and media attention. ${ }^{319}$ In turn, a concerted push in the General Assembly sought to amend the resolution once more to restore the specific reference to "sexual orientation." Again, the OIC opposed the effort, positing that sexual orientation amounted to an "undefined notion] [with] no legal foundation in any international human rights instrument." ${ }^{320}$ It also warned

312 Id. ๆๆ 84-90.

313 See U.N. GAOR, 57th Sess., 77th plen. mtg., at 21-22, U.N. Doc. A/57/PV.77 (Dec. 18, 2002); U.N. GAOR, 49th Sess., 59th mtg., U.N. Doc. A/C.3/57/SR.59 (Dec. 13, 2003); G.A. Res. 57/214, 6 (Feb. 25, 2003).

${ }^{314}$ Azerbaijan: Amendment to Draft Res. A/C.3/61/L.45/Rev.1, Third Comm. on Its Sixty-First Session, U.N. Doc. A/C.3/61/L.59 (Nov. 15, 2006); G.A. Res. 61/173, ๆ 5(b) (Mar. 1, 2007).

315 See Recorded Vote from the 46th Meeting, Third Comm., (Nov. 16, 2010). States opposed to the OIC's substitute language lamented the "unfriendly amendment" and the Third Committee's inability "to bring itself to condemn killings targeting individuals because of their sexual orientation.” U.N. GAOR, 65th Sess., 46th mtg., \ 52, U.N. Doc. A/C.3/65/SR.46 (Jan. 18, 2011).

${ }^{316}$ Mali and Morocco: Amendment to Draft Resolution A/C.3/65/L.29/Rev.1, Third Comm. on Its Sixty-Fifth Session, U.N. Doc. A/C.3/65/L.65 (Nov. 12, 2010) (on behalf of the members of the Group of Arab States and members of the Organization of the Islamic Conference).

317 U.N. GAOR, 65th Sess., supra note 315, ๆ 29.

${ }^{318} I d$.

319 See Jessica Stern, Civil Society Pressures Governments to Successfully Reverse Discriminatory Vote at UN, OUTRIGHT ACTION INT'L (Dec. 21, 2010), https://www.outrightinternational.org/content/civil-society-pressures-governments-successfullyreverse-discriminatory-vote-un; Louis Charbonneau, U.N. Panel Cuts Gay Reference from Violence Measure, REUTERS (Nov. 16, 2010), http://uk.reuters.com/article/us-un-gaysidUSTRE6AG0BB20101117.

${ }^{220}$ U.N. GAOR, 65th Sess., 71st plen. mtg. at 16, U.N. Doc. A/65/PV.71 (Dec. 21, 2010). 
that "focus on certain persons on the grounds of their sexual interests and behaviours" could only come at the expense of combatting the general scourge of intolerance and discrimination. ${ }^{321} \mathrm{In}$ addition, the OIC incoherently reasoned that individuals are only "made vulnerable due to the socio-economic setting in which they live," 322 thus obviating any possibility that cultural, religious, or political factors (among others) might bear equal responsibility for facilitating or condoning the types of discrimination and violence addressed in the resolution. Ultimately, the General Assembly adopted the revised resolution on extrajudicial executions, inclusive of the reference to sexual orientation, 109-41, with 35 abstentions. ${ }^{323}$

At the end of 2016, an OIC-sponsored amendment to the annual resolution on extrajudicial execution sought once again to delete a specific reference to vulnerable groups, including on the basis of SOGI. The amendment proposed to have the resolution apply more generally for "discriminatory reasons on any basis whatsoever." 324 The sense of déjà vu in the Third Committee must have been palpable when the Uzbek delegate, in presenting the OIC amendment for a vote, rehashed verbatim the Saudi delegate's 2014 view that the "OIC believed that people were not inherently vulnerable but some individuals were made vulnerable by their socioeconomic setting." 325 Since it would be impossible to list all vulnerable groups (again, despite specific Special Rapporteur findings to the contrary and the fact that framing the term "vulnerable" in this way would void it of any practical meaning), the Uzbek delegate posited (still using the previous Saudi script) that it would be "more prudent to alter the language" by deleting these specific references. ${ }^{326}$ Based on this reasoning, the OIC's representative urged Member States to support the amendment on the absurd grounds (again verbatim) that they "should refrain from attempting to give priority to the rights of certain individuals, as

${ }^{321} I d$.

${ }^{322} I d$. The Tajik delegate for the OIC concluded his statement on an ominous note:

[I]n the future, [the OIC] will carefully assess its position on specific issues based on the flexibility shown and political stand taken by partners on issues of importance to the OIC. There will be no more unilateral concessions, as clapping requires the use of both hands. We hope that this message will be taken positively and lead to genuine and constructive engagement that results in consensus-building on all issues of importance.

$I d$.

${ }^{323}$ Id. at 19; see G.A. Res. 65/208 (Dec. 21, 2010).

324 Uzbekistan: Amendment to Draft Resolution A/C.3/71/L.38, Third Comm., U.N. Doc. A/C.3/71/L.53 (Nov. 11, 2016) (mirroring an identical amendment proffered by Egypt on behalf of the OIC in 2014); Egypt: Amendment to Draft Resolution A/C.3/69/L.47/Rev.1, Third Comm., U.N. Doc. A/C.3/69/L.64 (Nov. 17, 2014).

${ }^{325}$ Compare U.N. GAOR, 71st Sess., 52d mtg., \ 48, U.N. Doc. A/C.3/71/SR.52 (Jan. 12, 2017), with U.N. GAOR, 69th Sess., supra note 325.

${ }^{326}$ U.N. GAOR, 71st Sess., supra note 325 (parroting Saudi Arabia's remarks from the 2014 debate); U.N. GAOR, 69th Sess., supra note 325. 
doing so could result in positive discrimination at the expense of the rights of others, in contravention of the principles of non-discrimination and equality." 327

Reviewing the summary record, one wonders whether the Uzbek delegate blushed for cribbing his colleague's two-year-old oral statement, for mustering the temerity to urge other member states to support the OIC's dodgy amendment, or both. But setting aside the intriguing-though admittedly tangential question - of personal dignity, the substance of the OIC's proffered justification rightfully demands unpacking for its cynical attempt to turn human rights principles on their head.

On a foundational level, the OIC's justification ignores several essential characteristics associated with equality and non-discrimination norms identified by the UN Human Rights Committee. First, "enjoyment of rights and freedoms on an equal footing" does not necessarily entail "identical treatment in every instance." ${ }^{28}$ Second, positive discrimination or "affirmative action" sometimes may be necessary and permissible "to diminish or eliminate conditions which cause or help to perpetuate discrimination." ${ }_{229}$ Finally, not all differential treatment will constitute discrimination "if the criteria for such differentiation are reasonable and objective" and the aim supports a legitimate purpose. ${ }^{330}$ More practically, actual implementation of the OIC's faulty approach would suggest state inaction is somehow an appropriate response to confronting specific human rights violations impacting recognized vulnerable individuals. Denying protection to these individuals because others not identified as vulnerable might suffer discrimination distorts the intent of nondiscrimination and equality norms and is antithetical to the purpose of the international human rights regime.

Ultimately, the Third Committee rejected the OIC-proposed amendment eighty-four votes to sixty, with twenty-seven abstentions. ${ }^{331}$ The final General

327 U.N. GAOR, 71st Sess., supra note 325 (parroting Saudi Arabia's remarks from the 2014 debate); U.N. GAOR, 69th Sess., supra note 325 . This line of reasoning is directly at odds with the OIC's parallel attempt to secure a UN resolution focused exclusively on "defamation of Islam," inasmuch as that effort would similarly prioritize a certain religion and result in "positive discrimination at the expense of the rights of others." See generally Robert C. Blitt, Should New Bills of Rights Address Emerging International Human Rights Norms? The Challenge of "Defamation of Religion”, 9 Nw. J. INT'L HUM. RTS. 1 (2010).

328 Human Rights Comm., General Comment No. 18: Non-discrimination, \& 8, U.N. Doc. HRI/GEN/1/Rev.9 (Vol. I) (Nov. 10, 1989)

${ }^{329} I d$. | 10. (requiring "preferential treatment" in order "to correct discrimination in fact, it is a case of legitimate differentiation under the Covenant").

${ }^{330} I d$. ๆ 13.

${ }^{331}$ U.N. GAOR, 71st Sess., supra note 325, ๆ $956-57$ (showing that forty-two OIC states voted in favor, two against (Albania and Turkey), and five abstained and the voting pattern closely mirrored the Third Committee's rejection of the OIC's identical amendment in 2014 (eighty-two in favor, fifty-three opposed, with twenty-four abstentions)); U.N. GAOR, 69th Sess., supra note 325, II 30-31. Likewise, in 2014, Albania and Turkey were the only OIC states to vote against the OIC-sponsored amendment. Id. ๆ 30. 
Assembly resolution, (adopted by 125 votes to 2 , with 56 abstentions, with OIC states accounting for over $60 \%$ of abstaining states), ${ }^{332}$ urged all states

[t]o ensure the effective protection of the right to life of all persons, to conduct, when required by obligations under international law, prompt, exhaustive and impartial investigations into all killings, including . . . of persons belonging to national or ethnic, religious and linguistic minorities or because of their sexual orientation or gender identity ... and killings committed for discriminatory reasons on any basis, to bring those responsible to justice before a competent, independent and impartial judiciary . . . and to ensure that such killings ... are neither condoned nor sanctioned by State officials or personnel. ${ }^{333}$

The OIC's explanation before voting on the final 2016 extrajudicial executions resolution appeared to move beyond its previous poorly designed and executed verbal gymnastics. Rather than claim SOGI recognition would amount to unlawful "positive discrimination," the organization fell back to its first principles. In doing so, it offered a far more sweeping claim that SOGI recognition fell altogether outside the scope of international human rights:

[The] OIC strongly rejected any attempt to undermine the international human rights system by imposing concepts pertaining to social issues that were not part of the internationally agreed human rights legal framework. Such attempts disregarded the universality of human rights and disrespected cultural and social specificities, norms and diversities that existed between societies and communities. The group was alarmed, in particular, at systematic efforts to reinterpret the Universal Declaration of Human Rights and other international treaties in the light of notions never articulated or agreed by the general membership of the United Nations and to impose those notions through United Nations resolutions. ${ }^{334}$

\footnotetext{
332 The 2017 vote mirrors the 2014 UNGA vote to pass the resolution on extrajudicial executions122-0 with 66 abstentions (with OIC states accounting for over 60 percent of abstaining states). U.N. GAOR, 69th Sess.,73d plen. mtg. at 16-17, U.N. Doc. A/69/PV.73 (Dec. 18, 2014); Id. at 6 (demonstrating that the voting outcome arguably diminishes the claim that no international consensus exists for recognizing SOGI-based protection).

${ }^{333}$ G.A. Res. 71/198, - 6(b) (Jan. 25, 2017) (showing that the language is identical to the prior 2014 UNGA resolution on extrajudicial executions); G.A. Res. 69/182, ๆ 6(b) (Jan. 30, 2015).

${ }_{334}$ U.N. GAOR, 71st Sess., supra note 325, - 59. The Egyptian delegate hinted at these reasons in 2014, expressing alarm over the "systematic attempts to include in the resolution notions that had not been agreed upon by the general membership of the United Nations." During the same debate, the representative of Iran similarly rejected reference to "notions that did not have internationally agreed definitions, including 'sexual orientation' and 'gender identity." U.N. GAOR, 69th Sess., supra note 325 , ๆ $37,42$.
} 
Taken at face value, this straightforward position drains any meaningful substance from simultaneous OIC assurances that its "member States deplore[ all forms of stereotyping, exclusion, stigmatization, prejudice, intolerance, discrimination and violence directed against peoples, communities and individuals, on any grounds." 335 It also affirms the conclusion that OIC opposition to SOGI recognition cuts across different human rights issues that pre-date and are unrelated to protection of the family. Moreover, it confirms that the organization's opposition is rooted in something deeper, and is more sweeping than narrow, issue-specific quibbles such as who may or may not be "vulnerable," what constitutes unlawful "positive" discrimination in the context of extrajudicial executions, or even protection of the family.

At its core therefore, the OIC's justification for opposing SOGI rights appears to rest on two faulty pillars. The first is a facile understanding of foundational international human rights law ("IHRL") norms that posits in the absence of express universal recognition of SOGI as a vulnerable class, such recognition must necessarily be denied. The second is a steadfast prioritization of an indeterminate religious dogma over individual rights. This faulty prioritization is embodied in the Cairo Declaration on Human Rights in Islam ("CDHRI") and the Bangkok Declaration, and is intended to short-circuit the clear directive contained in the Vienna Declaration and Program of Action ("VDPA") that states owe a duty to promote and protect all human rights and fundamental freedoms, regardless of localized particularities. Stated differently, from the OIC's perspective, universal human rights norms cannot protect a class without express reference to a defining characteristic, such as race or religion. Alternatively, even if such protection were to apply under international law, relativism (manifested, for example, in a particularized definition of "family" or a claim of disrespect for cultural and social specificities) operates to shield states from any obligation that might attach.

Invoking either of these justifications serves the OIC's underlying objective, namely securing its religious beliefs and cultural practices from human rights scrutiny. However, a clear distinction exists between them. Arguably, a relativist approach might acknowledge the substance of a human right but seek dispensation from its application based on a specific religious, cultural or other localized practice that conflicts with the right. In contrast, the OIC's revisionist approach-namely restricting equality and nondiscrimination protections only to those groups and characteristics expressly referenced under the UDHR - is premised on rewriting the substance of universal human rights. This approach denies, among other things, ongoing developments at the UN, longstanding and authoritative interpretations of the foundational norms governing the international human rights system, and indeed even the UDHR grundnorm that "[a]ll human beings are born free and equal in dignity and rights." ${ }^{336}$

\footnotetext{
335 U.N. GAOR, 71st Sess., supra note 325, ๆ 48.

336 UDHR, supra note 2, art. 1.
} 
The pervasiveness of the OIC's opposition to SOGI and the associated shortcomings of its reliance on relativist and revisionist justifications are readily confirmed by reviewing the organization's efforts surrounding the milestone 2011 UNHRC SOGI resolution and its aftereffects. But before turning to this assessment, two additional manifestations of opposition to SOGI recognition merit consideration. These brief examples elaborate the existing international guidance on SOGI rights. Furthermore, they confirm that the OIC's multiple justifications for rejecting SOGI are poor cover for a hardened campaign committed to denying equality and perpetuating discrimination against individuals who fall outside of the organization's selfproclaimed religious strictures, even if it comes at the cost of human life.

\section{Rejection of SOGI Recognition: Torture and Inhuman or Degrading} Treatment

The UN Special Rapporteur on torture's 2016 report recognized that the "purpose and intent elements of the definition of torture ... are always fulfilled if an act is gender-specific or perpetrated against persons on the basis of their sex, gender identity, real or perceived sexual orientation or non-adherence to social norms around gender and sexuality." 337 Further, the report reiterated that "[a] clear link exists between the criminalization of [LGBT] persons and homophobic and transphobic hate crimes, police abuse, community and family violence and stigmatization." 338 Based on these findings, the rapporteur concluded that "[s] tates have a heightened obligation to prevent and combat gender-based violence and discrimination against women, girls, and [LGBT] and intersex persons that amount to torture and ill-treatment, committed in a variety of contexts by both State and [non-state] actors." "339 Additionally, states "must decriminalize same-sex relationships between consenting adults and repeal all laws that criminalize persons on the basis of their actual or perceived sexual orientation or gender identity or expression." ${ }^{340}$ Faced with these decisive conclusions, the OIC offered the vague response that it had reservations "over the introduction of controversial issues in the report that are not agreed in any international, UN Human Rights instruments." ${ }^{41}$

Supporting the Special Rapporteur's findings, the 2016 annual report of the Subcommittee on Prevention of Torture reiterated the obligation of states to extend basic human rights protections to all individuals, including nondiscrimination based on SOGI. According to the Subcommittee, "[t]here is abundant evidence to conclude that torture and ill-treatment of [LGBT] and

${ }^{337}$ U.N. Human Rights Council, Report of the Special Rapporteur on Torture and Other Cruel, Inhuman or Degrading Treatment or Punishment, ๆ 8, U.N. Doc. A/HRC/31/57 (Jan. 5, 2016).

${ }^{338} I d$. 15.

${ }^{339} I d$. 68.

${ }^{340} I d$. ๆ 69.

${ }^{341}$ Press Statement, Mariam Saeed, Comments on Behalf of OIC during the Interactive Dialogue with the Special Rapporteur on Sale of Children and Special Rapporteur on Torture (Mar. 8, 2016). 
intersex persons are endemic concerns . . . ." 342 Accordingly, under the Convention Against Torture and Other Cruel, Inhuman or Degrading Treatment or Punishment ("CAT"), states have an obligation to "design and implement legislative, administrative and judicial measures to prevent" such treatment. ${ }^{343}$ This includes a duty to consult LGBT and intersex persons "in the design, implementation and evaluation of measures adopted to prevent torture and ill-treatment against them." 344

To understand how at least one OIC member state interprets its nondiscrimination obligation in the context of torture and inhuman treatment, a recent example from Egypt is instructive. In 2015, multiple UNHRC mandate holders communicated an urgent appeal to the government of Egypt concerning its alleged arbitrary arrest, detention, torture, and public stigmatization of twenty-six men arrested on charges related to their alleged sexual orientation. Among other things, the mandate holders requested Egypt provide information related to:

"allegations indicating that the 26 men were subjected to forensic anal examinations upon the request of the prosecutor, and explain how this complies with Egypt's obligations under international human rights law and standards;" and

"the measures taken by the authorities to protect lesbian, gay, bisexual and transgender persons in Egypt from arbitrary arrest and detention, violence and discrimination on the grounds of their sexual orientation and/or gender identity." 345

The Egyptian government's one-page response to the detailed allegations set out in the urgent appeal stated that the accused had been acquitted and offered a blanket denial of any human rights violations: "There is no truth in the claim that before or during the trial the accused suffered torture or illtreatment. They were arrested and detained in accordance with the procedures laid down in the Code of Criminal Procedure, which are all compatible with relevant international human rights obligations and standards." ${ }^{446}$ Relaying this exchange to the Human Rights Council, the Special Rapporteur on torture took note of Egypt's failure to provide details as to how its investigation was conducted or to "address the larger question of whether persons in Egypt are

${ }^{342}$ Ninth Annual Report of the Subcommittee on Prevention of Torture and Other Cruel, Inhuman or Degrading Treatment or Punishment, supra note 301, ๆ 49.

${ }^{343} I d$ ๆ 50.

${ }^{344} I d$. 171 . This approach embodies the GIPA principle discussed above at supra note 273.

${ }^{345}$ Mandates of the Working Group on Arbitrary Detention: the Special Rapporteur on the Right of Everyone to the Enjoyment of the Highest Attainable Standard of Physical and Mental Health; the Special Rapporteur on the Independence of Judges and Lawyers; and the Special Rapporteur on Torture and Other Cruel, Inhuman or Degrading Treatment or Punishment, UA EGY 1/2015, at 5-6 (2015) [hereinafter Mandates of the Working Group].

${ }^{346}$ Press Statement, Reply of the Egyptian Government to the Allegations Contained in the Urgent Appeal, ๆ 6, UA EGY 1/2015 (Feb. 20, 2015). 
treated in [a] humiliating manner when detained and investigated about their real or alleged homosexuality. ..." 347 In this context, the rapporteur reminded the Egyptian government of the absolute and non-derogable prohibition of torture and other ill-treatment codified under CAT art. 1. Lacking specific information refuting the allegations, the rapporteur concluded that the government had violated its CAT obligations "by failing to protect the physical and psychological integrity of the ... men arrested and tried ... [for] their alleged sexual orientation.” 348

\section{Rejection of SOGI Recognition: Freedom of Assembly}

The UDHR provides that "everyone has the right to freedom of peaceful assembly and association." 349 The ICCPR further requires that state parties secure these rights "without distinction of any kind, such as race, colour, sex, language, religion, political or other opinion, national or social origin, property, birth or other status." 350 When the UNHRC created the mandate for a Special Rapporteur on the rights to freedom of peaceful assembly and of association, it reaffirmed that "everyone has the rights to freedom of peaceful assembly and of association." 351

The Special Rapporteur's first thematic report, issued in 2012, recalled that the right to free assembly requires respect for ICCPR art. $26,{ }^{352}$ which guarantees "to all persons equal and effective protection against discrimination on any ground ...." 353 As such, the right to free assembly applies "inter alia to ... persons belonging to minority groups or other groups at risk, including those victims of discrimination because of their sexual orientation and gender identity ...." "354 Other than invoking permissible limitations authorized under the framework of the ICCPR, the OIC appeared to receive the 2012 report with little objection over the need to apply nondiscrimination and equality principles in the context of SOGI. ${ }^{355}$

\footnotetext{
347 Juan E. Méndez, Report of the Special Rapporteur on Torture and Other Cruel, Inhuman or Degrading Treatment or Punishment, $\mid$ 118, U.N. Doc. A/HRC/31/57/Add.1 (Feb. 24, 2016).

${ }^{348}$ Id. ๆ 120.

${ }^{349}$ UDHR, supra note 2, art. 20.

${ }^{350}$ ICCPR, supra note 28, art. 2; see also id. arts. 21-22.

${ }^{351}$ Human Rights Council Res. 15/21 (Oct. 6, 2010).

352 Maina Kiai, Report of the Special Rapporteur on the Rights to Freedom of Peaceful Assembly and of Association, I 13, U.N. Doc. A/HRC/20/27 (May 21, 2012).

${ }^{353}$ ICCPR, supra note 28, art. 26.

${ }^{354}$ Kiai, supra note 352 , 13.

${ }^{355}$ Press Statement, U.N. Human Rights Council, Draft Statement by Pakistan on Behalf of the OIC Member States During and ID with a) Special Rapporteur on the Promotion and Protection of Human Rights While Countering Terrorism and b) Special Rapporteur on the Freedom of Peace Assembly and Association (June 20, 2012).
} 
The OIC's muted response, however, changed in 2014 with release of the rapporteur's second report. This second report focused on threats to the rights to freedom of peaceful assembly and of association for groups most at risk. Specifically, it sought to address "the challenges facing" groups that "are often relegated to the margins of society, both in their daily lives and in the exercise of their rights to freedom of peaceful assembly and of association." 356 The Special Rapporteur expressly included LGBTI people as one of these marginalized groups and proceeded to explore how discrimination and unequal treatment impacted their rights to free assembly and association. ${ }^{357}$ During the ensuing interactive debate at the UNHRC, the OIC again reaffirmed the limitations built into ICCPR art. 21. But this time, its representative went on to express specific disappointment with the rapporteur's "reference to controversial notions which are not universally agreed rights such as LGBTI in the context of marginalized groups." ${ }^{358}$ The OIC's representative further asserted "[t]here is no such specific classification of rights in international human rights law or UN Charter and we should not create new category of rights." ${ }^{559} \mathrm{He}$ then injected a curious addition:

In compliance with international human rights law including ICERD [the International Convention on the Elimination of All Forms of Racial Discrimination], the OIC considers the promotion and protection of human rights and fundamental freedoms including the right to peaceful assembly and association of all peoples without any discrimination on the basis of gender, race, religion, colour or socio-economic status. ${ }^{360}$

The OIC's decision to specifically namecheck the ICERD in the context of a discussion on free assembly rights is self-serving and misleading. The UNHRC derived the Special Rapporteur's mandate first and foremost from the Universal Declaration of Human Rights (“UDHR”), International Covenant on Civil and Political Rights ("ICCPR"), and ICESCR, as well as "other relevant human rights instruments." 361 It did this for the simple reason that these primary treaties establish the fundamental right to assembly in its most wideranging context. Singling out the ICERD-with its targeted objective of

\footnotetext{
${ }^{356}$ Maina Kiai, Report of the Special Rapporteur on the Rights to Freedom of Peaceful Assembly and of Association, ๆ 8, U.N. Doc. A/HRC/26/29 (Apr. 14, 2014).

${ }^{357} \mathrm{Id}$. ๆ $27-31$.

358 Press Statement, U.N. Human Rights Council, Statement by Pakistan on Behalf of the OIC in the Interactive Dialogue with the Special Rapporteur on Freedom of Expression and the Special Rapporteur on Peaceful Assembly and Association, If 10 (June 10, 2014).

${ }^{359} I d$.

${ }^{360} I d$. ๆ 9

${ }^{361}$ Human Rights Council Res. 24/5 (Oct. 8, 2013).
} 
"eliminat[ing] racial discrimination in all its forms" 362 -as the basis for interpreting the right to free assembly diminishes the right's broad applicability and relevance beyond the confines of racial discrimination.

For example, unlike the ICCPR's more open-ended framing of nondiscrimination, the specialized nature of the ICERD necessitated a more focused and targeted list of protected classes. Accordingly, the ICERD narrowly limited its definition of "racial discrimination" to "any distinction, exclusion, restriction or preference based on race, colour, descent, or national or ethnic origin . . .." 363 As a consequence of this specificity, ICERD remained silent with respect to other recognized statuses including religion, disability, age, or sexual orientation. This specificity also explains why the ICERD's only reference to free assembly does not establish the general obligation of states to respect the right, but rather merely reiterates that it should be guaranteed to everyone "without distinction as to race, colour, or national or ethnic origin . . . ." ${ }^{364}$ Approaching the right to assembly in the OIC's narrow manner insinuates that states can achieve compliance with international nondiscrimination norms on an à la carte basis, whereby they pick and choose which groups or statuses merit protection. But based on the UDHR, ICCPR, and related international norms and developments ${ }^{365}$ this is plainly not the case.

Conflict over inclusion of SOGI recognition in the context of freedom of assembly has not abated. A joint UN Special Rapporteur report on the proper management of public assemblies released in 2016 significantly scaled back content relating to at risk groups. Nevertheless, the rapporteurs still reiterated the need "to ensure equal and effective protection of the rights of groups or individuals who have historically experienced discrimination [including] individuals who have been discriminated against on the basis of their sexual orientation or gender identity." 366 The rapporteurs further concluded that "[t]his duty may require that authorities take additional measures to protect and facilitate the exercise of the right to freedom of assembly by such groups." 367

The joint report did not prompt a formal OIC response. However, during a related interactive dialogue, at least one OIC state charged that the single

\footnotetext{
362 International Convention on the Elimination of All Forms of Racial Discrimination, Mar. 7, 1966, 660 U.N.T.S. 195, 5 I.L.M. 352 [hereinafter ICERD].

${ }^{363} I d$. art. 1(1).

${ }^{364} I d$. art. 5.

365 The Special Rapporteur outlines some of the relevant law in his report. Kiai, supra note 356, ๆๆ 16-20.

${ }^{366}$ U.N. Human Rights Council, Joint Report of the Special Rapporteur on the Rights to Freedom of Peaceful Assembly and of Association and the Special Rapporteur on Extrajudicial, Summary or Arbitrary Executions on the Proper Management of Assemblies, ๆ 16, U.N. Doc. A/HRC/31/66 (Feb. 4, 2016).

${ }^{367} I d$.
} 
reference (in an eleven-page document) to what he termed "the non-universally recognized controversial issue of LGBTs...under the pretext of right to peaceful assembly" had the effect of "undermin[ing] the credibility and practical recommendations of the report as a whole." 368 In response, the rapporteur on freedom of assembly stated: "There had to be clarity that the people who needed the right to demonstrate the most were the people who were the most marginalized .... Whether countries agreed with [LGBT] rights or not, that community needed to be protected like any other community. 'A right is something you have because you are' . . if the State had to authorise rights, they turned into privileges." 369

\section{Epicenter of the Clash: Formal UN Human Rights Council Recognition of Sexual Orientation and Gender Identity}

\section{UNHRC Resolution 17/19 on SOGI (2011)}

The above sections have provided a snapshot of OIC opposition to even tangential recognition of SOGI-based human rights protections. Yet the UNHRC's decision to begin adopting standalone resolutions dedicated to SOGI has triggered the OIC's most vociferous opposition to SOGI to date. The maelstrom surrounding these resolutions serves to pull together the OIC's various justifications proffered over the years to suppress the formal entrenchment of human rights protections for the LGBTI community.

In June 2011, the UNHRC voted to adopt an historic resolution explicitly addressing sexual orientation and gender identity. The first of its kind, Resolution 17/19 expressed "grave concern at acts of violence and discrimination ... committed against individuals because of their sexual orientation and gender identity." ${ }^{770}$ It also requested a UN Office of the High Commissioner for Human Rights ("OHCHR") report on the issue, as well as a panel discussion to be held at the UNHRC's 19th session. ${ }^{371}$ Despite its mild procedural content, the resolution's unprecedented subject matter sparked determined opposition and betrayed the gravity of SOGI as a human rights fault line for the OIC. Of the nineteen states voting against the UNHRC resolution, fifteen were OIC members. ${ }^{372}$

The subsequent $\mathrm{OHCHR}$ report on "discriminatory laws and practices and acts of violence against individuals based on their sexual orientation and

\footnotetext{
368 Press Statement, Islamic Republic of Iran on Clustered ID with SR on Peaceful Assembly and SR on Summary Executions, 31st Session of Human Rights Council (Mar. 9, 2016).

${ }^{369}$ U.N. Human Rights Council, Human Rights Council Holds Interactive Dialogue on Peaceful Assembly association (Mar. https://www.ohchr.org/EN/HRBodies/HRC/Pages/NewsDetail.aspx?NewsID=23232\&LangID=E.

${ }^{370}$ Human Rights Council Res. 17/19 (July 14, 2011).

${ }^{371} I d$.

${ }^{372}$ Id. The other states voting against Resolution 17/19 were: Angola, Ghana, Moldova and Russia. One OIC state, Burkina Faso, abstained.
} 
gender identity," released in late 2011, began by observing that throughout the world:

people experience violence and discrimination because of their sexual orientation or gender identity. In many cases, even the perception of homosexuality or transgender identity puts people at risk. Violations include-but are not limited tokillings, rape and physical attacks, torture, arbitrary detention, the denial of rights to assembly, expression and information, and discrimination in employment, health and education. ${ }^{373}$

The report offered a review of applicable international standards and obligations relating to universality, equality and non-discrimination. Using the UDHR's article 1 guarantee that "all human beings are born free and equal in dignity and rights" 374 as a departure point, the OHCHR observed that "[a]ll people, including lesbian, gay, bisexual and transgender (LGBT) persons, are entitled to enjoy the protections provided for by international human rights law, including in respect of rights to life, security of person and privacy, the right to be free from torture, arbitrary arrest and detention, the right to be free from discrimination and the right to freedom of expression, association and peaceful assembly." 375 Further, based on legal developments within the UN treaty bodies, the report confirmed "that States have an obligation to protect everyone from discrimination on grounds of sexual orientation or gender identity. The fact that someone is lesbian, gay, bisexual or transgender does not limit their entitlement to enjoy the full range of human rights." ${ }^{376}$ In light of these findings, the report recommended that states:

Enact comprehensive anti-discrimination legislation that includes discrimination on grounds of sexual orientation and gender identity among prohibited grounds and recognizes intersecting forms of discrimination; [and] ensure that combating discrimination on grounds of sexual orientation and gender identity is included in the mandates of national human rights institutions. ${ }^{377}$

The intervening year between passage of Resolution 17/19 and the convening of the requested panel discussion on SOGI did little to dissipate the tension. An official UN summary of the meeting notes that opponents "voiced their opposition on cultural or religious grounds, or argued that sexual

\footnotetext{
${ }^{373}$ Discriminatory Laws and Practices and Acts of Violence Against Individuals Based on their Sexual Orientation and Gender Identity, supra note 215, ๆ 1.

374 UDHR, supra note 2, art. 1.

375 Discriminatory Laws and Practices and Acts of Violence Against Individuals Based on their Sexual Orientation and Gender Identity, supra note 215, ๆ 5.

${ }^{376} I d$. ๆ 16.

${ }^{377} \mathrm{Id}$. ๆ $84(\mathrm{e})$.
} 
orientation and gender identity were new concepts that lay outside of the framework of international human rights law." 378 Further, a "number of States" opted to express their opposition to any discussion of SOGI by staging a walkout from Room XX of the Palais des Nations at the beginning of the meeting. ${ }^{379}$ Perhaps more revealing of the depth of this friction, certain unnamed meeting participants gave ominous notice that any effort to draft "new documents or agreements that focus specifically on the rights of LGBT persons ... could lead to a splintering of human rights into groups and subgroups." 380

Although the UN's official summary did not attribute actions or comments to specific states, media outlets widely reported that primarily OIC members participated in the walk-out. ${ }^{381}$ The move should not have come as a surprise. The OIC had made its position plain in advance, in a letter intended "to place on record" its opposition and to reject a priori any "considerations and recommendations" that might ensue from the discussion. ${ }^{382}$ Writing to the UNHRC president and High Commissioner for Human Rights, the OIC explained that its member states were "deeply concerned by the introduction . . of controversial notions like 'sexual orientation and gender identity," and "seriously concerned at the attempt to introduce... concepts that have no legal foundation in any international human rights instrument." 383 From the OIC's perspective, any UN recognition of "controversial 'new notions' or 'new standards" affording human rights protections on the basis of "abnormal sexual behaviour" would amount to a misinterpretation of the UDHR and other

${ }^{378}$ U.N. Human Rights Council Panel on Ending Violence and Discrimination Against Individuals Based on Their Sexual Orientation and Gender Identity: Summary of Discussion, UnITED NATIONS Hum. RTS. OFF. High COMMISSIONER (Mar. 7, 2012), http://www.ohchr.org/Documents/Issues/Discrimination/LGBT/SummaryHRC19Panel.pdf. A notably junior member of Pakistan's delegation delivered the remarks on behalf of the OIC during the panel discussion. Panel Discussion Sexual Orientation and Gender Identity, 22nd Meeting, U.N. WEB TV (Mar. 7, 2012), http://webtv.un.org/search/panel-discussion-sexual-orientation-andgender-identity-22nd-

meeting/5294863512001/?term=sexual\%20orientation\&lan=English\&sort=date\&page=2

[hereinafter SOGI Panel] (statement begins at approximately 00:53:10).

379 SOGI Panel, supra note 378. (The U.N. webcast of the panel discussion captures the walkout at approximately at 0:00:45-0:01:30).

${ }^{380} I d$. 22.

381 See Historic UN Session on Gay Rights Marked by Arab Walkout, RADIOFREEEURope RADIO LIBERTY, Mar. 7, 2012, http://www.rferl.org/content/arab_states_leave_un_gayrights_debate/24508579.html (last visited Nov. 21, 2018); Robert Evans, Islamic states, Africans Walk Out on UN Gay Panel, REUTERS (Mar. 8, 2012), http://www.reuters.com/article/ozatp-ungays-idAFJOE82702T20120308.

382 Letter to H.E. Ms. Laura Dupuy Lasserre, President of the Human Rights Council, to Zamir Akram (Feb. 14, 2012) [hereinafter Letter from OIC Group].

${ }^{383} I d$. The letter reiterates arguments previously delivered in the UNHRC at the time of the vote on Resolution 17/19. See Explanation of Vote by Pakistan, on Behalf of the OIC Member States, on Resolution Entitled "Human Rights, Sexual Orientation and Gender Identity," During the 17th Session of [sic] Human Rights Council, Geneva, 16/17 June 2011. 
international treaties. Such a move would, according to the letter, "undermine not only the intent of the drafters and signatories to these human rights instruments, but also seriously jeopardize the entire international human rights framework." 384

The OIC's revisionist justifications for denying SOGI recognition previously noted above-namely, that protection under IHRL requires express recognition or that any evolving interpretation is necessarily a misinterpretation-is flawed for several reasons. First, it has been longstanding practice among all key international human rights instruments to "include lists of prohibited grounds of discrimination in their nondiscrimination guarantees ... [that] all conclude with the words 'other status." 385 This purposeful phrasing demonstrates "that the lists were intended to be open-ended and illustrative," 386 rather than confined and impractical. More generally to this point, the law of treaties supports the view that where "a treaty is open to two interpretations one of which does and the other does not enable the treaty to have appropriate effects, good faith and the objects and purposes of the treaty demand that the former interpretation should be adopted." 387

The approach taken by the UN Committee on Economic, Social and Cultural Rights ("CESCR") in the context of disability rights is illustrative. Although the CESCR acknowledged the absence of an internationally accepted definition of the term "disability" as well as the absence of specific reference to persons with disabilities under the ICESCR, ${ }^{388}$ it nevertheless concluded that "persons with disabilities are clearly entitled to the full range of rights recognized" under the treaty. This conclusion flowed from the fact that disability corresponded to "other status" and the drafters' intent was to have the treaty "apply fully to all members of society." 389

${ }^{384}$ Letter from OIC Group, supra note 382.

385 U.N. High Commissioner for Human Rights, Born Free and Equal: Sexual Orientation and Gender Identity in International Human Rights Law, at 40 (2012).

${ }^{386} I d$.

387 Int'l Law Comm'n, Rep. of the Commission to the General Assembly in Its Eighteenth Session: Draft Articles on the Law of Treaties with Commentaries, 219 (1966). In the view of the International Law Commission, when properly limited and applied, this approach "does not call for an 'extensive' or 'liberal' interpretation in the sense of an interpretation going beyond what is expressed or necessarily to be implied in the terms of the treaty." Id.

${ }^{388}$ Comm. Econ. Soc. Cultural Rights, General Comment No. 5: Persons with Disabilities, ๆ ฯ 3, 5, U.N. Doc. E/1995/22, (Dec. 9, 1994).

${ }^{389} I d$. 15 . The Committee attributed the "absence of an explicit, disability related provision in the [ICCPR] . . to the lack of awareness of the importance of addressing this issue explicitly, rather than only by implication, at the time of the drafting of the Covenant." Id. - 6. The Committee has taken a similar approach concerning the omission of age as a prohibited ground: "this omission is probably best explained by the fact that, when these instruments were adopted, the problem of demographic ageing was not as evident or as pressing as it is now." Comm. Econ. Soc. Cultural Rights, General Comment No. 6: The Economic, Social and Cultural Rights of Older Persons, 9 11, U.N. Doc. E/1996/22 (Dec. 8, 1995). The Committee on the Rights of the Child has likewise 
Perhaps even more revealingly, the OIC has adopted the same approach for interpreting its own instruments. One of the organization's recent invocations of the CDHRI is particularly illuminating of this practice. During a discussion with the UN Special Rapporteur on the Rights of Persons with Disabilities in 2016, the OIC effectively "read in" recognition for disability rights under the CDHRI, based on the term "everyone." According to the OIC representative: "OIC Member States attach great importance to the participation of persons with disabilities in all aspects of life. We consider this not only an obligation but also a religious duty . . . article 23 (b) of the CDHRI insists that ' $[\mathrm{e}] \mathrm{veryone}$ shall have the right to participate, directly or indirectly in the public affairs of his country.' This includes individuals with disabilities." 390 To be clear, the CDHRI makes no reference to people with disabilities. But applying a purposive interpretation to "everyone" operates to secure rights protections for all members of society. Here, it is worth recalling that like the CESCR's inclusion of "other status", the CDHRI's provision on discrimination also opens the possibility of extending protection on the basis of "other considerations." 391

Second, the OIC's denial that IHRL tips towards inclusivity of SOGI protection is inconsistent with its own stance in the context of other international instruments and rights. For example, the OIC's own resolutions have endorsed the notion that international norm-setting is a "dynamic and evolving process." 392 Likewise, these resolutions have reaffirmed that international instruments maintain status as "living document[s] to be updated." 393 Perhaps most obviously though, the OIC continues to claim that religious sensitivities justify an international prohibition on defamation of religion and a coincident limitation on freedom of expression and freedom of religion or belief. This position surely constitutes a controversial 'new notion,' given strong international opposition and the reality that religions are not even contemplated as rights holders under IHRL. ${ }^{394}$ Yet, on this matter, the OIC has consistently claimed that the "new standard" of defamation of religion is a

interpreted "other status" to include HIV/AIDS status of children and parents, as well as mental health and sexual orientation. U.N. Comm. Rights Child, General Comment No. 3 (2003): HIV/AIDS and the Rights of the Child, If U.N. Doc. CRC/GC/2003/3, Mar. 17, 2003; U.N. Comm. Rights Child, General Comment No. 4 (2003): Adolescent Health and Development in the Context of the Convention on the Rights of the Child, I 2, U.N. Doc. CRC/GC/2003/4 (Jul. 1, 2003).

390 Tehmina Janjua, Interactive Dialogue with Special Rapporteur on the Rights of Persons with Disabilities, 31st Session of the Human Rights Council (Mar. 4, 2016). The invocation of the CDHRI here reinforces the point made previously in Parts II(B) II(C) concerning the Cairo Declaration's ongoing validity and its embodiment of norms the OIC aspires to transform into binding obligations.

391 CDHRI, supra note 16 , art. 1.

392 OIC Res. 1/41-LEG, supra note 101, ๆ 1.

393 OIC, Final Communique of the Annual Coordination Meeting of the Ministers of Foreign Affairs of the OIC Member States, ๆ 87, OIC Doc. OIC/ACM-2013/FC (Sept. 27, 2013) (referring to the U.N. Global Counter-Terrorism Strategy).

${ }^{394}$ Blitt, supra note 327. 
valid and binding international norm despite never having attained universal or near universal support. In the OIC's words, "the consistent pattern of safe passage of the [Combating Defamation of Religions] resolution [at the UN], by a majority vote beyond OIC membership, lends recognition and international legitimacy to the urgent need to combat defamation of religions." 395

Returning to the OIC's letter to the UNHRC president and High Commissioner, it closed by reasserting that a focus on SOGI would detract from other "glaring instances of intolerance and discrimination," 396 and that any such focus represented nothing less than an infringement of the VDPA. According to the OIC:

It must also be recognized that the international community agreed during the [1993 UN] World Conference on Human Rights...that while considering the issue of human rights, national and regional particularities and various historical, cultural and religious backgrounds must be borne in mind. From this perspective, the issue of sexual orientation is unacceptable to the OIC. 397

The framing of this final claim again exemplifies the OIC's penchant for distorting the substance of the VDPA and clinging instead to the Bangkok Declaration. ${ }^{398}$ Although the VDPA calls for bearing in mind the significance of religious and other particularities, the OIC ignores the fact that the Declaration does so only in the context of prioritizing "the duty of States, regardless of their political, economic and cultural systems, to promote and protect all human rights and fundamental freedoms." 399 In other words, while

395 OIC Res. No. 35/38, pmbl. (June 28-30, 2011). For a detailed account of the OIC's advocacy of defamation of religion as a valid international norm despite its discriminatory fallout, see Robert C. Blitt, Defamation of Religion: Rumors of Its Death Are Greatly Exaggerated, 62 CASE W. RES. L. REV. 347 (2011); Blitt, supra note 64. In arguing against recognition of SOGI rights, Egypt turned the OIC's rationale justifying a prohibition against defamation of religion on its head: "We can not ... accept the argument that reports submitted to a certain forum, even if it is the United Nations, or an adopted resolution, can be considered as an international human rights law instrument, thus paving the way for the creation of a new human right." Press Statement, Statement by Egypt During Interactive Dialogue with the Special Rapporteur on Freedom of Expression and the Special Rapporteur on Peaceful Assembly and Association, 26th Session of Human Rights Council (2014).

${ }^{396}$ Akram, supra note 382 . The OIC letter repeats on a more sweeping scale the dubious argument addressed above in the specific context of extrajudicial executions - that focusing on one vulnerable group detracts attention from other instances of discrimination.

${ }^{397} I d$.

398 See supra Part II(D)(1).

399 VDPA, supra note 62, ๆ I(5) (emphasis added). The IPHRC has eagerly adopted the OIC's disjointed interpretation, discarding the Vienna Declaration's recognition that states have a duty to protect all human rights regardless of state particularities. IPHRC Thematic Debate on "Protection of Family Values," supra note 192. According to the IPHRC, the VDPA "amply highlights the principle of due recognition and respect for cultural and religious diversity in the field and application of human rights." 
bearing in mind various particularities, the VDPA recognizes that states have a duty not merely to "consider" human rights, but actually to "promote and protect" them. During the UNHRC's first SOGI panel discussion-and not without some irony - the chair of Pakistan's Human Rights Commission (and former Special Representative of the UN Secretary-General on human rights defenders) Hila Jilani took pains to reiterate how little credibility the OIC's arguments carry: "Invoking culture or tradition as a shield for failure to protect individuals from human rights violations [is] unconvincing. States [are] not entitled to uphold human rights selectively or to exclude certain people from protection." 400

\section{UNHRC Resolution 27/32 on SOGI (2014)}

The UNHRC followed up on its SOGI-focused report and panel discussion with another contentious resolution in 2014. Resolution 27/32 reiterated the Council's grave concern over acts of violence and discrimination, and directed the OHCHR to update its 2012 report on discriminatory laws and practices targeting SOGI. ${ }^{401}$ In the lead up to the vote, OIC member states advocated amendments ${ }^{402}$ to the text that would have stripped all references to SOGI. The justifications for these changes were grounded in reasons identical to those outlined in the organization's 2012 letter to the UNHRC president. ${ }^{403}$ OIC states also expressed the conviction "that inviting individuals to identify themselves, or seek to be identified, in accordance with their private sexual conduct has no relationship with combating discrimination or violence, but on the contrary might result in further setbacks, create more resistance to States' efforts to eliminate all forms of discrimination, and might even subject individuals to more risks including violence and discrimination." ${ }^{404}$ Setting aside this abhorrent rationale (if the Baha'i didn't identify themselves or seek to be identified as Baha'i, they would be subject to less discrimination!), OIC member states also intimated that states supporting Resolution 27/32 attempted to coerce others into voting in favor of the measure: "many delegations members and non-members of the Council, were subjected to economic and political coercion ... to depart their national convictions and positions. This pattern of using reprisal techniques against States ... need[s]

\footnotetext{
400 SOGI Panel, supra note 378, ๆ 28.

${ }^{401}$ Human Rights Council Res. 27/32 (Oct. 2, 2014).

402 See Rep. of the Human Rights Council at the 27th Session, U.N. Doc. A/HRC/27/L.45A/HRC/27/L.51 (Dec. 22, 2014).

403 See e.g., Press Statement, Amr Ramadan, Statement on Introduction of Amendments on Draft Resolution L.27 [hereinafter Statement of Ambassador Amr Ramadan] ("Continuous attempts to parachute concepts and notions that lack universal consensus and definition or any basis in international human rights law, are not productive to the work of the Council, especially when they carry significant social, cultural, ethical, and religious sensitivities.").

${ }^{404} I d$.
} 
to stop immediately." 405 Supporters of the SOGI resolution rejected these allegations as "false" and "misleading." 406

As with the previous 2011 UNHRC resolution, OIC members in 2014 again represented the vast majority of UNHRC members-ten of 14-voting to oppose recognition of SOGI as a protected status. ${ }^{407}$ This acute isolation from the rest of the international community undermines the OIC's argument regarding the lack of consensus surrounding the issue. ${ }^{408}$ Such a position is rendered even less tenable in light of the findings contained in the OHCHR's updated SOGI report, released in May 2015. In addition to reiterating the protections affirmed by various international human rights treaty bodies, the OHCHR's report identified a parallel trend of recognition and endorsement across regional organizations in Africa, the Americas, and Europe:

In 2014, the African Commission on Human and Peoples' Rights passed a resolution in which it condemned violence and other human rights violations based on real or imputed sexual orientation and gender identity; the Organization of American States approved its seventh resolution on human rights, sexual orientation and gender identity . . .; the Inter-American Commission on Human Rights established the mandate of Rapporteur on the rights of LGBT and intersex persons ...; the European Union adopted guidelines on the promotion and protection of human rights of LGBT and intersex persons, and both the European Parliament and the Parliamentary Assembly of the Council of Europe adopted resolutions on the subject; and the European Court of Human Rights and the Inter-American Court of Human Rights issued several

\footnotetext{
405 Press Statement, Arab Republic of Egypt, General Comments, 27th Session of Human Rights Council Section. The Egyptian delegation first voiced this claim upon submission of amendments to the draft resolution: "Irrespective of the pressures and threats exerted in relation to this draft resolution against developing and least developed countries, including mine, to be coerced and walk the line ... Many States remain solidly proud of representing their societies and peoples." Statement of Ambassador Amr Ramadan, supra note 403. The delegate from Nigeria reiterated this sentiment, arguing that "Unlike the delegations that were exerting pressure on Nigeria because of its opposition to the use of the terms 'sexual orientation' and 'gender identity', his delegation was not seeking to impose its values on any other.” U.N. GAOR, 69th Sess., 53d meeting, ๆ 45, U.N. Doc. A/C.3/69/SR.53 (Jan. 16, 2015).

406 See infra Table 3. SOGI resolution sponsors responding to an amendment purporting to "[d]eplore the use of external pressures and coercive measures against States with the aim of influencing domestic debates." Id.

${ }^{407}$ See, H.R.C. Res. 27/32, supra note 401. Three other OIC states, Burkina Faso, Kazakhstan, and Sierra Leone, abstained. Id.

408 See e.g., U.N. GAOR, 69th Sess., supra note 405, ๆ $53-55$ (noting the statements from Iran, Bangladesh, Libya, and Sudan regarding UNHRC Resolution 27/32).
} 
judgements affirming the rights of LGBT persons to equal treatment and protection under the law. ${ }^{409}$

Despite this preponderance of recognition, the OHCHR grimly reported that "the overall picture remains one of continuing, pervasive, violent abuse, harassment and discrimination affecting LGBT and intersex persons in all regions. These constitute serious human rights violations, often perpetrated with impunity, indicating that current arrangements to protect the human rights of LGBT and intersex persons are inadequate." 410

Faced with these findings, the OHCHR report concluded:

States have well-established obligations to respect, protect and fulfil the human rights of all persons ... including LGBT and intersex persons. These obligations extend to refraining from interference in the enjoyment of rights, preventing abuses by third parties and proactively tackling barriers to the enjoyment of human rights, including ... discriminatory attitudes and practices. $^{411}$

But it is precisely these minimum obligations-of equality and nondiscrimination - that the OIC continues to reject out of hand.

Frustrated with its inability to derail SOGI protection efforts at the UN, the OIC moved to double down by way of issuing organizational resolutions aimed at deepening member state consensus with an eye to the future. OIC Resolution No. 4/42-C On Social and Family Issues saluted those states that voted against the UNHRC's second SOGI resolution, asserting that its content promoted "many issues which cannot be accepted as they are in total contradiction with the teachings and values of Islam and other divine religions and with the human common sense." 412 Resolution No. 4/42-C then spelled out the OIC's decisions to:

1. Reject the entire content of HRC Resolution [27/32] and to endeavor to take a unified Islamic and human position to repeal it.

2. Invite the ... (IPHRC) to take necessary measures towards the cancellation of the Resolution.

3. Invite the Secretary General to take necessary measures to repeal the Resolution.

4. Call on the [OIC] and its relevant institutions to provide the needed support to Member States undergoing pressure in this regard.

\footnotetext{
409 Discrimination and Violence Against Individuels Based on Their Sexual Orientation and Gender Orientation, supra note 181, ๆ 8.

${ }^{410} I d$. 76.

${ }_{411} I d$ 甲 10.

412 OIC Res. 4/42-C, supra note 180, ๆ A.
} 
5. Invite Member States to hold a specialized conference on the marriage and family institution and the preservation of their Islamic values. ${ }^{413}$

This move set the stage for open-ended conflict over the issues of SOGIbased rights and protection of the family at the UN. Putting aside the incongruous "human common sense" argument, Resolution 4/42-C drove home that underlying the multiple justifications proffered by the OIC, the overriding basis for denying recognition of SOGI lies in religious imperative.

Predictably, the IPHRC backed the OIC's position. IPHRC Commissioner Mostafa Alaei summarized the Commission's view on the possibility of SOGI rights thusly: "human rights [are] a way to protect the rights of Muslims, especially Muslims in Europe, not LGBT groups .... LGBT groups do not have human rights." ${ }^{414}$ More formally, the IPHRC betrayed its view that SOGI is unsuitable for rights protection from the outset when it established a working group tasked with examining -in its words - "the issue of human rights and that of the so-called 'sexual orientation' and any link between them." 415 This a priori confession should leave observers with the justifiable impression that any conclusions emanating from the IPHRC are likely to be pre-determined and utterly disconnected from IHRL. ${ }^{416}$

\section{UNHRC Resolution 32/2 on SOGI (2016)}

A third SOGI resolution introduced at the $32 \mathrm{~d}$ session of the UNHRC generated some of the fiercest debate to date over recognition of SOGI rights. ARC International, an NGO working to advance LGBT issues, produced a lengthy report compiling the OIC's numerous diplomatic maneuvers within the Council to thwart the resolution. Among these efforts, the OIC: attempted to outright preempt the resolution under UNGA procedural rule 116; proffered eleven separate amendments intended to void the resolution of SOGI-specific content; advanced a "last-ditch attempt" to oppose key parts of the text; and lastly, marshalled member states to vote against the final resolution itself. ${ }^{417}$

${ }^{413} I d$.

414 Anthony Tirado Chase, The Organization of Islamic Cooperation: A Case Study of InTERNATIONAL ORGANiZATIONS' IMPACT ON Human RIghtS 17 (Marie Juul Petersen \& Stephanie Larrick eds., 2015) (omission in original).

${ }^{415}$ OIC, Report of the 7th Session of the OIC Independent Permanent Human Rights Commission (IPHRC) 28 (Apr. 21, 2015) (noting the statement of Secretary General Ilham Ibrahim) (emphasis added). The IPHRC chairperson reiterated this framing later in the same address: "Our agenda items also include exploring the philosophical aspects of the concepts propounded by certain circles such as the so-called 'sexual orientation." $I d$. at 30.

${ }^{416}$ See infra note 463 and accompanying text. The IPHRC published a formal study on SOGI rights in May 2017.

${ }^{417}$ Allied Rainbow Cmtys., Int'l \& Int'l Lesbian, Gay, Bisexual, Trans and Intersex Ass'n, Compilation of the Adoption of the 2016 SOGI Resolution 3 (2016), [hereinafter Compilation of the Adoption of the 2016 SOGI Resolution]. The amendment efforts are also summarized in the Report 
The substance of the OIC's amendments, reaction from the sponsors of the SOGI resolution, and voting outcomes are summarized in the table below.

\section{Table 3: OIC-sponsored Amendments to the 2016 UNHRC SOGI Resolution, Objections \& Voting Outcomes}

\begin{tabular}{|c|c|}
\hline Amendment \# / Purpose & \multirow{2}{*}{ Outcome } \\
\hline Primary Objection Raised by SOGI Resolution Sponsors & \\
\hline L.71: Change resolution title to delete reference to SOGI. & \multirow[b]{2}{*}{$\begin{array}{c}\text { Defeated } \\
17-18-9\end{array}$} \\
\hline $\begin{array}{l}\text { "All that is intended by modifying the title is to hide the specificity and the very nature of the } \\
\text { draft resolution.... Approv[al]... will amount to erasing the word 'racism' in a resolution } \\
\text { on racism...." } 418\end{array}$ & \\
\hline L.72: Delete references to prior UNHRC SOGI resolutions (17/19 and 27/32). & \multirow[b]{2}{*}{$\begin{array}{l}\text { Defeated } \\
17-18-9\end{array}$} \\
\hline $\begin{array}{l}\text { "[A] vote in favor [of] this amendment is a vote against the need to enhance the protection } \\
\text { against violence and discrimination directed at the people who are solely targeted for their } \\
\text { sexual orientation and gender identity." } 419\end{array}$ & \\
\hline L.73: Call for joint ownership of the international human rights agenda. & \multirow{2}{*}{$\begin{array}{l}\text { Passed } \\
24-17-4\end{array}$} \\
\hline $\begin{array}{l}\text { "[C]ompletely unacceptable ... . because .... [it] implies that the resolution as drafted is } \\
\text { non-objective and it is confrontational when it is totally the opposite." } 420\end{array}$ & \\
\hline $\begin{array}{l}\text { L.74: Undertake to support broad and balanced agenda, and to strengthen the mechanisms } \\
\text { addressing issues of importance. }\end{array}$ & \multirow[b]{2}{*}{$\begin{array}{l}\text { Passed } \\
23-17-5\end{array}$} \\
\hline 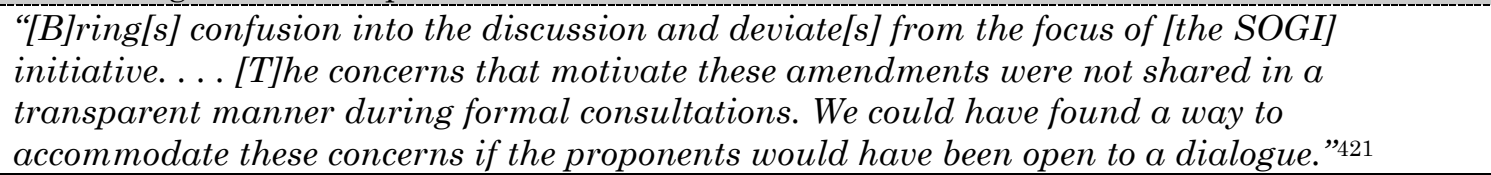 & \\
\hline L.75: Reiterate the importance of respecting regional, cultural and religious value systems. & \multirow[b]{2}{*}{$\begin{array}{l}\text { Passed } \\
20-18-6\end{array}$} \\
\hline $\begin{array}{l}\text { "The proposed amendment is a misquotation of Article } 5 \text { of the Vienna Declaration and } \\
\text { Programme of Action." } 422\end{array}$ & \\
\hline $\begin{array}{l}\text { L.76: Underline fundamental importance of respecting relevant domestic debates at the } \\
\text { national level on matters associated with historical, cultural, social and religious } \\
\text { sensitivities. }\end{array}$ & \multirow{2}{*}{$\begin{array}{l}\text { Passed } \\
21-17-7\end{array}$} \\
\hline $\begin{array}{l}\text { Proposed amendment is an "attempt to reinterpret the [VDPA]" and introduces "language } \\
\text { which would restrict the universality of human rights and fundamental freedoms." } 223\end{array}$ & \\
\hline $\begin{array}{l}\text { L.77: Deplore the use of external pressures and coercive measures against States with the } \\
\text { aim of influencing domestic debates. }\end{array}$ & $\begin{array}{l}\text { Passed } \\
23-18-4\end{array}$ \\
\hline
\end{tabular}

\footnotetext{
of the Human Rights Council on its thirty-second session. Rep. of the Human Rights Council on its Thirty-Second Session, ๆ $169-226$, U.N. Doc. A/HRC/32/2 (Nov. 14, 2016).

418 Compilation of the Adoption of the 2016 SOGI Resolution, supra note 417, at 28.

${ }^{419} I d$. at 32

${ }^{420} I d$. at 34

${ }^{421} \mathrm{Id}$. at 38

${ }^{422} I d$. at 40 .

${ }^{423}$ Compilation of the Adoption of the 2016 SOGI Resolution, supra note 417, at 44-45.
} 


\begin{tabular}{|c|c|}
\hline Amendment \# / Purpose & \multirow{3}{*}{ Outcome } \\
\hline Primary Objection Raised by SOGI Resolution Sponsors & \\
\hline $\begin{array}{l}\text { "II]ntroduce[s] the false idea that the draft resolution tries to use economic sanctions and } \\
\text { coercive measures to undermine the authority of States to determine and influence their own } \\
\text { decision-making process. This is totally misleading." } 424\end{array}$ & \\
\hline $\begin{array}{l}\text { L.78: Express concern at any attempt to undermine the international human rights system } \\
\text { by seeking to impose concepts or notions pertaining to social matters, including private } \\
\text { individual conduct, that fall outside the internationally agreed human rights legal } \\
\text { framework. }\end{array}$ & \multirow{2}{*}{$\begin{array}{l}\text { Passed } \\
18-17-9\end{array}$} \\
\hline $\begin{array}{l}\text { "The amendment pretends to affirm that the sponsors of the resolution are trying to impose } \\
\text { concepts or notions pertaining to social matters. We firmly reject this affirmation. The } \\
\text { objective of this initiative is the opposite." } 425\end{array}$ & \\
\hline $\begin{array}{l}\text { L.79: Underline resolution should be implemented while ensuring respect for the sovereign } \\
\text { right of each country as well as its national laws, development priorities, the various } \\
\text { religious and ethical values and cultural backgrounds of its people. }\end{array}$ & \multirow{2}{*}{$\begin{array}{l}\text { Passed } \\
22-17-5\end{array}$} \\
\hline $\begin{array}{l}\text { "[P]laces national sovereignty and cultural relativism over the universality of human rights. } \\
\text { Human rights are universal, and allegations of national sovereignty should not, and cannot, } \\
\text { be invoked to perpetrate human rights violations." }{ }^{26}\end{array}$ & \\
\hline $\begin{array}{l}\text { L.80: Modify second operative paragraph to delete specific reference to sexual orientation } \\
\text { and gender identity and instead deplore acts of violence and discrimination in all regions of } \\
\text { the world generallv. }\end{array}$ & \multirow{2}{*}{$\begin{array}{c}\text { Defeated } \\
17-19-8\end{array}$} \\
\hline $\begin{array}{l}\text { "[T] he proposed amendment . . . seeks to transform [operative paragraph 2] into a statement } \\
\text { of such generality that [it] loses the original focus and purpose." } 427\end{array}$ & \\
\hline $\begin{array}{l}\text { L.81: Substitute operative paragraphs creating mandate for independent expert on SOGI } \\
\text { with request for an OHCHR report on the protection of all individuals against violence and } \\
\text { discrimination. }\end{array}$ & \multirow[b]{2}{*}{$\begin{array}{c}\text { Defeated } \\
17-19-8\end{array}$} \\
\hline $\begin{array}{l}\text { This amendment "is an attack to the heart of this draft resolution. This amendment } \\
\text { completely rewrites the resolution-deleting six paragraphs, stripping all references to sexual } \\
\text { orientation and gender identity, and eliminating the creation of [an independent expert] } \\
\text { mechanism." } 428\end{array}$ & \\
\hline
\end{tabular}

As can be seen from the table above, several of the OIC's amendmentsincluding provisions distorting the substance of the VDPA and universality of human rights-made their way into the final 2016 SOGI resolution. However, the organization's concerted effort to strip the resolution's references to SOGI and dismantle the creation of a new independent expert mandate on SOGI failed. Even before voting, the OIC informed UNHRC members that it would "not be able to support an Independent Expert for a concept that has not yet

${ }^{424} I d$. at 46.
${ }^{425} I d$. at 50.
${ }^{426} I d$. at 54.
${ }^{427} I d$. at 58.
${ }^{428}$ Compilation of the Adoption of the 2016 SOGI Resolution, supra note 417 , at 63 . 
been adopted by any universal intergovernmental negotiated treaty or convention." 429

Individual OIC member states also invoked a variety of the now familiar justifications to explain their respective positions. Saudi Arabia claimed "a mismatch between the behaviors of individuals on one hand and our sacred values consecrated by religion on the other hand." ${ }^{430}$ Nigeria "seriously object[ed] to LGBT rights as human rights . . . because it offend[ed] their culture, religion and natural laws." 431 Indonesia expressed concern the resolution "link[ed] the discussion on discrimination and violence with a concept that is divisive and lacks of recognition to the different norms, cultures and views of other societies." 432 Morocco touched on protection of the family and religious primacy, claiming the resolution would "create an ambiguity for the youth," and-appearing to speak for all Muslims—run "against the values and the beliefs of at least 1.5 billion that belong to one civilization." ${ }^{433}$ The representative further raised the specter that the resolution would usher in "the beginning of a very dark period in the life of the Council," and augured "a war between civilizations and religions." 434

The final 2016 UNHRC resolution as amended passed the Council 23 to 18, with OIC states representing 15 of the dissenting votes. ${ }^{435}$ Two days later, an OIC communiqué invoked the organization's revisionist and relativist justifications for "strongly reject[ing] the resolution," claiming "the notion of sexual orientation is alien to the international human rights norms and standards as well as against the fundamental precepts of not only Islamic but many other religious and cultural societies." 436 Again distorting the VDPAand despite the amendments successfully inserted in the resolution's preamble- the OIC insisted that the resolution "amounts to imposing one set of values and preferences on the rest of the world and counteracts the

${ }^{429} I d$. at 17 (emphasis removed).

${ }^{430} I d$. at $87-88$.

${ }^{431} I d$. at 91 .

${ }^{432}$ Press Statement, Representative from Indonesia to the $32 \mathrm{~d}$ Session of the United Nations Human Rights Council, Explanation of Vote: The Delegation of Indonesia on Adoption of the Draft Resolution L.2 On Protection Against Violence and Discrimination Based on Sexual Orientation and Gender Identity (SOGI), I 2 (June 30, 2016) (on file with author).

${ }^{433}$ Compilation of the Adoption of the 2016 SOGI Resolution, supra note 417, at 96.

${ }^{434} I d$.

${ }^{435}$ Human Rights Council Res. 32/2 (July 15, 2016); Compilation of the Adoption of the 2016 SOGI Resolution, supra note 417, at 93-94. Albania, the only OIC state that voted in favor, reasoned that the resolution did not "seek to create any new rights but simply affirms the application of existing human rights standards to those who are discriminated and abused because of who they are." Albania's comments failed to address the religious arguments voiced by other OIC states.

${ }^{436}$ OIC, OIC Strongly Rejects HRC Resolution on Sexual Orientation and Gender Identity (July 2, 2016), http://www.oic-oci.org//topic/ampg.asp?t_id=11338\&t_ref=4456\&lan=en. 
fundamentals of universal human rights that call for respecting diversity, national and regional particularities." 437

Apparently unsatisfied with the communiqué alone, OIC Member States in Geneva subsequently issued an additional declaration condemning Resolution 32/2 that went even further. Purporting to speak on behalf of all Muslims, the declaration asserted that the "highly divisive" resolution "aims to impose a set of values on the world, which . . . contradicts . . . the beliefs of at least more than 1.5 billion Muslims." 438 Furthermore, it tied OIC opposition to SOGI back to protection of the family, "reaffirm[ing] that the natural family - consisting of a man and a woman-is the main part of the society with a unique role in ensuring healthy live [sic] and well-being of all its members especially children." ${ }^{439}$

The OIC's assertion that Resolution 32/2 "contradicts" and is "against the values and the beliefs" of all Muslims everywhere is shocking as much for its inaccuracy as it is for its arrogance. It bears pausing here to reaffirm the reality that the OIC-despite claiming and wanting it to be so-does not represent the sole or final word on the interpretation of Islamic law. In fact, a variety of Muslim NGOs advocate for a progressive interpretation of Islam or on behalf of LGBT Muslims globally. For example, Muslims for Progressive Values, a U.S.-based NGO with consultative status at the U.N., "endorse[s] the human and civil rights of lesbian, gay, bisexual, transgender, queer, and intersex (LGBTQI) individuals" and is "committed to ending discrimination based on sexual orientation and gender identity." 440 Similarly, the Alliance of Inclusive Muslims ("AIM"), "a collective of progressive Muslims across all nationality, race and sectarian affiliation[s] . . . seeks to challenge theological justifications for hate and supremacism" with what it describes as "progressive values . . . inherent in Islam." ${ }^{41}$ Among its priorities, AIM advocates for human rights and dignity, including "[r]ecognizing each individual's equal worth in society and right to equal protection under the law." 442

${ }^{437} I d$.

438 OIC, Declaration by the Group of the OIC Member States in Geneva on Condemning the Human Rights Council Resolution "Protection Against Violence and Discrimination Based on Sexual Orientation and Gender Identity," at 68, OIC Doc. OIC/CFM-43/2016/CS/RES/FINAL Annex 1, (Oct. 18-19, 2016).

439 Id. at 69 .

${ }_{440}$ MPV Principles, MusLims For PROGRessive VALUes, http://www.mpvusa.org/mpv-principles/ (last visited Nov. 21, 2018).

${ }^{441}$ About AIM, ALliance of InCLUSIVE Muslims, https://aim.ngo/about/ (last visited Nov. 21, 2018).

${ }_{442} I d$. These organizations are part of a larger network of related groups supporting LGBTI communities and issues globally, as well as in OIC member states. See generally SCOTT SIRAJ ALHaqq Kugle, Living OUT Islam: Voices of Gay, Lesbian, and TransGender Muslims (2014), (documenting numerous support groups and other organizations working within Muslim LGBT circles); Munir Shaikh, Contemporary Developments within Muslim Societies and Communities regarding LGBT Identity and Rights, in MUSLIM LGBT INCLUSION PROJECT (2011) (on file with 
Likewise, certain Muslim academics have continued to advance interpretations of Islam that contradict the OIC's take on SOGI. Much of this scholarship is premised on affirmations like El-Fadl's that "the commitment to human rights does not signify a lack of commitment to God, or a lack of willingness to obey God. Rather, human rights become a necessary part of celebrating human diversity, honoring the vicegerents of God, achieving mercy, and pursuing the ultimate goal of justice." ${ }^{443}$ More specifically, this body of work engages SOGI-related issues using Islamic sources, and thus represents a distinctively Muslim counter-narrative to the OIC and its asserted claim to represent the "collective" voice of the Muslim world.

Self-described "progressive Muslim" scholars such as Omid Safi, assert a "determination to hold Muslim societies accountable for justice and pluralism ... exposing the violations of human rights . . . and the right to dissent in Muslim countries ... [and] embracing and implementing a different vision of Islam than that offered by Wahhabi and neo-Wahhabi groups." ${ }^{444}$ As explained by Adis Duderija, this approach "seek[s] to weave the ethos and the culture of human rights discourse into the social and cultural fabric of Muslim-majority societies in order for those rights to be more effectively realized in the political and legal realms of these societies." 445

Similarly, Scott Siraj al-Haqq Kugle calls for a "revived 'Islamic humanism" to "encourage reform of Islamic law as a framework for ethical living in creative engagement with modern conditions." ${ }^{446}$ In Kugle's

the author) (summarizing numerous LGBT rights organizations in Muslim-majority nations and elsewhere); Brian Whitaker, Everything You Need to Know About Being Gay in Muslim Countries, GUARDIAN (June 21, 2016, 6:30 AM), https://www.theguardian.com/world/2016/jun/21/gay-lgbtmuslim-countries-middle-east (noting gay rights groups in various OIC states as well as "a handful of gay-friendly mosques and a few openly gay imams" based outside of OIC states).

${ }^{443}$ Khaled Abou El-Fadl, Islam and the Challenge of Democratic Commitment, 27 FoRDHAM INT'L L.J. $4,52-53$

$[\mathrm{I}] \mathrm{it}$ is not the pre-modern juristic tradition that poses the greatest barrier to the development of individual rights in Islam. Rather, the most serious obstacle comes from modern Muslims themselves. Especially in the last half of the past century, a considerable number of Muslims have made the unfounded assumption that Islamic law is concerned primarily with duties, and not rights, and that the Islamic conception of rights is collectivist, not individualistic. Both assumptions, however, are not based on anything other than cultural assumptions about the non-Western 'other.' It is as if the various interpreters decided on what they believe is the Judeo-Christian, or perhaps Western, conception of rights, and then assumed that Islam must necessarily be different. (internal citations omitted).

${ }^{444}$ Safi, supra note 144 , at 2 . Safi's volume also contains a bibliography of "alternative" reading suggestions for developing a "deeper, more challenging, and nuanced understanding of Islam." Id. at 333 .

445 Duderija, supra note 229, at 69; see generally ADIS DUDERIJA, ThE IMPERATIVES OF PROGRESSIVE ISLAM (2017).

446 Scott SiRaj AL-Haqq Kugle, Homosexuality in Islam: Critical Reflection on Gay, LESBIAN, AND TRANSGENDER MUSLIMS 271 (2009). 
assessment, "[a]n honest and subtle examination" of Islamic religious beliefs on sexuality and its diversity "reveals more ambiguities than the defenders of 'orthodoxy' care to admit." ${ }_{447}$ Such an approach, however, is frustrated by a "potent combination of patriarchal custom and theological belief" that prevents "many Muslims from seeing their lesbian, gay and transgender fellow citizens as fully human and therefore deserving compassion and demanding justice." 448 For Kugle, correcting this lacuna demands "a deep reform of Islamic belief and action" 449 that can be derived from "[a] 'sexually-sensitive' interpretation of the Koran" able to account for the reality of sexuality and sexual orientation among Muslims:

[This] interpretation would be explicitly non-patriarchal. It would not presume patriarchal values of male supremacy; it would not assume that all readers of Qur'an are (or should be) heterosexual in orientation. It would avoid imposing ideas of human nature that are obsolete (such as medieval Muslim assumptions ....). In this sense, sexuality-sensitive interpretation of the Qur'an would complement and support gender-sensitive interpretation of the scripture ... as well as race-sensitive and class-sensitive interpretations. ${ }^{450}$

Utilizing this interpretive approach to Islamic sources generates outcomes diametrically opposed to the OIC view, including validating the recognition of same-sex marriage under Islamic law. A recent study by Junaid Jahangir and Hussein Abdullatif argues that the predominant Muslim "position on same-sex unions is not based on express texts but derived on the basis of analogy and alleged consensus, both of which are contested branches of Islamic

${ }_{447}$ Scott Siraj al-Haqq Kugle, Sexuality, Diversity, and Ethics in the Agenda of Progressive Muslims, in Progressive MusLIMs, supra note 144, at 190, 194. According to Kugle, given "the Qur'an's vivid portrayal of diversity at so many levels of the natural and human world, it would be logical to assume that this diversity of creation plays out on the level of sexuality as well." Id. at 196 .

448 KUGLE, supra note 442 , at 232. Among other things, Kugle rejects the claim that marriage is grounded in procreation and therefore rightly limited to heterosexual couples only: "This argument does not arise from within the Islamic tradition itself, because most Muslims in the past did not limit the purpose of sexual pleasure to procreation even if they valued procreation very highly." Id. at 200. Further stating that:

adjustments to the nikah [standard marriage] contract envisioned by [LGBT] Muslims are analogous to those envisioned by feminists who focus more exclusively on women's rights ... . The underlying obstacle to the full participation of gay and lesbian believers in marriage is the inequality in gender roles that patriarchy enforces, rather than specifically the issue of sexual orientation.

$I d$. at 211; see also id. at 221 (discussing the lives of LGBT Muslims living in secular democratic states and their efforts to reclaim their faith: "activists believe that the ideals of Islam can be distilled from the traditional forms of the religion and reworked into a new form that accepts more social pluralism and individual rights, including diversity in sexual orientation and gender identity").

${ }_{449} I d$. at 232.

${ }^{450}$ KUGLE, supra note 446 , at 41. 
knowledge." 451 Instead, Jahangir and Abdullatif posit these same sources "can be marshaled to affirm gender and sexual diversity," and that an interpretation rejecting the possibility of same-sex marriage as clearly prohibited is "fallacious ... especially when such a view is not based on express texts but derived from a story of exploitation and coercion." ${ }^{452}$ The authors conclude that because Islamic tradition offers "no express position on same-sex unions ... the case for Muslim same-sex unions can be justified on the basis of [the] juristic principle of repelling harm and also by extending from the precedent of the marriage of the khuntha mushkil (indeterminate gender) to the non-binary case where sexual orientation traverses anatomy." 453 According to their final assessment, "Muslim scholars can delve freshly, sensitively and widely into their rich heritage to affirm Muslim same-sex unions." 454

\section{OIC Efforts to Rollback the 2016 UNHRC SOGI Resolution}

Not satisfied with its own protest statements, the OIC sponsored a variety of additional efforts intended to stymie the UNHRC vote and derail the SOGI independent expert mandate. The Egyptian delegate to the UNHRC's Consultative Group, the body responsible for developing candidate pools for filling various mandates, wrote to inform the UNHRC President of his decision to withdraw from "the work of the Consultative Group relevant to its upcoming recommendation on the selection of [the SOGI] mandate-holder." 455 In withdrawing, Ambassador Ramadan offered the circular assertion that "the creation of this mandate is in Ulta [sic] Vires to international human rights law and is beyond universally recognized human rights and fundamental freedoms in a manner that amounts to utter disregard to the principle of universality of internationally agreed human rights." 456

At the end of September 2016, the UNHRC closed its 33d session by endorsing new mandate holders, including Mr. Vitit Muntarbhorn from

\footnotetext{
451 Junaid Jahangir \& Hussein Abdullatif, Same-Sex Unions in Islam, 24 THEOLOGY \& SEXUALITY 157, 158 (2018).

${ }^{452} I d$.

${ }^{453} I d$.

${ }^{454} I d$. at 168 .

${ }^{455}$ Letter from Ambassador Amr Ramadan, Permanent Representative of Egypt, to President of the Human Rights Council (July 29, 2016).

${ }^{456} I d$. One might ask whether a parallel exists between the ambassador's expressed sense of dread "engag[ing] in an exercise which is contrary to [his] convictions and the values [he] stands for," and the actual humiliation and inhuman treatment meted out by the ambassador's government in subjecting its citizens to forced anal examinations in the course of prosecuting them on charges relating to their alleged sexual orientation. Compare id., with Mandates of the Working Group, supra note 345; Dignity Debased: Forced Anal Examinations in Homosexuality Prosecutions, HuM. RTS. WATCH (Jul. 12, 2016), https://www.hrw.org/report/2016/07/12/dignity-debased/forced-analexaminations-homosexuality-prosecutions (reporting on eight countries, including Egypt, where "law enforcement officials working in tandem with medical personnel subject men and transgender women who are arrested on homosexuality-related charges to forced anal examinations, with the purported objective of finding 'proof' of homosexual conduct.").
} 
Thailand as the first Independent Expert on protection against violence and discrimination based on sexual orientation and gender identity. ${ }^{457}$ Saudi Arabia, speaking on behalf of the OIC (except Albania), again reiterated the organization's opposition to the mandate, expressing concern "over the introduction of topics that were not universally agreed on, and which impinged on religious sensitivities." Further to this, the Saudi representative formally asserted the OIC would "not recognize the establishment of the mandateholder and would boycott the Independent Expert." ${ }^{58} 8$ Still, the OIC was not finished with the matter.

\section{Reaction of the 43d OIC Conference of Foreign Ministers}

The OIC used its 2016 resolution on "Social and Family Issues" to build out its operative rejection of the UNHRC's SOGI-related efforts. This resolution reaffirmed the OIC's view "that issues related to sexual orientation etc. have no link to human rights" 459 and its position "of non-recognition of and noncooperation" with the UN's new SOGI independent expert. ${ }^{460}$ The resolution also renewed the demand that the OIC Secretary General "take necessary measures to repeal" the UNHRC's SOGI resolution. ${ }^{461}$ Further, it called on Member States "to make all efforts to oppose the adoption of a resolution on sexual orientation" at the UNGA's 71st Session. ${ }^{462}$

In addition to these measures, the 2016 resolution on social and family issues also requested the IPHRC study the issue of SOGI "in the light of Islamic and human rights framework and present its recommendations to the CFM on how to address the issue." 463 Lastly, the OIC linked for the first time its efforts to deny SOGI recognition in the context of protection of the family

${ }^{457}$ See Press Release, U.N. High Comm'r for Hum. Rts., Human Rights Council Adopts Six Resolutions, Appoints Special Procedures Mandate Holders and Closes Its Thirty-Third Regular Session (Sept. 30, 2016), https://www.ohchr.org/en/NewsEvents/Pages/DisplayNews.aspx?NewsID=20627\&LangID=E (describing that the UNHRC president presented the candidate recommended and ranked first by the Consultative Group).

${ }^{458} I d$.

${ }_{459}$ OIC Res. 4/43-C, ๆ A(4) (Oct. 18-19, 2016).

${ }_{460} I d .9 \mathrm{~A}(5)$.

${ }^{461} I d . \uparrow \mathrm{A}(6)$.

462 Id. ๆ $\mathrm{A}(4)$.

${ }^{463} I d$. I $\mathrm{A}(8)$. The IPHRC published a 10-page report elaborating its views on sexual orientation in May 2017. Indep. Permanent Hum. Rts. Commission [IPHRC], OIC-IPHRC Study on Gender Identity in the Light of Islamic Interpretations and International Human Rights Framework (May 2017), https://docplayer.net/72150384-Oic-iphrc-study-on-sexual-orientation-and-gender-identityin-the-light-of-islamic-interpretations-and-international-human-rights-framework.html. The author provides a critical assessment of the IPHRC's analysis and conclusions elsewhere. See generally Robert C. Blitt, Leveraging Regional Human Rights Mechanisms Against Universal Human Rights: The OIC Independent Permanent Human Rights Commission Study on Sexual Orientation, 60 WM. \& MARY L. REV. ONLINE 1 (2018). 
with its larger opposition campaign, by formally welcoming and taking credit for the UNHRC's protection of the family resolutions. ${ }^{464}$

\section{An Eleventh-Hour Effort to Derail the SOGI Resolution at the UN General Assembly}

Several weeks after the OIC's Conference of Foreign Ministers, the normally routine adoption of a formulaic UN General Assembly resolution acknowledging the UNHRC's annual report morphed into an eleventh-hour effort to cancel Resolution 32/2. The Group of African States introduced a resolution calling for deferral of action on the SOGI resolution, contending "further consultations" were necessary to determine the legal basis for the special procedure's mandate. ${ }^{465}$ The Russian Federation joined OIC states Pakistan, Qatar, Saudi Arabia, the United Arab Emirates, and Yemen in sponsoring the draft resolution. ${ }^{466}$ If accepted, the deferral would effectively thwart operation of the newly appointed independent expert and signal the first time the UNGA elected to override a validly passed UNHRC measure.

The statement accompanying the African Group's proposal to torpedo the SOGI Independent Expert rehashed many of the same justifications the OIC proffered previously: that recognition of SOGI would "impose new notions and concepts that are not internationally agreed upon"; that focusing on SOGI would ignore "intolerance and discrimination" that exists on the basis of colour, race, sex or religion; and that such recognition "could result in negative discrimination at the expense of other internationally agreed rights." Like the OIC, the African Group claimed that SOGI issues amounted to a domestic concern and therefore ran counter "to the commitment in the United Nations Charter to respect the sovereignty of States and the principle of nonintervention." 467

Reaction from supporters of Resolution 32/2 was predictably swift. During a debate in the Third Committee, the representative of Ireland called the African Group's effort "an unwarranted attempt to subvert a legitimate decision of the Council and created an unnecessary and dangerous precedent, allowing for Council resolutions to be questioned or reopened by the General Assembly." 468 The United States similarly decried the "unprecedented attempt

${ }^{464}$ OIC Res. 4/43-C, supra note 459, $9 \mathrm{~A}(10)$ (noting the protection of the family resolutions were "adopted over the last three years at the initiative of Egypt and ... supported by the overwhelming majority of the OIC Member States.").

${ }^{465}$ Rep. of the Human Rights Council, ๆ 2, U.N. Doc. A/C.3/71/L.46 (Nov. 3, 2016).

${ }^{466}$ Rep. of the Human Rights Council, ๆ 9 5-6, U.N. Doc. A/71/479 (Dec. 5, 2016). These sponsors are in addition to the 27 OIC states that make up half of the Group of African States at the UN. $I d$.

${ }^{467}$ Rep. of the Human Rights Council, q $4-5$ (2016) (on file with the author).

${ }^{468}$ U.N. GAOR, 71st Sess., Rep. of the Human Rights Council, 45th mtg. I 25, U.N. Doc. A/C.3/71/SR.45 (Nov. 4, 2016). The EU representative warned the measure threatened "the delicate institutional relationship" between the UNHRC and the General Assembly: "The creation 
to reopen a Human Rights Council mandate" as "inconsistent with respect for the Council's ability to function" and "a dangerous precedent." 469

The UNHRC's Coordination Committee of Special Procedures likewise warned that if successful, the deferral resolution would place the SOGI Independent Expert mandate "in a legal and political vacuum," "undermine[] . .. the Council's credibility and authority, and weaken[] . . . the human rights system as a whole." 470 The Committee underscored that "the creation of special procedures mandates falls squarely within the mandate of the Human Rights Council" rather than the UNGA. Accordingly, states should "recognize their responsibility to preserve the human rights system and ensure that the Independent Expert is able to continue fulfilling his mandate without hindrance and with the full cooperation of all States and other stakeholders." 471 In an open letter to UN member states on behalf of nearly $800 \mathrm{NGOs,} \mathrm{the}$ International Service for Human Rights ("ISHR") summarized the dynamic triggered by the last ditch effort to terminate the nascent SOGI Independent Expert mandate:

If the Third Committee were able to reopen the Council's annual report and select which resolutions it supports and which it seeks to block, even through the pretext of deferment, it would fundamentally undermine the authority granted to the Council by the General Assembly. In effect, this would open all Council resolutions up to renegotiation and debate at Third Committee every year, and have far-reaching implications well beyond the specific resolution currently under consideration. ${ }^{472}$

Within days, over fifty states sponsored an amendment to the African Group's resolution, proposing to "Delete operative paragraph 2" and thereby effectively erase the attempt to defer approval of the UNHRC's SOGI resolution. ${ }^{473}$ During the final heated debate preceding the vote, the African Group sought to dismiss the claim that deferral of an UNHRC resolution was

of special procedures was well within the Council's purview and should not be reopened by the General Assembly, lest the functioning of the Council and the work of its member States be seriously called into question.” Id. ๆ 28.

${ }^{469} I d$. 73.

470 “Deep Concern" at Bid to Block UN Human Rights Expert, U.N. High Comm'R FOR Hum. RTS. (Nov. 21, 2016), http://www.ohchr.org/EN/NewsEvents/Pages/DisplayNews.aspx?NewsID=20902\&LangID=E.

${ }^{471} I d$.

472 Defend the Independence of the UN Human Rights Council, INT'L SERV. FOR HUMAN RIGHTS (Nov. 21, 2016), https://www.ishr.ch/news/defend-independence-un-human-rights-council; see also List of Signatories: Overview, INT'L SERVICE FOR HuM. RTS. (Nov. 21, 2016), https://www.ishr.ch/sites/default/files/documents/nov21_2016_finallist_signatoriesunga3committ ee.pdf (setting out the list of 799 signatory organizations and noting that NGOs from Latin America, Africa, and the Asia-Pacific region accounted for nearly 500 of these organizations).

${ }^{473}$ U.N. GAOR, 71st Sess., Rep. of the Human Rights Council, U.N. Doc. A/C.3/71/L.52 (Nov. 8, 2016). 
unprecedented. To do so, it relied on the assertion that the UNGA previously had deferred consideration of UNHRC Resolution 1/2 on the United Nations Declaration on the Rights of Indigenous Peoples (UNDRIP). ${ }^{474}$

These two situations are readily distinguishable on several grounds. In the first instance, UNHRC Resolution 1/2 recommended that the General Assembly adopt a resolution endorsing UNDRIP, ${ }^{475}$ a declaration intended to set out an international "standard of achievement to be pursued" in the context of indigenous rights. ${ }^{476}$

The General Assembly's decision to defer consideration of UNDRIP fell squarely within its ambit. Under the terms of Resolution 1/2, the UNHRC merely transmitted a recommendation to the Assembly, rather than a duly authorized institutional decision to establish a new human rights special procedure. Moreover, approval of the UNDRIP resolution-signaling endorsement of an international declaration with the potential for impacting international law-falls squarely within the UNGA's remit under the UN Charter. Article 13 of the UN Charter establishes that the General Assembly maintains authority to make recommendations for: "promoting international co-operation in the political field and encouraging the progressive development of international law and its codification." 477

Beyond these differences, the nature of deferral sought in each instance is also dissimilar. In 2006, when the UNGA approved its deferral of consideration of UNHRC Resolution 1/2, it required that any additional consultations conclude before the close of the same 61st session of the General Assembly. ${ }^{478}$ In contrast, the African Group's proposal contained no parallel expiration or deadline but instead was formulated as an open-ended deferral of the SOGI mandate.

The Egyptian representative, speaking on behalf of the OIC (with the exception of Albania), repeated the organization's revisionist and relativist arguments, asserting that extending protection on the basis of SOGI had "no foundation in international human rights law" and "directly impinged on the social, cultural and religious sensitivities of a large number of countries . . . " 479 The delegate concluded by asserting that the failure to vote in favor of deferral "would ensure that OIC would continue to boycott the Independent Expert and would not be in a position to cooperate with that expert." 480 Appearing to forget that for a decade the OIC regularly advanced resolutions

\footnotetext{
${ }^{474}$ U.N. GAOR, 71st Sess., 53rd mtg. ๆ 19, U.N. Doc. A/C.3/71/SR.53 (Nov. 21, 2016).

${ }^{475}$ Human Rights Council Res. 1/2, ๆ 2 (Nov. 11, 2006).

476 G.A. Res. 61/295, pmbl., (Oct. 2, 2007).

477 U.N. Charter art. 13(1)(a).

478 G.A. Res. 61/178, ๆ 3 (Mar. 6, 2007).

479 U.N. GAOR, 71st Sess., supra note 474

${ }^{480} I d$. $\mid 31$.
} 
condemning "defamation of religion" in the UNHRC and UNGA without providing any legal definition for the far more mercurial term, ${ }^{481}$ Yemen and Libya (among others) added that the SOGI resolution could not be allowed to proceed without "a legal definition of sexual orientation or gender identity ... .$"{ }^{4} 82$

The amendment deleting the operative paragraph from the African Group's resolution passed by " 84 votes to 77, with 17 abstentions." 483 Following the vote, the OIC again "unequivocally rejected the establishment of a mandate for the Independent Expert" and again declared it "would not be in a position to cooperate or engage with the mandate-holder." 484

3. OIC Ministerial Conference on Strengthening Marriage and Family Institution and Preserving its Values in Member States

The OIC's first "Ministerial Conference on Strengthening Marriage and Family Institution and Preserving its Values in Member States" convened in Jeddah in February 2017, only months after the prickly General Assembly vote and nearly ten years after the OIC first established its Department of Family Affairs. ${ }^{485}$ Several resolutions that emerged from the conference merit attention here. The first urgently called for the need to develop an "OIC Strategy for Empowerment of Marriage and Family Institution and Preservation of its Values in the Muslim World," based on prior IPHRC recommendations made in this area. ${ }^{486}$ Recall that the IPHRC's 2015 meeting on "Protecting Family Values" endorsed a definition of family premised on "a long-term consensual relationship between a man and a woman who are bound by the reciprocal rights and responsibilities enshrined in Islamic teachings." 487 The IPHRC further "condemned the growing trend of confusing the definition of family with new and controversial notions of LGBT families based on sexual orientation that were neither universal nor recognized by international human rights standards." ${ }^{88}$ Recommendations that emerged from this 2015 session included, for example, opposing UN publications that "elaborate on the socalled notion of sexual orientation and comprehensive sexuality education," and urging the UN and other human rights institutions to "put the family at

${ }^{481}$ Blitt, supra note 327, at 16 ("The problem of providing a workable definition of 'defamation of religion' is so apparent that after ten years of passing resolutions, neither the HRC nor the U.N.G.A. has ventured to undertake the task.").

482 U.N. GAOR, 71st Sess., supra note 474.

${ }^{483} I d$. 49.

${ }^{484} I d$. $\mid 57$.

${ }^{485}$ Ministerial Conference on Strengthening Marriage and Family Institution, supra note 189.

${ }^{486}$ OIC Res. No. 1/1-F, 11 (Feb. 8-9, 2017).

${ }^{487}$ Rep. of the Seventh Regular Session of the OIC Independent Permanent Human Rights Commission, at 2, OIC Doc. IPHRC-7 (Apr. 19-23, 2015).

${ }^{488} I d$. 
the core" of their human rights agendas and avoid "misconceptions and controversies, which contradict the universal family values." 489

Another notable resolution that emerged from the OIC's first conference on preserving family values welcomed the OIC CFM's earlier action rejecting UNHRC Resolution 32/2 and endorsed the IPHRC's mandate to prepare a "comprehensive study" to refute SOGI rights. ${ }^{490}$ Ministers also took the opportunity to urge the OIC to continue pursuing repeal of all SOGI-related UNHRC resolutions on the basis that sexual orientation has no link to human rights. ${ }^{491}$ The conference's accompanying "Jeddah Declaration" recommended "[c]ategorical rejection of the advocates of homosexuality and of the voices calling on the Member States to recognize in their legislations the rights of those groups as minorities . . .." ${ }^{992}$ A second ministerial conference, under the banner "Empowering the Marriage and Family Institution and Preserving its Values in Member States," is scheduled to be held in Turkey in 2019. ${ }^{493}$ If the outcome of the first meeting is any indication, developing and implementing OIC strategies for opposing SOGI recognition will continue to dominate this agenda.

\section{CONCLUSION}

This article has traced the evolution of the OIC's approach to international human rights law since the organization's inception. As part of this history, the organization has maintained and continues to espouse a relativist approach, as encapsulated by its 1990 Cairo Declaration on Human Rights in Islam. At the same time, the OIC has increasingly attempted to "mainstream" its views as consistent with and embracing of human rights universality. This has proven to be no easy task, particularly in the face of a growing international awareness of SOGI persecution and the need to affirm equality and nondiscrimination protections for the LBGTI community.

The OIC's efforts to protect its vision of "traditional" family values and deny SOGI recognition have forced it to move from an abstracted and generalized endorsement of universality to a more granular response. This shift has betrayed a rejection of the obligations associated with upholding universality when situated in the context of actual practice. As demonstrated above, where the OIC's revisionist and narrow framing of human rights

${ }^{489} I d$. at 8,42 .

${ }^{490}$ OIC Res. 3/1-F, pmbl. (Feb. 8-9, 2017). Here too, the resolution's language betrays the predetermined outcome of the IPHRC SOGI study. See supra notes 415-16 and accompanying text (noting the IPHRC already deemed "so-called" sexual orientation unsuitable for rights protection); see Blitt, supra note 463 (providing a critical assessment of the IPHRC's SOGI study).

${ }^{491}$ OIC Res. 3/1-F, ๆ 5 (Feb. 8-9, 2017).

${ }^{492}$ OIC, Jeddah Declaration Issued by the First OIC Ministerial Conf. on Marriage and Family Inst. Empowerment and Value Pres. in Member States, | 6, (Feb. 8-9, 2017).

${ }^{493}$ OIC, Final Report: "Towards an OIC Approach to Empowerment and Values Preservation of the Marriage and Family Institution in Member States,” OIC Doc. OIC/1stFMC/2017/REP./FINAL, q 17 (Feb. 8-9, 2017). 
universality is exposed as deficient, the organization is quick to fall back on its longstanding relativist rejoinder that places its own vague religious doctrine ahead of the international human rights obligations owed by its member states. The same pattern is manifested in the IPHRC, the OIC's newly minted "independent" human rights commission.

The OIC's underlying approach identified here builds on and reinforces similar findings drawn from a previous study of the organization's treatment of women's rights. ${ }^{494}$ This, in turn, confirms that the challenge mounted by the OIC against an authentic and purposive interpretation of human rights universality is concerted and deeply problematic. Like its approach to women's rights, where the OIC attempts to justify its SOGI-related redlines that digress from international equality and nondiscrimination norms, it characterizes any applicable human rights obligations as non-universal and thus non-obligatory. And where this stance becomes untenable, the OIC-together with its vassal the IPHRC - contests that such rights are simply incompatible with its own nebulous interpretation of sharia. As demonstrated above, the validity of this approach is premised, among other things, on a faulty interpretation of the VDPA that distorts the substance of universality and its ensuing state obligations. It also hinges on accepting the OIC's interpretation of sharia norms as definitive.

Even if one subscribes to the view that human rights norms in the context of SOGI are not "fully ripened," the OIC's position-outright rejection of the possibility of protection-is antithetical to the very idea of human rights, and arguably to Islam as well. As An-Na'im has concluded in the context of protection for religious minorities, "no cultural relativist argument may be allowed to justify derogation from the basic obligation to uphold and protect the full human rights of religious minorities, within the Islamic or any other cultural context." ${ }^{955}$ The same can be said in the context of SOGI protection. Indeed, the international human rights framework has confirmed as much, albeit with insufficient directness. Hila Jilani's observations on the possibility of rejecting or denying protection against discrimination and violence based on SOGI are apropos:

[such a position] is neither useful nor . . . prudent as a policy for any government that claims the commitment to human rights and to the promotion and protection of human rights. It is also rather difficult and not convincing when culture and tradition are used as a shield for the failure to fulfill the obligation to protect from human rights violations ... There are no notions of responsibility that allow governments and

${ }^{494}$ See Blitt, supra note 1.

495 Abdullah A. An-Na'im, Religious Minorities Under Islamic Law and the Limits of Cultural Relativism, 9 HUM. RTS. Q. 1, 18 (1987). 
duty-bearers to...hold out that responsibility and hold out that protection selectively. ${ }^{496}$

For all its advocacy, the OIC's interpretation of Islamic religious norms also is not universally shared by Muslims everywhere. Despite the organization's pretensions to the contrary, it is but one voice purporting to represent Islamic norms. ${ }^{497}$ There remains a strong claim that the organization even distorts the true essence of Islam and the actual requirements of sharia. ${ }^{498}$ Nevertheless, as Moosa has remarked, "[w]hether one calls it progressive Islam, critical Islam, or critical traditionalism, they are far from being established intellectual discourses and in all honesty they are at their mere infancy ... What is doubtless is that the critique of outdated orthodox paradigms of interpretation requires viable alternatives." 499

More immediately, setting aside the actual viability of this "progressive" approach, the OIC continues to formally represent over 50 member states at the UN and thus flexes an unmatched level of access and influence, including a sizable and constant presence on the UNHRC. The reality remains that this outsize influence dominates the narrative on Islam far beyond the voice of any academic, activist or NGO. More importantly, it colors not only the debate around rights but their substance as well. Mindful of these realities, criticism of the OIC's positions should not be interpreted as denigration of the Muslim faith. By the same token, the organization should not be permitted to deflect such criticism by brandishing the specter of Islamophobia against its critics. Permitting it to do so only feeds the narrative that its policies undercutting equality and non-discrimination do in fact embody the collective view of nearly two billion Muslims.

496 Panel Discussion Sexual Orientation and Gender Identity, supra note 378. Jilani's comments begin at approximately 2:14:00. Id.

497 Other groups have similarly claimed a monopoly on speaking in Islam's name. See e.g. Wajahat Ali, I Talked to Zionists-Then I was Disinvited by a Major Muslim Group, ATLANTIC (May 30, 2018), https://www.theatlantic.com/politics/archive/2018/05/i-talked-to-zioniststhen-i-wasdisinvited-by-a-major-muslim-group/561575/ (asking "How can the [Islamic Society of North America's] 'unifying' position-whatever it is-represent the diverse viewpoints of 1.7 billion Muslims? . . . What happens if someone simply disagrees with them, or has a different interpretation of these values?"); see also Hardtalk: Interview with Ed Husain, BBC NEWS, https://www.bbc.co.uk/programmes/w3cswjdz (last visited Nov. 21, 2018) (calling on moderate Muslims to reclaim their religion from extremists such as Islamic State, describing it as "a battle for the interpretive soul of Islam.”).

${ }^{498}$ In addition to the specific instances discussed herein, there is a wealth of analysis on this issue. See, e.g. Erurk, supra note 37, ๆ 60; ABDUllaH AHMED AN-NA'IM, ISLAM AND THE SECUlAR STATE: Negotiating the Future of Shari'A (2008); Mohammad Hashim Kamali, Freedom of EXPRESSION IN ISLAM, (1997); see also Javaid Rehman \& Eleni Polymenopoulou, Is Green a Part of the Rainbow? Sharia, Homosexuality, and LGBT Rights in the Muslim World, 37 FORDHAM INT'L L.J. 1 (2013).

${ }^{499}$ Ebrahim Moosa, Foreword, in Adis DuderiJA, The ImPeratives of Progressive IsLAM (2017) supra note 445 , at xiv-xv (2017). 
Ultimately, allowing the OIC's positions to be perpetuated without a more systematic and concerted response contributes to actively obstructing international progress in this area, triggering delays, weakening consensus and most troublingly, risks exposing individuals and communities to ongoing rights violations, including violence and death. In an effort to begin advancing this concerted response, advocates and policymakers are advised to take the following measures.

First, at the United Nations, continue to renew and build support for the mandate of the independent expert on SOGI. Specifically, seek to incorporate SOGI-related reporting obligations and data collection into other relevant special procedures mandates and treaty bodies, as well as into the UNHRC's Universal Period Review ("UPR") process and the UN's Sustainable Development Goals. This can begin by dialoging with states abstaining 500 or opposing key votes on SOGI, protection of the family, and related measures. Working to build greater understanding with these states can enhance clarity around international human rights norms relating to SOGI-based protections as well as with the shortcomings inherent in narrowly defining those families entitled to international protection. Plainly, each state that shifts its position away from opposition or abstention serves to further attenuate the OIC's claimed absence of consensus around SOGI recognition. Therefore, this engagement should be designed to vigorously and consistently communicate detailed information rebutting OIC arguments and concerns, including highlighting their internal inconsistencies and incompatibilities with international human rights law. This agenda should also be integrated into multilateral fora as well as bilateral relations.

At the same time, building support for the mandate of the independent expert on SOGI should not be restricted to making demands of others. Rather, supportive states must demonstrate their individual commitments to SOGIbased rights. Accordingly, states endorsing the SOGI mandate should move to extend to the independent expert open invitations to undertake country visits, opportunities to comment on draft legislation, and be responsive to any communications or inquiries sent by the expert. Similarly, these states should continue or begin providing detailed reporting information on SOGI-based discrimination and related issues in their own countries in the context of other UN human rights mechanisms and mandates, as well as within relevant Sustainable Development Goal ("SDG”) forums.

Second, moderate voices within the OIC should be supported, while also taking steps to lessen the organization's impact within the UN's human rights mechanisms. OIC states that have opposed or abstained from OIC-backed IHRL measures at the UN, such as Albania, should be recognized for the potentially moderating influence they may have on the organization's internal deliberations. Such states can be encouraged to generate OIC moderation from

${ }^{500}$ In the past, abstaining states have included Botswana, Ghana, India, South Africa, Namibia, the Philippines, Hungary, Georgia, Mexico, and the Former Yugoslav Republic of Macedonia. 
the inside. For example, they can initiate amendments to internal OIC human rights-related resolutions and take steps to restrain policy positions sought at the UN. These moderates can also work to promote internal clarifications concerning the nature of IHRL and urge the organization's positions to better reflect the reality of diversity within Islam (and among member states), particularly as it relates to "alternate" conceptualizations of sharia being developed by Muslim jurists, scholars, and activists. Here, positive measures including trade and other incentives can also be used to signal support as well as cultivate additional potential state partners.

Together with this, states and NGOs alike should actively oppose OIC efforts to install sympathetic members within the UN's human rights infrastructure in favor of candidates more inclined to embrace the universality of IHRL. Among other things, concerned NGOs and states can place greater emphasis on the fact that when electing members to the UNHRC, states are obligated to "take into account the contribution of candidates to the promotion and protection of human rights and their voluntary pledges and commitments made thereto." ${ }^{01}$ In the same vein, states and NGOs alike need to reassess whether cooperation with the IPHRC or permitting its formal engagement with international and regional human rights mechanisms serve a useful purpose. Given the IPHRC's track record, the commission does not appear to have an independent stance or interest in promoting and protecting human rights. Rather, it merely acts as an echo chamber for OIC policies. Support for human rights universality and integrity within regional human rights mechanisms demands that the IPHRC clearly adopt and endorse (rather than build conflict with) existing IHRL norms, including standing and future UN treaty body general comments. Related to this, the practice of naming and shaming should be made more systematic and more widely disseminated to call attention to the incompatibility of certain OIC positions with IHRL and to seek concrete clarifications from the organization regarding its asserted support for universality.

Third, funding, training, and other workshops should expand to support moderate organizations and initiatives committed to developing and disseminating interpretations of Islam that more fully comport with IHRL; protecting human rights defenders in OIC states; reporting on rights violations in OIC states; and advocating and educating for a fuller understanding of equality, non-discrimination, and tolerance. States and other parties can empower these moderate voices by boosting their international exposure and increasing their opportunities for engagement. For example, LGBTI Muslims, Muslim women, representatives of religious minorities in OIC states, Islamic scholars and others can be invited to participate as witnesses and experts at the UN and other international fora in the context of equality and nondiscrimination-related events. States should also track and support

${ }^{501}$ G.A Res. 60/251, ๆ 8 (Apr. 3, 2006). 
protection of human rights defenders in states opposing SOGI recognition, 502 and continue to raise this issue whether through funding, diplomatic demarches, or other techniques. Likewise, NGOs working within domestic political contexts to educate and inform citizens on human rights, international norms, and alternate interpretations of sharia should be similarly supported as a means of building greater awareness and consensus around the issues.

In the end, abiding the OIC's efforts to dilute the spirit of universality encapsulated in the UDHR's grundnorm that "all human beings are born free and equal in dignity and rights," or to invoke a relativistic, religiously-justified waiver on equality and non-discrimination norms risks legitimizing ongoing rights violations against the LGBTI community and women, among others. More broadly still, the failure to decisively reject and systematically counter such efforts poses a direct threat to the viability of universality and is antithetical to the nearly century-old push to secure a universal human rights framework that recognizes and protects every individual's fundamental human dignity.

\footnotetext{
502 Nick J. Mulé has called attention to the "risky and insecure" position of LGBTQI human rights defenders, and the reality that "while defending others in their communities, themselves face opposition from those within the UN who hold traditional, religious, and culturally based values, as well as a result of state sovereignty and state-sanctioned criminalisation of their gender and sexual diversity." Nick J. Mulé, LGBTQI-Identified Human Rights Defenders: Courage in the Face of Adversity at the United Nations, 26 GENDER \& DEV. 89, 101 (2018).
} 